\title{
HYDROGEOLOGY AND SIMULATION OF GROUND-WATER FLOW IN THE SANDSTONE AQUIFER, NORTHEASTERN WISCONSIN
}

\section{By T.D. Conlon}

U.S. GEOLOGICAL SURVEY

Water-Resources Investigations Report 97-4096

Prepared in cooperation with the

VILLAGE OF LITTLE CHUTE

DARBOY SANITARY DISTRICT \# 1

KIMBERLY WATER WORKS DEPARTMENT

TOWN OF MENASHA SANITARY DISTRICT \#4

KAUKAUNA ELECTRIC AND WATER UTILITIES

WISCONSIN GEOLOGICAL AND NATURAL HISTORY SURVEY

EAST CENTRAL WISCONSIN REGIONAL PLANNING COMMISSION

Middleton, Wisconsin

1998
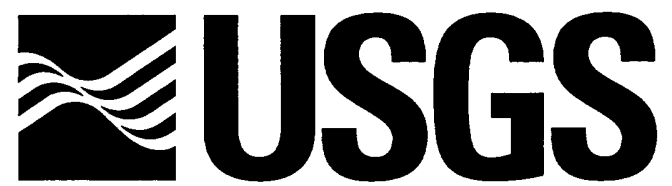

science for a changing world 


\title{
U.S. DEPARTMENT OF THE INTERIOR BRUCE BABBITT, Secretary
}

\author{
U.S. GEOLOGICAL SURVEY \\ Thomas J. Casadevall, Acting Director
}

For additional information write to:

Copies of this report can be purchased from:

District Chief

U.S. Geological Survey

8505 Research Way

Middleton, WI 53562-3581
U.S. Geological Survey

Branch of Information Services

Box 25286

Denver, CO 80225-0286 


\section{CONTENTS}

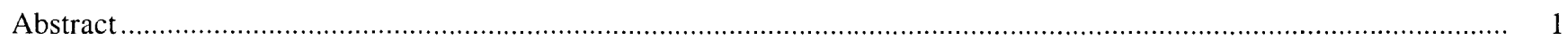

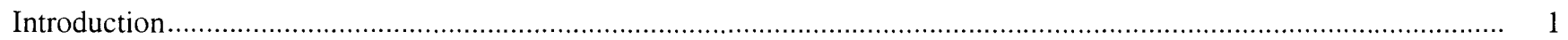

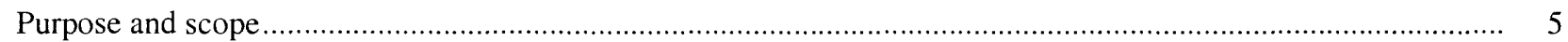

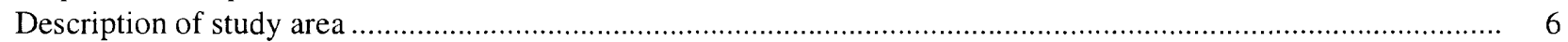

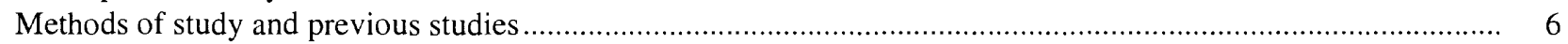

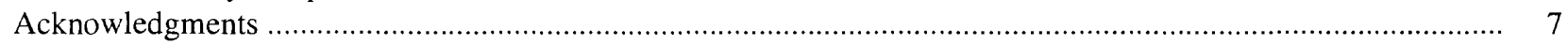

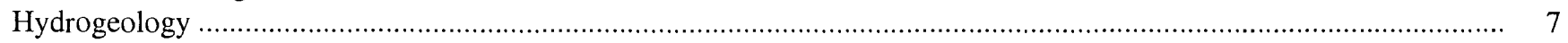

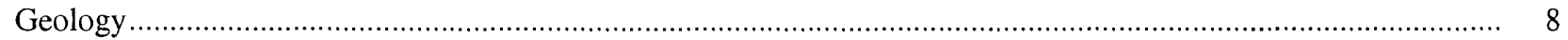

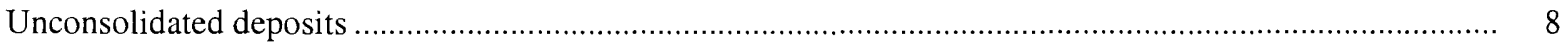

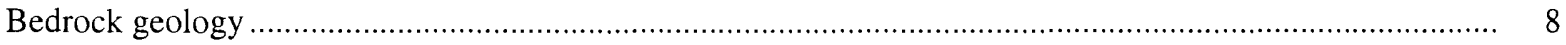

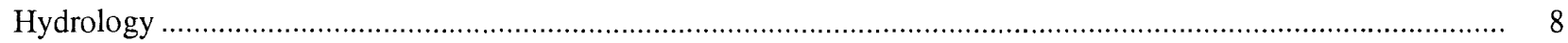

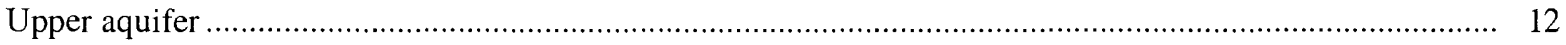

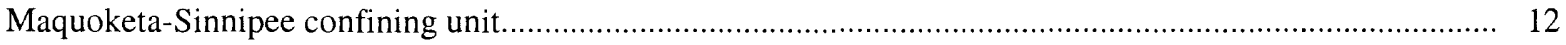

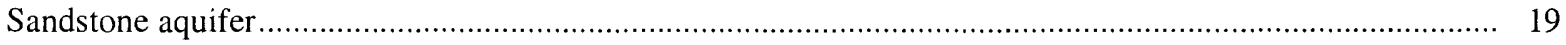

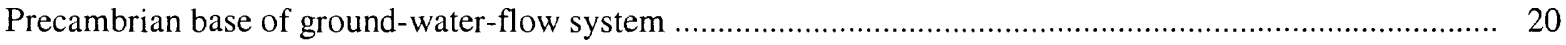

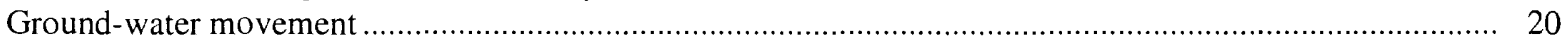

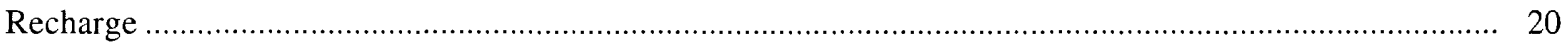

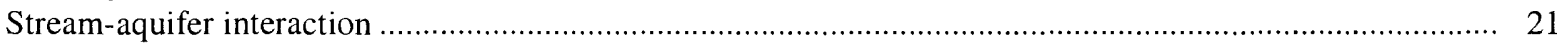

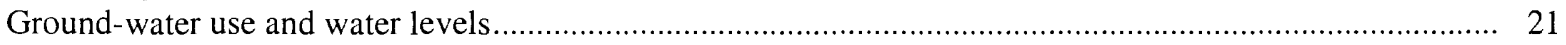

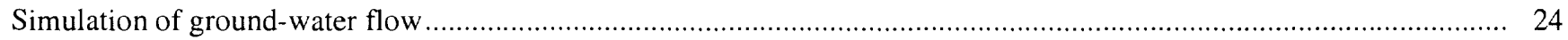

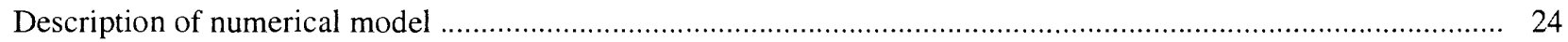

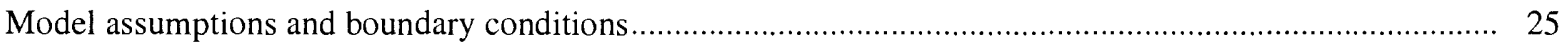

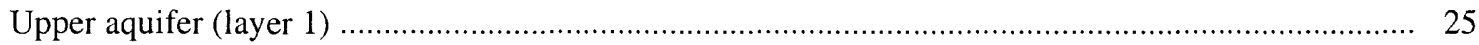

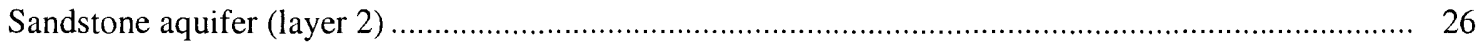

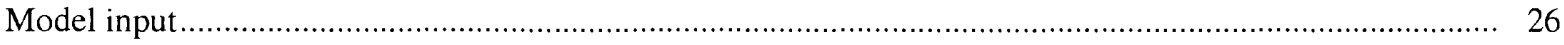

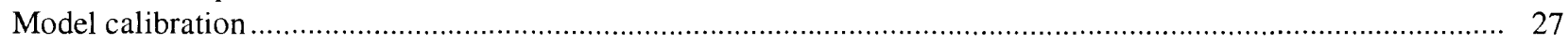

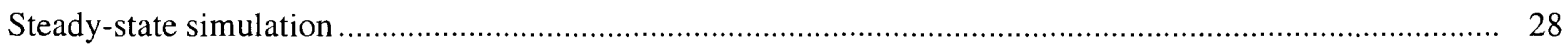

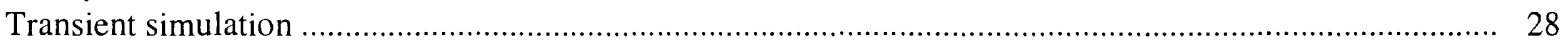

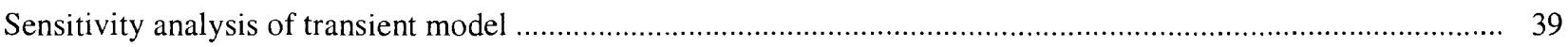

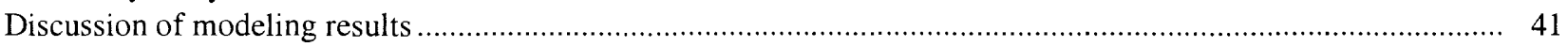

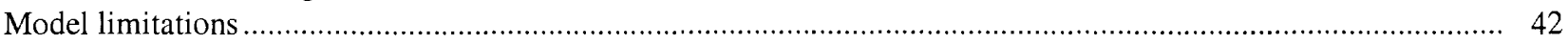

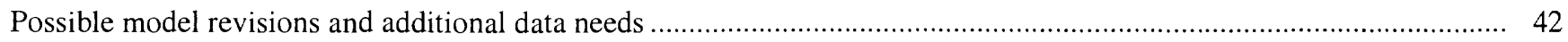

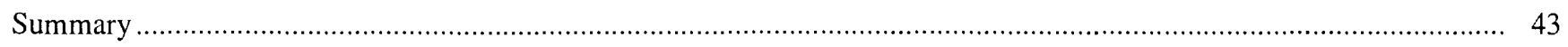

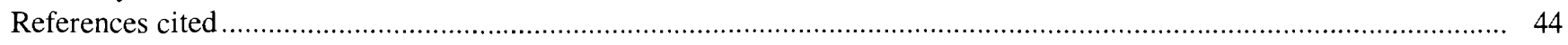

Appendix A. Ground-water withdrawals from the sandstone aquifer in Brown, Fond du Lac, Outagamie, and

Winnebago Counties, northeastern Wisconsin, 1880-1990

\section{FIGURES}

Plate 1. Grid and selected boundaries of the ground-water-flow model and stream gaging stations [plate is in pocket]

Figure 1. Map showing location of study and model areas in northeastern Wisconsin

2A-B. Maps showing:

2A. Potentiometric surface in sandstone aquifer, northeastern Wisconsin, 1957

2B. Potentiometric surface in sandstone aquifer, northeastern Wisconsin, 1990

3. Hydrograph showing water levels and the rate of drawdown in two wells near Fox Cities, northeastern Wisconsin, 1953-95.....

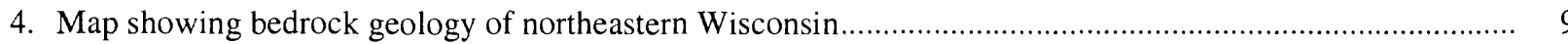


5. Diagram of hydrostratigraphy of northeastern Wisconsin.

6. Generalized hydrogeologic section showing aquifers, confining unit, and ground-water flow, northeastern Wisconsin

7A-D. Maps showing:

7A. Thickness of upper aquifer, northeastern Wisconsin

7B. Thickness of Maquoketa-Sinnipee confining unit, northeastern Wisconsin..

7C. Thickness of sandstone aquifer, northeastern Wisconsin

7D. Altitude of top of Precambrian rock surface beneath sandstone aquifer, northeastern

Wisconsin.

8. Diagrams showing evidence of the confining properties of the Sinnipee Group, northeastern Wisconsin....... 17

9. Graph of ground-water withdrawals from the sandstone aquifer, by (A) county and (B) type of use, northeastern Wisconsin

10. Map showing locations of high-capacity municipal and industrial wells and magnitude of withdrawals from the sandstone aquifer, northeastern Wisconsin ....

11. Map showing simulated predevelopment potentiometric surface in the sandstone aquifer, northeastern Wisconsin.

12A-B. Maps showing:

12A. Simulated potentiometric surface in the sandstone aquifer, northeastern Wisconsin, 1957

12B. Simulated potentiometric surface in the sandstone aquifer, northeastern Wisconsin, 1990

13. Diagram showing simulated water budgets for the sandstone aquifer at predevelopment and 1990, northeastern Wisconsin

14A-B. Maps showing:

14A. Differences between measured and simulated water levels in the sandstone aquifer, northeastern Wisconsin, 1957

14B. Differences between measured and simulated water levels in the sandstone aquifer, northeastern Wisconsin, 1990

15. Hydrographs of measured and simulated water levels at selected sites in northeastern Wisconsin, 1945-90 .. 35

16. Graphs showing sensitivity of simulated heads and streamflow to changes in selected model parameters of the ground-water-flow model for northeastern Wisconsin .....

\section{TABLES}

1. Geographic information system data that were incorporated into the three-dimensional ground-water-flow model of northeastern Wisconsin.

2. Hydraulic properties of aquifers and confining units, northeastern Wisconsin ...

3. Parameter values used in the ground-water-flow model for northeastern Wisconsin

4. Measured and simulated water levels, and root mean square error of simulated water levels for steady-state predevelopment simulation, northeastern Wisconsin

5. Measured and simulated water levels, and root mean square error for transient simulations, 1957 and 1990, northeastern Wisconsin 


\begin{tabular}{|c|c|c|}
\hline Multiply & By & To Obtain \\
\hline inch per year (in/yr) & 25.4 & millimeter per year \\
\hline mile $(\mathrm{mi})$ & 1.609 & kilometer \\
\hline foot $(\mathrm{ft})$ & 0.3048 & meter \\
\hline foot per second $(\mathrm{ft} / \mathrm{s})$ & 0.3048 & meter per second \\
\hline foot per day (ft/d) & 0.3048 & meter per day \\
\hline foot per year $(\mathrm{ft} / \mathrm{yr})$ & 0.3048 & meter per year \\
\hline gallon (gal) & 3.785 & liter \\
\hline gallon per minute (gal/min) & 0.06309 & cubic meter per second \\
\hline gallon per year $(\mathrm{gal} / \mathrm{yr})$ & 3.785 & liter per year \\
\hline million gallons per day $(\mathrm{Mgal} / \mathrm{d})$ & 0.04381 & cubic meter per second \\
\hline square mile $\left(\mathrm{mi}^{2}\right)$ & 2.590 & square kilometer \\
\hline \multicolumn{3}{|c|}{$\begin{array}{l}\text { Temperature, in degrees Fahrenheit }\left({ }^{\circ} \mathrm{F}\right) \text { can be converted to degrees Celsius }\left({ }^{\circ} \mathrm{C}\right) \text { by use of the following equation: } \\
\qquad{ }^{\circ} \mathrm{C}=5 / 9\left({ }^{\circ} \mathrm{F}-32\right) .\end{array}$} \\
\hline
\end{tabular}

Sea level: In this report, "sea level" refers to the National Geodetic Vertical Datum of 1929 (NGVD of 1929)-a geodetic datum derived from a general adjustment of the first-order level nets of the United States and Canada, formerly called Sea Level Datum of 1929. 


\title{
Hydrogeology and Simulation of Ground-Water Flow in the Sandstone Aquifer, Northeastern Wisconsin
}

\author{
By T.D. Conlon
}

\section{Abstract}

Municipalities in the lower Fox River Valley in northeastern Wisconsin obtain their water supply from a series of permeable sandstones and carbonates of Cambrian to Ordovician age.

Withdrawals from this "sandstone aquifer" have resulted in water levels declining at a rate of more than 2 feet per year. The U.S. Geological Survey, in cooperation with the major water utilities in the Fox Cities area, the East Central Wisconsin Regional Planning Commission and the Wisconsin Geological and Natural History Survey, collected hydrogeological data and constructed a quasithree-dimensional, transient ground-water-flow model for use as a tool in assessing the water resources of the sandstone aquifer.

The rocks of the Sinnipee Group and Maquoketa Shale form the Maquoketa-Sinnipee confining unit that separates the sandstone aquifer from the overlying upper aquifer, which consists of unconsolidated deposits and permeable dolomite of Silurian age. The confining unit is present in the eastern part of the study area, but is absent in the western part, where the upper aquifer directly overlies the sandstone aquifer.

The ground-water-flow model simulates water levels in the two aquifers and vertical flow across the confining unit. Streams and lakes are simulated in the upper aquifer as head-dependent boundaries where the confining unit is absent and as constant head boundaries where the confining unit is present. The sandstone aquifer has constant heads assigned to the southern boundary, which is far from the lower Fox River Valley and coincident with a ground-water divide.

The model was calibrated to predevelopment, 1957, and 1990 water levels, and used to simulate steady-state predevelopment conditions and transient conditions from 1880 to 1990 . The trend in simulated water levels over time was sim- ilar to trends in measured water levels. Simulated base flow to streams was within the calculated range of base flow at gaged streams. A groundwater divide that separates westerly ground-water flow to the Wolf River from easterly flow to the lower Fox River Valley and Lake Michigan was simulated.

\section{INTRODUCTION}

The "sandstone aquifer," which consists of permeable sandstone and dolomite strata, is the major aquifer beneath the urban area along the Fox River from Lake Winnebago to Green Bay, Wis. (fig. 1). Industrial and municipal pumping from the aquifer in this area has resulted in declining water levels. Wells withdrawing water from the sandstone aquifer are concentrated in two areas along the Fox River: the Fox Cities area, which is an urban area along the Fox River from Lake Winnebago to the border of Brown and Outagamie Counties, and the Green Bay metropolitan area, where the Fox River flows into the Green Bay area of Lake Michigan. A cone of depression in potentiometric surface of the aquifer beneath the Fox Cities area has merged with the cone of depression in the Green Bay area (fig. 2).

Water levels in the sandstone aquifer have declined and continue to decline at a rate of approximately 2 feet per year (ft/yr) near the Fox Cities (fig. 3). The rate of decline is greater in the Green Bay area, where the greatest ground-water withdrawal occurs. The decline in water levels is of concern to area municipalities that withdraw water to supply commercial, domestic, and industrial users. Continued decline in water levels in the aquifer may result in increased cost of pumping and potential water-quality problems as water deeper in the aquifer, which may contain high concentrations of dissolved solids, is withdrawn. To address these concerns, the U.S. Geological Survey (USGS), in cooperation with the major municipal ground-water users in the Fox Cities area, the East Central Wisconsin Regional Planning Commission and the Wisconsin Geological and Natural History Survey, col- 

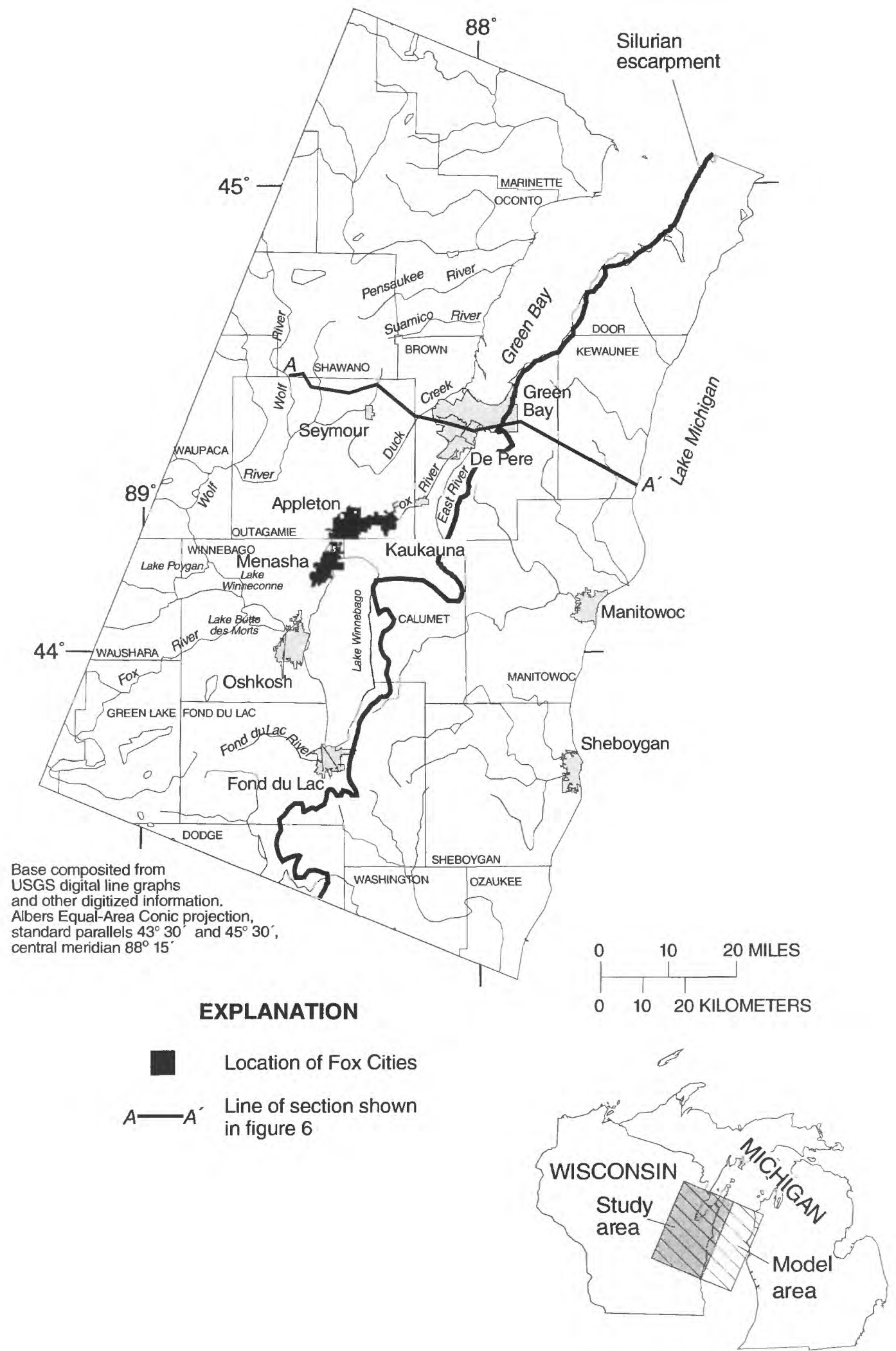

Location of model and study areas

Figure 1. Location of study and model areas in northeastern Wisconsin. 


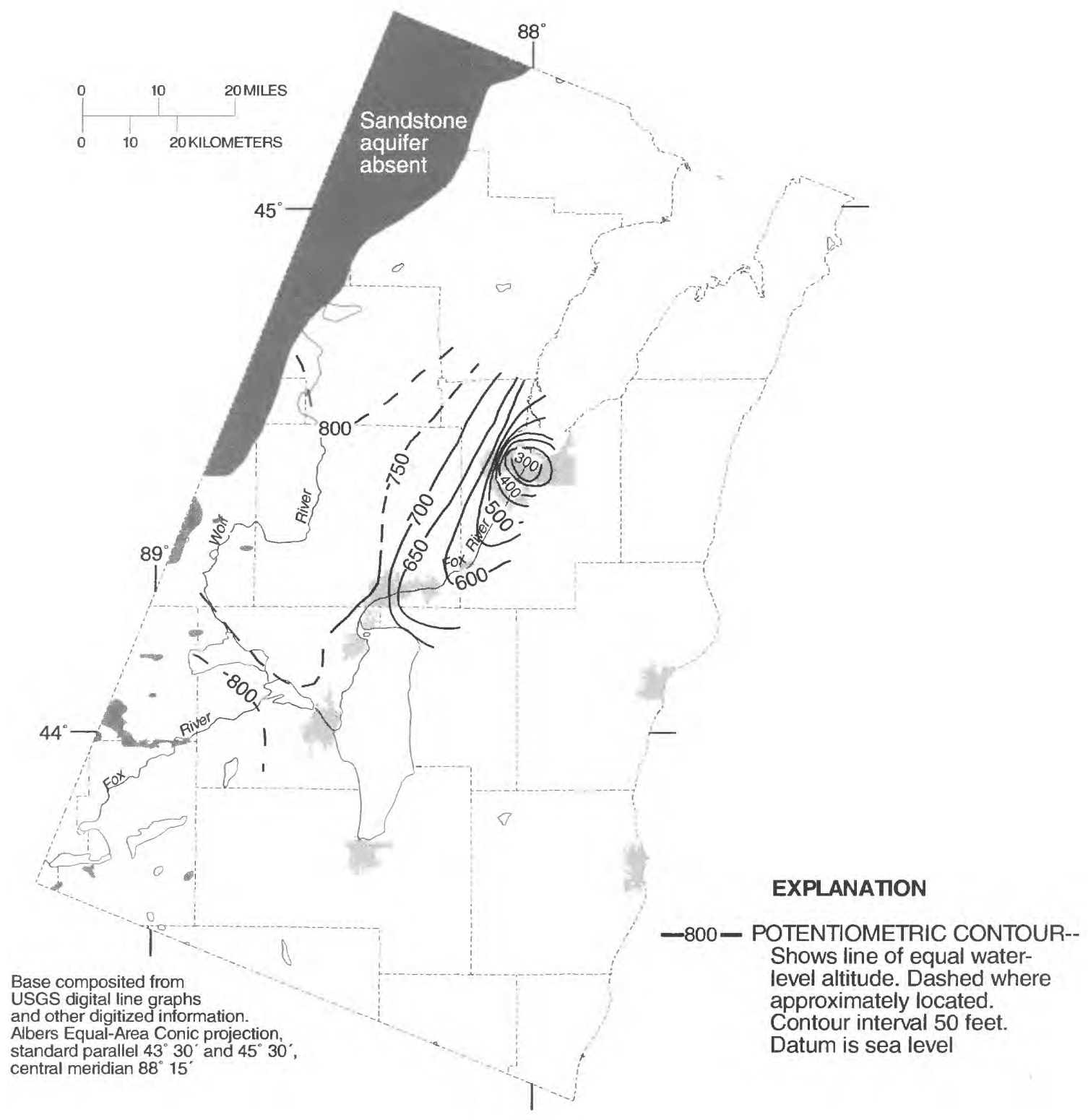

Figure 2A. Potentiometric surface in sandstone aquifer, northeastern Wisconsin, 1957. 
B. Potentiometric surface in 1990

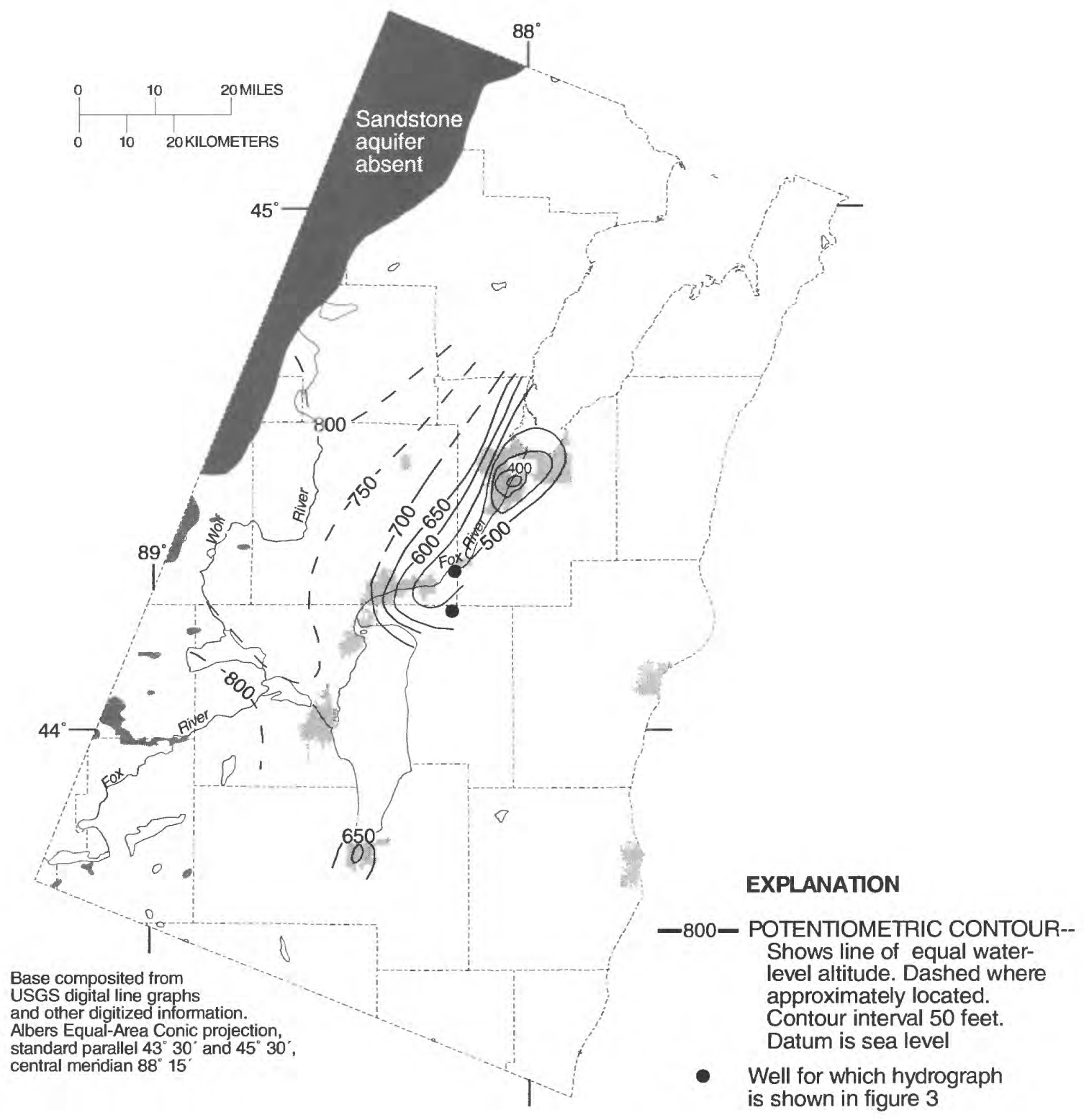

Figure 2B. Potentiometric surface in sandstone aquifer, northeastern Wisconsin, 1990 - Continued. 
lected hydrogeologic data from 1991 to 1995 and developed a ground-water-flow model to improve the understanding of the hydrogeology of the ground-water system.

The goals of the study were to compile hydrologic data of aquifer and confining units, water-use data, and water-level data to conceptualize the groundwater-flow system. This information was then used to construct and calibrate a ground-water-flow model for use as a tool to (1) test the conceptualization of the ground-water system in northeastern Wisconsin, and (2) simulate possible future ground-water withdrawal alternatives and delineate resulting flowpaths and contributing areas of wells.

\section{Purpose and Scope}

This report describes the hydrogeology of the sandstone aquifer and a quasi-three-dimensional ground-water-flow model of northeastern Wisconsin. The model simulates predevelopment conditions and historical responses to ground-water withdrawals from 1880 to 1990 . The description of the hydrogeologic framework of the area is based on material presented in Krohelski (1986), Emmons (1987), and Mandle and Kontis (1992).
The modeling effort in this study differs from previous modeling efforts in the area in that (1) the resolution of the model is greater than that in previous models, (2) model boundaries are extended to the south to include the pumping center near Fond du Lac and to the west to include the Wolf River or the western extent of the sandstone aquifer, (3) the upper aquifer which includes unconsolidated deposits, is simulated as an active unit, and (4) the data were compiled in a geographic information system (GIS) so that the data base can be updated and used for enhancements to the model as new or revised hydrologic information becomes available. Although the unconsolidated deposits and Silurian rock were simulated as an aquifer, the focus of the study is limited to the underlying sandstone aquifer.

The data required to develop the ground-waterflow model were available from previous studies (Krohelski, 1986; Emmons, 1987), in which the geologic framework and hydrology of the area were described. Data collection for this study was limited to measurement of water levels in 1990, compilation of additional well logs (to improve hydrostratigraphic control in the Fox Cities area) and 1990 water-use information, and borehole packer tests to determine the hydraulic characteristics of a confining unit above the sandstone aquifer.

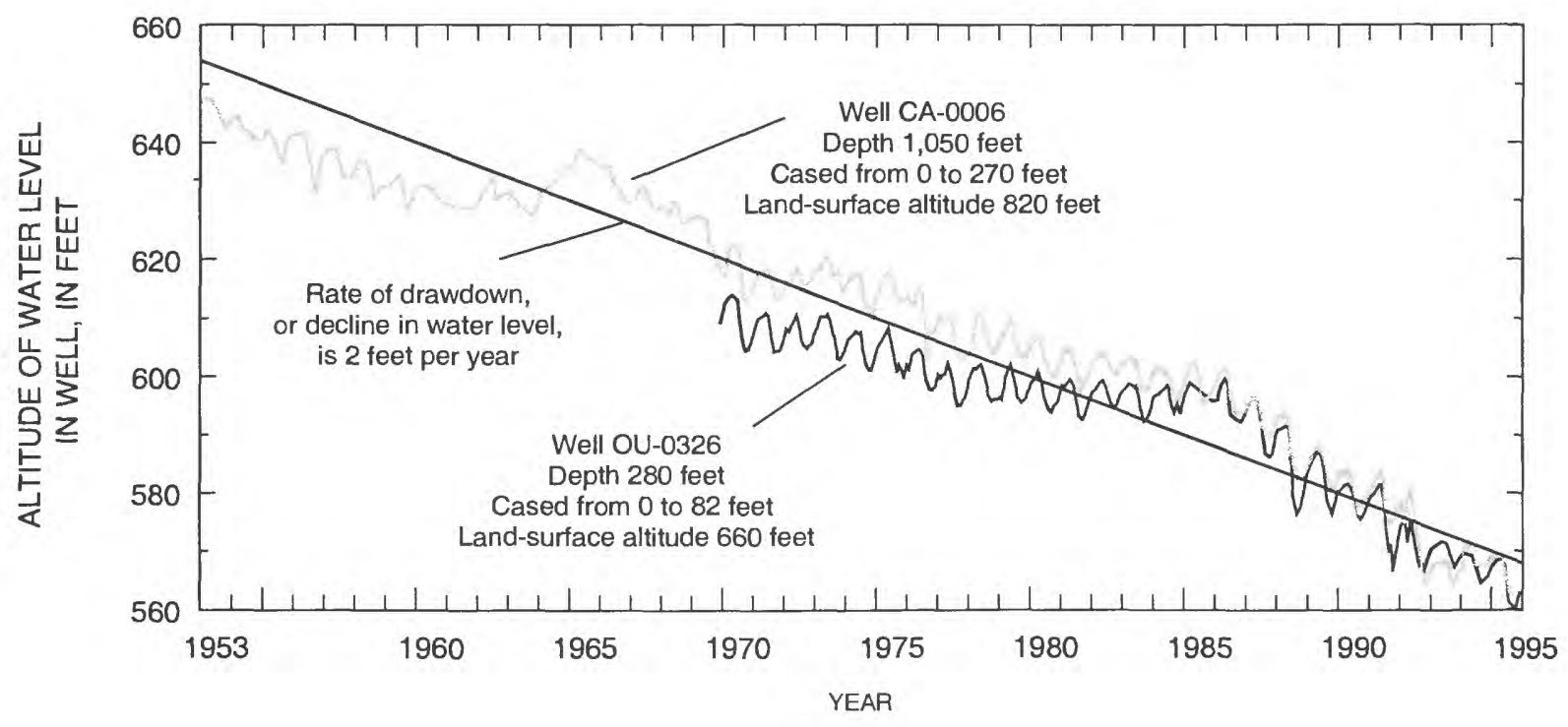

Figure 3. Water levels and the rate of drawdown in two wells near Fox Cities, northeastern Wisconsin, $1953-95$. 


\section{Description of Study Area}

The study area includes all or parts of 22 counties in northeastern Wisconsin (fig. 1). The land area of the study area is approximately 10,000 square miles $\left(\mathrm{mi}^{2}\right)$. The area simulated in the ground-water-flow model (fig. 1) is larger-approximately $16,000 \mathrm{mi}^{2}$-in order to reduce the effect of the model boundaries on simulations within the study area. The study area extends to the north of Green Bay to include the effect of pumping in the Green Bay area. The western extent was chosen to include the Wolf River and upper Fox River, two large rivers and ground-water discharge areas in the study area. The study area extends south of Fond du Lac, a pumping center of less magnitude than the Fox Cities or Green Bay area.

The major topographic features (fig. 1) include the Silurian escarpment which is a dolomite ridge along the eastern shore of Lake Winnebago, east of the lower Fox River Valley between Lake Winnebago and Green Bay and along the eastern shore of Green Bay; the FoxWolf Rivers lowlands which extend along the rivers from the southwestern and northwestern corners of the study area to Green Bay; and a hilly area between the lower Fox River Valley and the Wolf River. Most streams east of the Silurian escarpment drain eastward to Lake Michigan. Streams in the western half of the study area drain to the Fox and Wolf Rivers, before flowing into Green Bay. Streams in the northwestern part of the study area drain eastward to Green Bay. The altitudes of Lake Winnebago and Green Bay are 747 and $577 \mathrm{feet}$ (ft), respectively. The altitude of land reaches approximately $1,100 \mathrm{ft}$ in the northwestern part of the study area and along the Silurian escarpment.

Agriculture constitutes the largest area of land use in the study area (Robertson and Saad, 1996, p. 17-18). Urban land use is limited to the Fox Cities area, Green Bay metropolitan area, Oshkosh, Fond du Lac, Manitowoc, Sheboygan, and other smaller communities. The remaining land is wetlands, in the western part of the study area and east of the Silurian escarpment, and forests scattered throughout the study area.

\section{Methods of Study and Previous Studies}

Hydraulic characteristics for aquifers and the confining unit in the study area were compiled from previous studies. The hydrogeology of the area has been described in several earlier county or multicounty studies. The USGS has published individual reports that describe the hydrogeology of Brown (Drescher, 1953), Outagamie (LeRoux, 1957), Winnebago (Olcott, 1966), and Fond du Lac (Newport, 1962) Counties. In 1957, the city of Green Bay stopped withdrawing water from the sandstone aquifer and began using Lake Michigan as its water supply. The recovery of water levels in the Green Bay area was documented by Knowles (1964). The water use and options for water supply in the metropolitan area around Green Bay were discussed by Knowles and others (1964). The hydrogeology and geochemistry of the sandstone aquifer was studied as part of a multistate assessment of the Cambrian-Ordovician aquifer system in the northern Midwest (Siegel, 1989; Young, 1992a, 1992b).

Recent studies used numerical modeling to improve the understanding of the hydrogeology and address the concerns of declining water levels in the aquifer due to pumping. Krohelski (1986) simulated ground-water flow in the sandstone aquifer in Brown County. Emmons (1987) simulated ground-water flow in an area that included the Green Bay and Fox Cities areas using a coarse grid finite-difference model. Ground-water flow in the sandstone aquifer was simulated as part of the multistate assessment of the Cambrian-Ordovician aquifer system in the northern Midwest (Mandle and Kontis, 1992).

As part of this study, drillers' construction reports for more than 500 domestic and municipal wells were compiled and analyzed to improve delineation of the glacial and bedrock geology. Boreholes were geophysically logged when possible to help identify geologic units. Borehole packers were installed in wells open to the Sinnipee Group to isolate borehole intervals and determine the hydraulic properties of the confining unit. Water-use information for the period 1980-85 was obtained from the USGS Water-Use Data System (WUDS). Water use information prior to 1980 was compiled from data sets used in the study by Mandle and Kontis (1992). Water use information for 1990 was obtained from WUDS and the major water users in the study area.

The data base for this study is designed to be easily updated and graphically displayed. The use of a GIS is essential to manage and display the large amount of data needed for the current model and to meet the requirement that the model be updated as information becomes available. GIS programs (Kernodle and others, 1995 , p. 6-11) were used to create the finite-differ- 
ence ground-water-flow model grid described later in this report. The programs also were used to move the data between the GIS data base and the model grid. Thickness and altitude maps for aquifers and confining units were available from previous studies and were digitized into the GIS. The GIS creates a continuous surface from the digitized contours using Delaunay triangulation (Environmental Systems Research Institute, 1991 , p. 2-11). The values were assigned to a node at the center of a grid cell within the GIS equivalent to the model grid using bivariate linear interpolation (Environmental Systems Research Institute, 1991, p. 2-19). GIS data that were used directly in the model are listed in table 1.

The projection of the model grid and all GIS data used in the model is an Albers Conic Equal-Area projection based on the Clarke 1866 sheroid, with parallels of lat $43^{\circ}$ and $30^{\prime} \mathrm{N}$. and $45^{\circ}$ and $30^{\prime} \mathrm{N}$., a central meridian of long $88^{\circ}$ and $15^{\prime} \mathrm{W}$., a Y-coordinate origin of lat $43^{\circ} \mathrm{N}$. and no X-or Y-coordinate offsets (false easting or northing). Units are in feet. The model grid has a 23 degree rotation around the grid origin of X-coordinate $-31692.4 \mathrm{ft}$ and Y-coordinate 867201.9 in the Albers projection described above.

\section{Acknowledgments}

The author wishes to thank Harlan Kiesow of the East Central Wisconsin Regional Planning Commis- sion and Kenneth Jaworski of the Brown County Regional Planning Commission for their assistance in compiling ground-water use projections and convening meetings with staff of water utilities to discuss the study. William Batten, formerly of the U.S. Geological Survey, and Douglas Yeskis, U.S. Environmental Protection Agency, are acknowledged for providing some of the well data concerning the hydraulic properties of the Sinnipee Group. Special appreciation is extended to James Krohelski, of the U.S. Geological Survey for his generous advice and constructive criticism during the study.

\section{HYDROGEOLOGY}

An understanding of the hydrogeology of northeastern Wisconsin is necessary to describe the aquifer conditions in the area and to develop a numerical model for simulating ground-water flow. Ground water is found in the pores and fractures of the unconsolidated deposits and rock in the study area. Because several other studies of the geology of the study area have been published, geology is only briefly described in this report. Emphasis is placed on how the geologic units are assigned to aquifers and confining units. Evidence of the confining properties of the rocks of the Sinnipee Group is presented.

Table 1. Geographic information system data that were incorporated into the three-dimensional ground-water-flow model of northeastern Wisconsin

[WGNHS, Wisconsin Geological and Natural History Survey; NMD, USGS National Mapping Division; DLG, Digital Line Graphs; DEM, Digital Elevation Model; USGS, U.S. Geological Survey; GWSI, Ground Water Site Inventory]

\begin{tabular}{|c|c|c|}
\hline Data type & Source scale & Source \\
\hline Geology & $1: 500,000$ & $\begin{array}{l}\text { WGNHS, 1981; G.L. Smith., Lawrence University, written } \\
\text { commun., } 1991\end{array}$ \\
\hline Hydrography & $1: 2,000,000$ & NMD, DLG \\
\hline Topography & $1: 250,000$ & NMD, DEM \\
\hline Aquifer, physical properties & $1: 250,000$ & USGS (Krohelski, 1986; Emmons, 1987) \\
\hline Wells & $1: 24,000$ & USGS, GWSI \\
\hline Finite-difference model grid & Computer generated & USGS \\
\hline
\end{tabular}




\section{Geology}

The unconsolidated deposits and rock beneath the study area were influenced by two important geologic events: the advance of the continental glaciers which left behind a variety of unconsolidated deposits and shaped the landscape; and the subsidence of the Michigan Basin to the east, which resulted in the deposition and preservation of a sequence of sedimentary rocks of Cambrian to Devonian age.

\section{Unconsolidated Deposits}

Unconsolidated deposits of Quaternary age overlie the bedrock and consist of sediments of glacial, alluvial and lacustrine origin. Glacial deposits cover the bedrock in most of the study area. Between 25,000 and 9,500 years ago, two lobes of the Wisconsinan Glaciation covered the area: the Green Bay Lobe covered the area west of the Silurian escarpment (fig. 1), and the Lake Michigan Lobe glaciated areas east of the escarpment. Types of glacial deposits in the study area include tills consisting of a mixture of gravel, sand, silt, and clay; outwash, consisting of sand and gravel; and glaciolacustrine deposits, consisting of silt and clay. Recent alluvial and lacustrine deposits are found in river valleys and lakes, respectively, and consist of fine-grained deposits of sand, silt, and clay. Farrand and others (1984) report that lacustrine silt and clay are present in the Fox and Wolf River valleys, clayey till is present east of the Silurian escarpment, and silty and sandy tills are present west of the Green Bay area of Lake Michigan. In the southern part of the study area, the till is sandy with clayey or silty lenses (Linebeck and others, 1983). Scattered isolated outwash deposits are also found within the study area. The unconsolidated deposits are discussed in more detail by Linebeck and others (1983), Farrand and others (1984), Need (1985), Krohelski (1986), and Clayton and others (1991).

\section{Bedrock Geology}

Crystalline rock of Precambrian age underlies the sedimentary rock in most of the study area and directly underlies the glacial deposits in the northwestern part of the study area (fig. 4). Sedimentary rock beneath the study area ranges in age from Cambrian to Devonian (figs. 4 and 5). The sedimentary rock, consisting of sandstone, shale, and dolomite (fig. 5), gently dips at about 30 to 40 feet per mile (ft/mi) to the east toward the Michigan Basin (fig. 6). With the exception of the Maquoketa Shale, which is predominantly shale, most rock units consist of sandstone and dolomite. Erosion and glaciation have leveled the bedrock surface so that younger rocks are found in the eastern part of the study area. The sedimentary rock is discussed in more detailed by Krohelski (1986), Young (1992b), and Mai and Dott, Jr. (1985).

\section{Hydrology}

The unconsolidated deposits and sedimentary rock described above have been grouped by many authors into aquifers, hydrogeologic units that will yield a usable quantity of water to a well, and confining units, hydrogeologic units that yield little water and restrict the movement of water into or out of adjacent aquifers. Previous studies have considered the unconsolidated deposits and the overlying dolomite of Silurian age as aquifers, and the Maquoketa Shale as a confining unit, regionally. The Precambrian crystalline rock yields little water and is generally considered to be the base of the ground-water-flow system. Previous studies have differed mainly in the manner in which the sedimentary rocks beneath the Maquoketa Shale were grouped. The sedimentary rock beneath the Sinnipee Group (fig. 5) has been recognized either as one aquifer or as several aquifers separated by confining units. The Sinnipee Group has been considered both as a confining unit and as an aquifer.

Previous studies in the Green Bay area considered the sedimentary rock underlying the Sinnipee Group as the sandstone aquifer, and the Sinnipee Group as a low yielding aquifer (Drescher, 1953, p. 9; Knowles, 1964, p. 2; Knowles and others, 1964, p. 7 and 54). In the Fond du Lac area, the sedimentary rock beneath the Sinnipee Group was reported to be waterbearing, and the Sinnipee Group was reported to be less permeable and to contain layers that restrict the vertical movement of ground water (Newport, 1962, p. 21). In Outagamie County, the rocks beneath the Sinnipee Group were considered water-bearing (LeRoux, 1957, p. 7). The Sinnipee Group in Outagamie County was reported to yield a small amount of water (LeRoux, 1957 , p. 12). In Winnebago County, the Sinnipee Group is considered an unproductive water-bearing unit and the sedimentary rock underlying the Sinnipee 


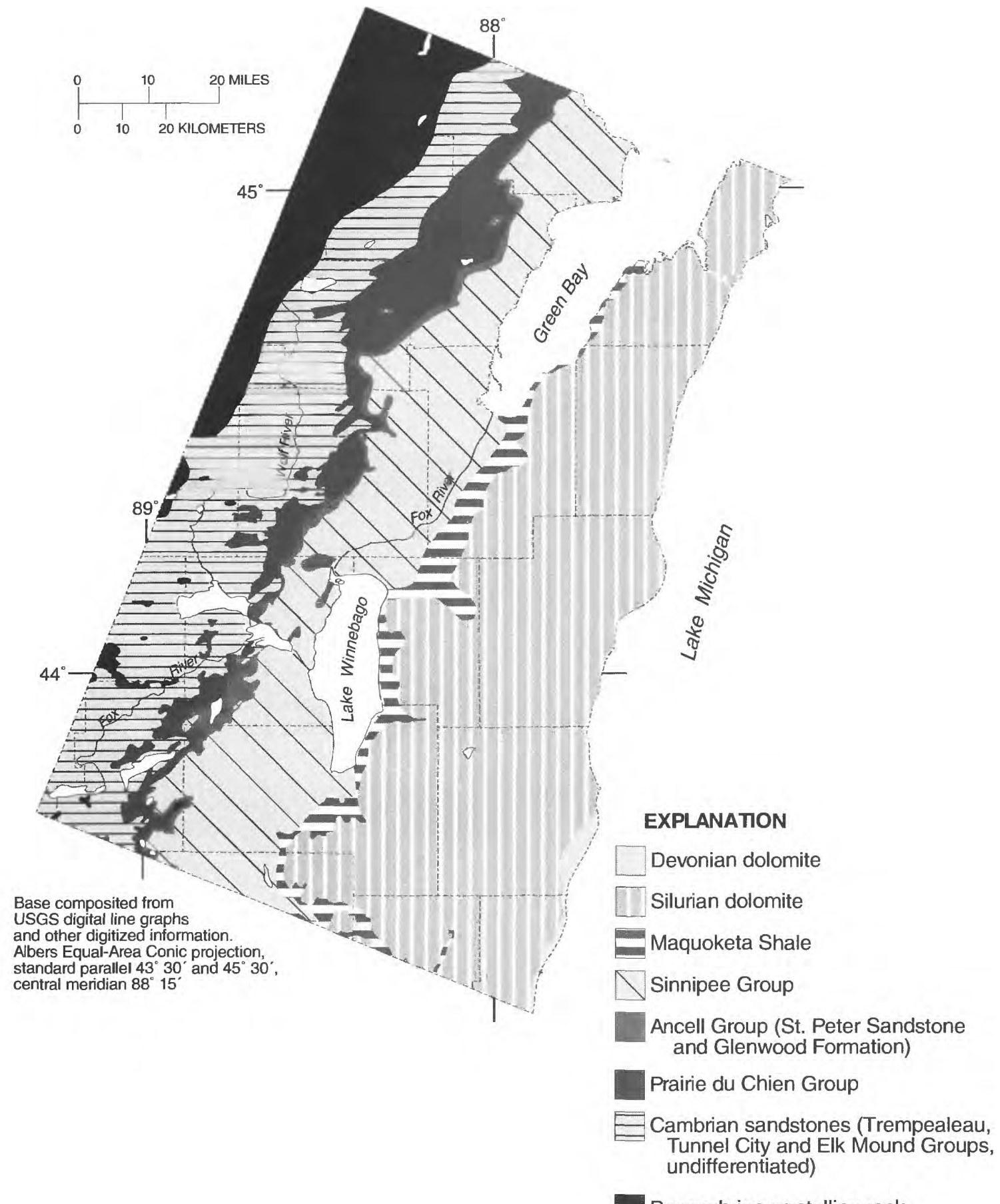

Precambrian crystalline rock

Figure 4. Bedrock geology of northeastern Wisconsin. 


\begin{tabular}{|c|c|c|c|c|}
\hline $\begin{array}{c}\text { Geologic } \\
\text { age }\end{array}$ & & $\begin{array}{c}\text { Geologic } \\
\text { unit }\end{array}$ & $\begin{array}{c}\text { Hydrologic } \\
\text { unit }\end{array}$ & $\begin{array}{l}\text { Principal } \\
\text { lithology }\end{array}$ \\
\hline Quaternary & \multicolumn{2}{|c|}{ Unconsolidated deposits } & \multirow{3}{*}{$\begin{array}{l}\text { Upper aquifer } \\
\text { (model layer } 1)\end{array}$} & $\begin{array}{l}\text { Unconsolidated sediments } \\
\text { of gravel, sand, silt, and } \\
\text { clay }\end{array}$ \\
\hline Devonian & \multicolumn{2}{|c|}{ Devonian dolomite } & & Dolomite, shaly \\
\hline Silurian & \multicolumn{2}{|c|}{ Silurian dolomite } & & Dolomite \\
\hline \multirow{5}{*}{ Ordovician } & \multicolumn{2}{|c|}{ Maquoketa Shale } & \multirow{2}{*}{$\begin{array}{l}\text { Maquoketa-Sinnipee } \\
\text { confining unit } \\
\text { (not modeled as } \\
\text { layer) }\end{array}$} & Shale, dolomitic \\
\hline & \multicolumn{2}{|c|}{ Sinnipee Group } & & Dolomite and shale \\
\hline & \multirow{2}{*}{ 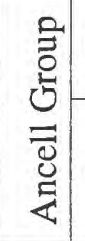 } & Glenwood Formation & \multirow{6}{*}{$\begin{array}{c}\text { Sandstone aquifer } \\
\text { (model layer 2) }\end{array}$} & Dolomite, shaly \\
\hline & & St. Peter Sandstone & & Sandstone \\
\hline & \multicolumn{2}{|c|}{ Prairie du Chien Group } & & Dolomite, cherty \\
\hline \multirow{3}{*}{ Cambrian } & \multicolumn{2}{|c|}{ Trempealeau Group } & & Sandstone \\
\hline & \multicolumn{2}{|c|}{ Tunnel City Group } & & Sandstone \\
\hline & \multicolumn{2}{|c|}{ Elk Mound Group } & & Sandstone \\
\hline Precambrian & \multicolumn{2}{|c|}{ Undifferentiated } & $\begin{array}{l}\text { Precambrian } \\
\text { confining unit } \\
\text { (assumed base of } \\
\text { ground-water-flow } \\
\text { system) }\end{array}$ & Crystalline rock \\
\hline
\end{tabular}

Figure 5. Hydrostratigraphy of northeastern Wisconsin. 


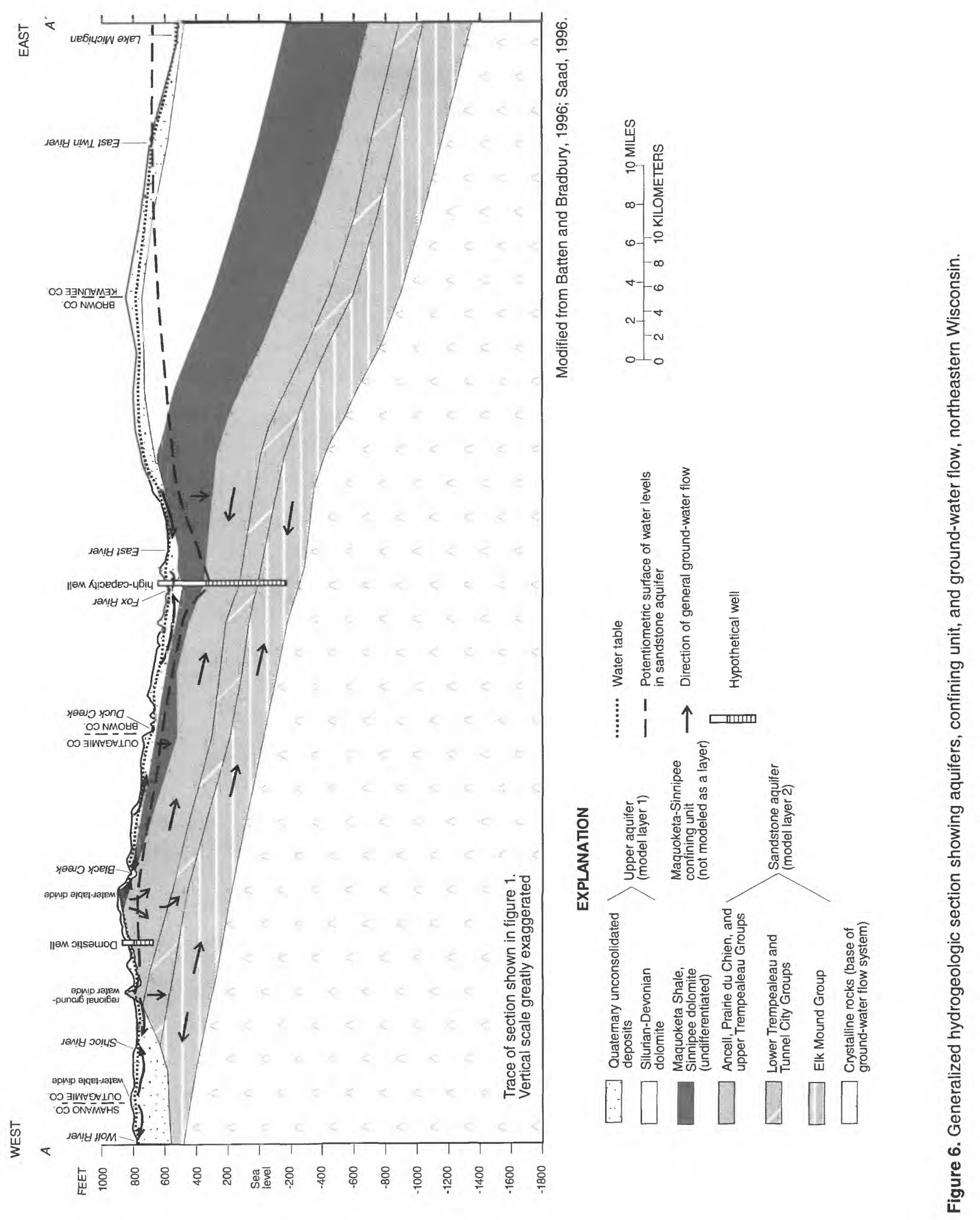


Group was considered as one aquifer (Olcott, 1966, p. 8 and 11).

Simulating ground-water flow in the aquifer system requires dividing the sedimentary rock into aquifers and confining units. In a study where ground-water flow was simulated in Brown County, Krohelski (1986, p. 11) included the upper part of the Sinnipee Group in an aquifer consisting of the unconsolidated deposits where the Maquoketa Shale is not present. Emmons (1987, p. 4) treated the entire Sinnipee Group in the current study area as part of a confining unit that included the Maquoketa Shale. Both Emmons and Krohelski divided the rock beneath the Sinnipee Group into two aquifers: an upper sandstone aquifer consisting of the St. Peter Sandstone, Prairie du Chien Group, and the upper part of the Trempealeau Group; and a lower sandstone aquifer consisting of the Elk Mound Group. These two aquifers were separated by a confining unit consisting of the lower part of the Trempealeau and all of the Tunnel City Group. The Maquoketa Shale, Sinnipee Group, and Glenwood Formation were treated as a confining unit in a multi-state study (Mandle and Kontis, 1992, p. 7). Mandle and Kontis (1992) divided the rock beneath the Glenwood Formation into three aquifers: an upper sandstone aquifer after Krohelski (1986), an aquifer consisting of the upper Elk Mound Group, and an aquifer consisting of the lower Elk Mound Group. The division of the Elk Mound Group into two aquifers was based on stratigraphy outside of northeastern Wisconsin.

For this study, the sedimentary rock beneath the Sinnipee Group is considered as one aquifer, the sandstone aquifer (fig. 5). The Maquoketa Shale and Sinnipee'Group are considered as a confining unit, the Maquoketa-Sinnipee confining unit. The Glenwood Formation is not differentiated from the St. Peter Sandstone in this study because it is thin where identified, and difficult to distinguish from the St. Peter Sandstone in well cuttings (Young, 1992b, p. 27). Above the confining unit, the unconsolidated deposits, and Silurian dolomite are treated as one aquifer, the "upper aquifer." The Devonian dolomite, which may be less permeable than the Silurian dolomite and is limited to the southeastern corner of the study area, is included in the upper aquifer. A description of, and rationale for, grouping the rocks in these aquifers and confining unit follows.

\section{Upper Aquifer}

The upper aquifer consists of the unconsolidated deposits, and the Silurian dolomite. It is present throughout the study area. For the purposes of this study, the unconsolidated deposits are considered part of the upper aquifer, although over distances of less than a mile fine-grained material may act as a confining unit. The upper aquifer is assumed to be under watertable conditions throughout the study area.

The thickness of the aquifer ranges from less than $10 \mathrm{ft}$ along the Silurian escarpment to more than $700 \mathrm{ft}$ in the eastern part of the study area (fig. 7A). The upper aquifer consists of unconsolidated deposits west of the Silurian escarpment, and unconsolidated deposits and dolomite east of the Silurian escarpment (fig. 6). The dolomite thickens, and therefore represents a greater percentage of the aquifer, in the eastern part of the study area. In the central part of the study area, the upper aquifer consists of unconsolidated deposits and is less than $100 \mathrm{ft}$ thick.

Hydraulic conductivities of the upper aquifer may vary over the study area because the texture of the glacial deposits differs over the area (table 2). Data collected from single-well tests indicate that horizontal hydraulic conductivity ranges from 0.0003 to 11.2 feet per day (ft/d); values used in previously developed calibrated ground-water-flow models range from 0.4 to $8.0 \mathrm{ft} / \mathrm{d}$. The storage coefficient, calculated from aquifer tests of wells completed in the Silurian dolomite, is 0.003 (Young, 1992b, p. B44). The storage coefficient may be higher for the upper aquifer because it includes both unconsolidated deposits and dolomite. Estimated storage coefficients used in previous ground-waterflow models range from 0.01 to 0.05 . No estimates are available for the vertical hydraulic conductivity of the upper aquifer.

\section{Maquoketa-Sinnipee Confining Unit}

The Sinnipee Group has been considered both as a confining unit and as an aquifer; however, information compiled and collected during this study indicates that the Sinnipee Group acts as a confining unit. Evidence to support this includes recorded water levels, the hydraulic properties of the Sinnipee Group characterized by single-well pumping tests in four wells, and age-dating water with tritium.

In two of four wells where testing was possible, results indicate that the Sinnipee Group acts as a con- 
A. Upper aquifer

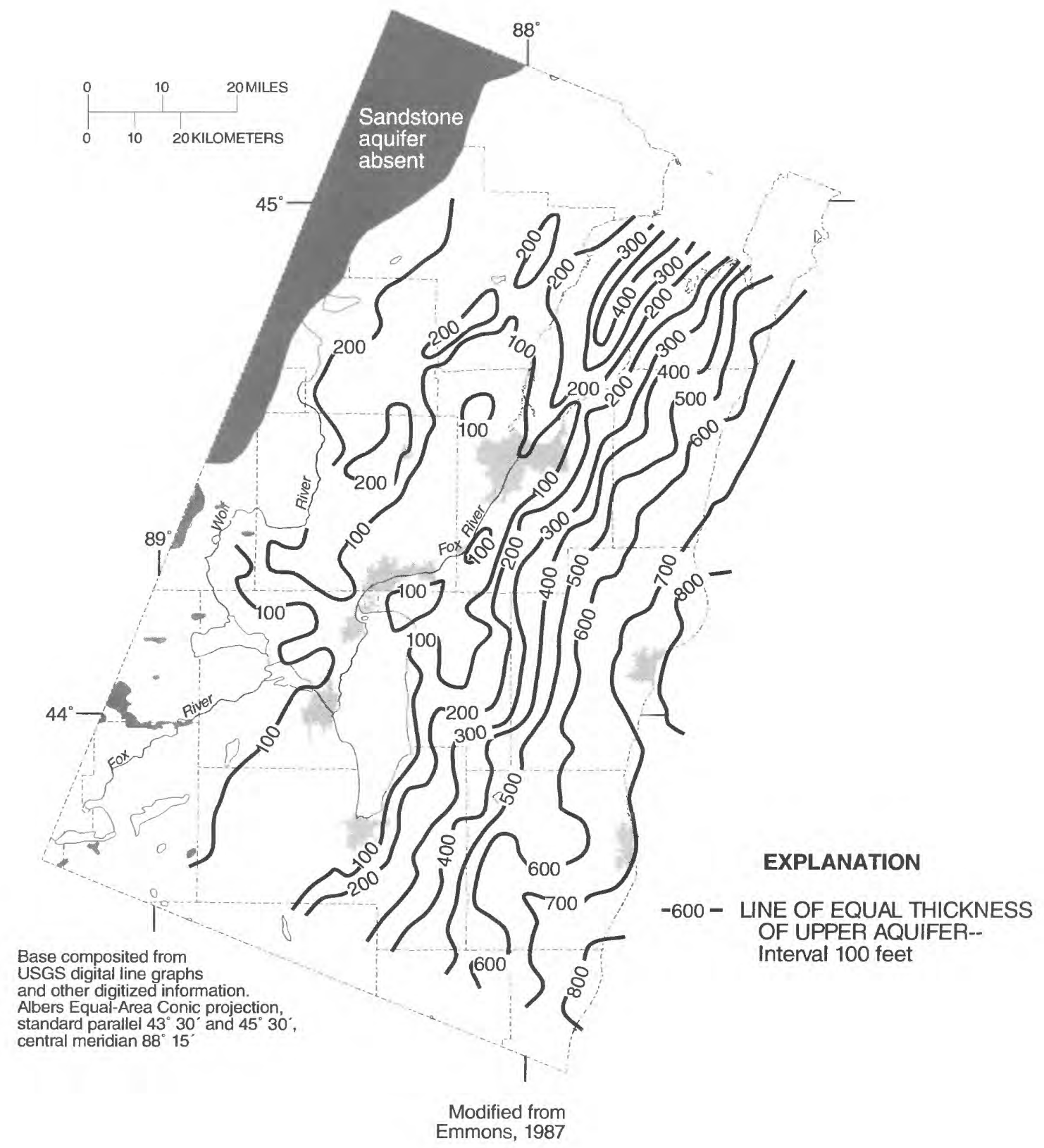

Figure 7A. Thickness of upper aquifer, northeastern Wisconsin. 
B. Maquoketa-Sinnipee confining unit

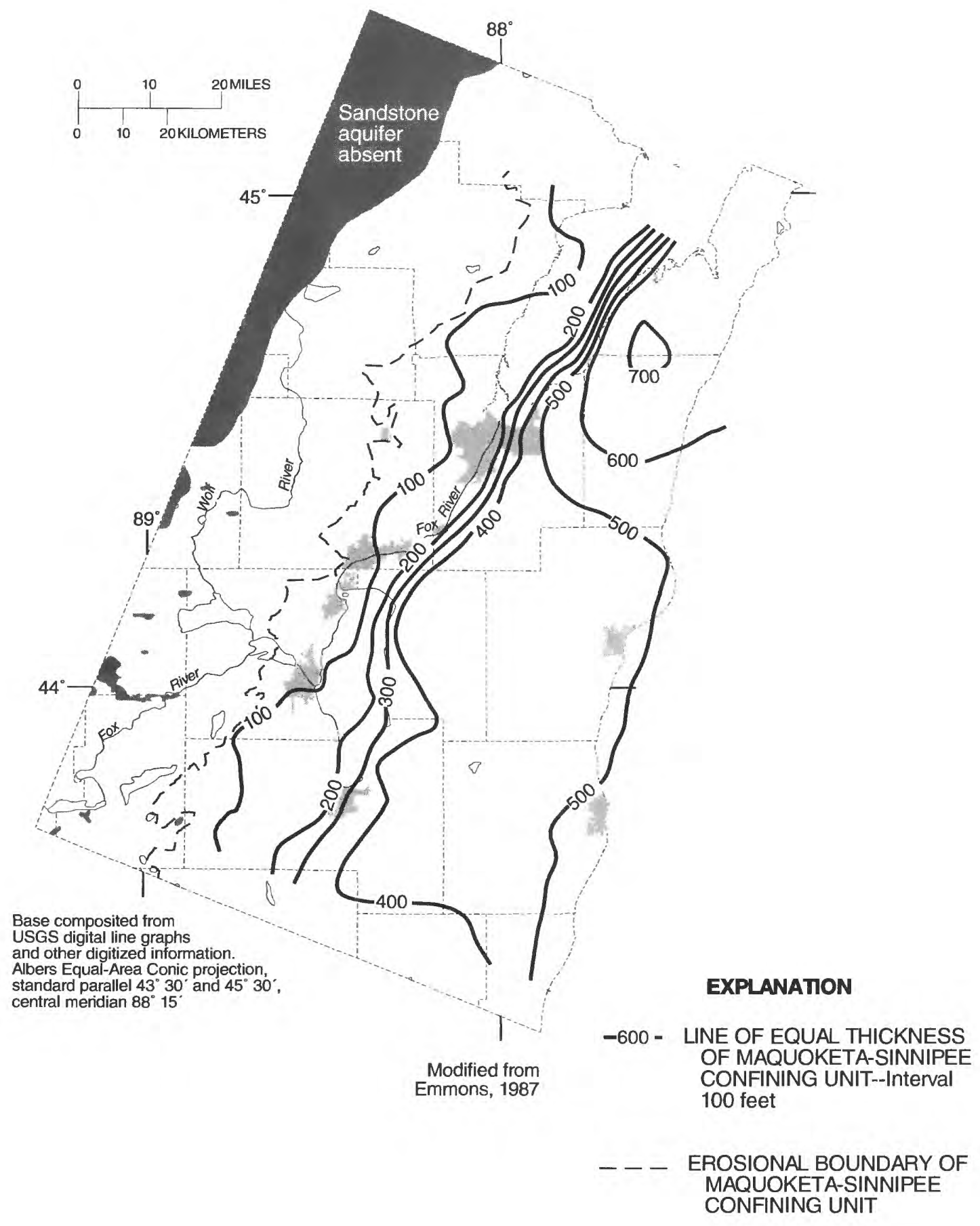

Figure 7B. Thickness of Maquoketa-Sinnipee confining unit, northeastern Wisconsin. 
C. Sandstone aquifer

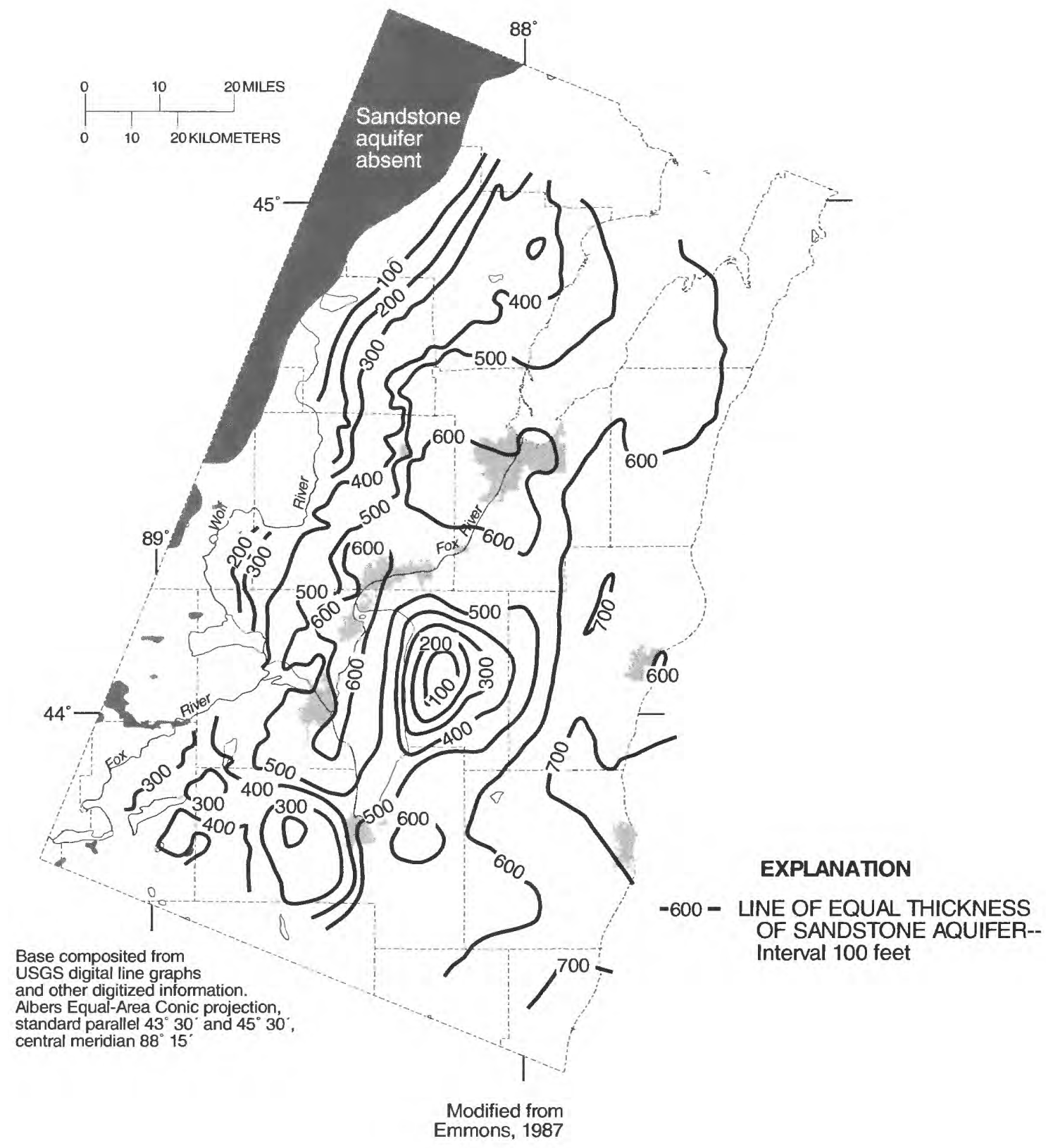

Figure 7C. Thickness of sandstone aquifer, northeastern Wisconsin. 
D. Precambrian rock surface

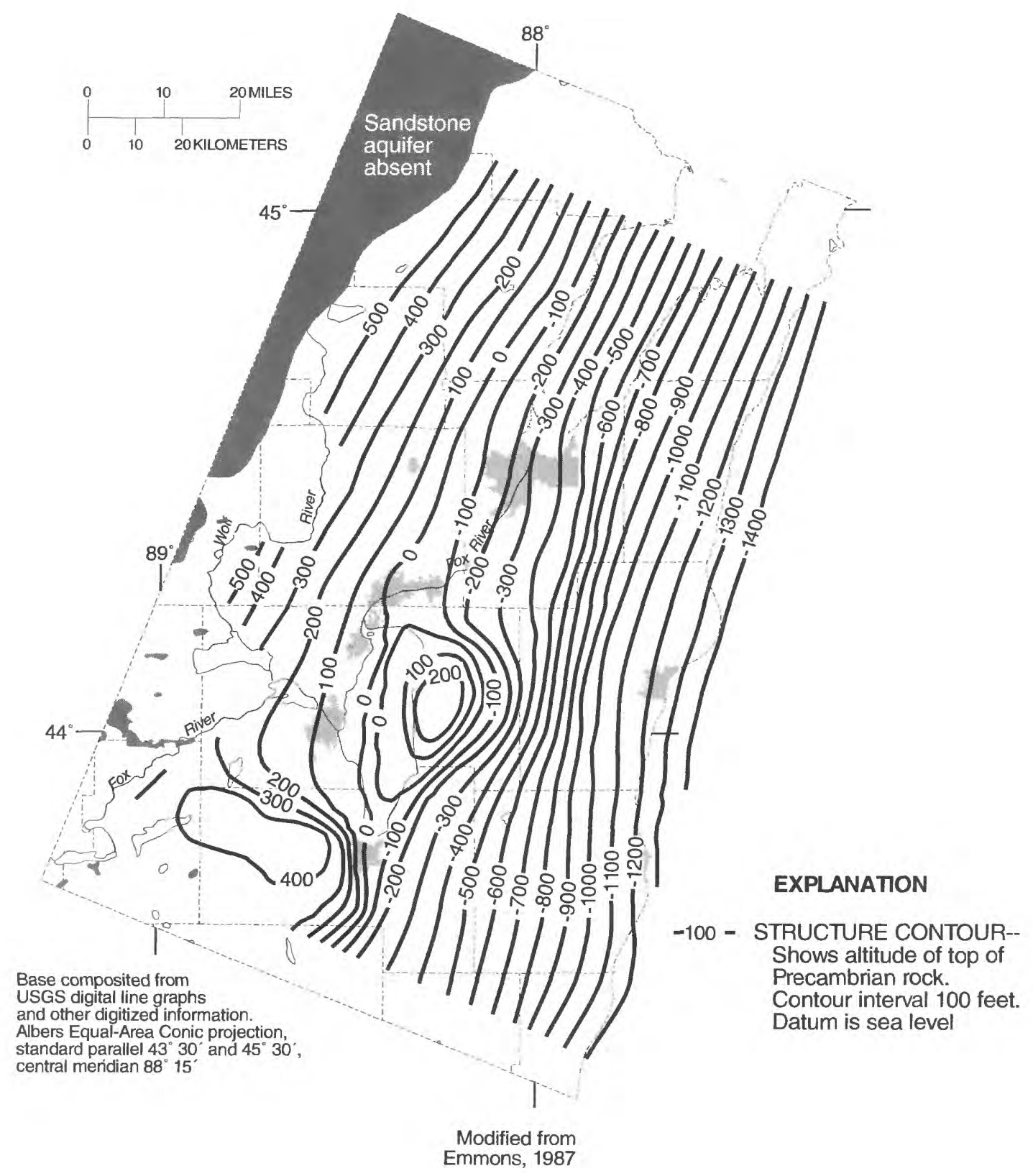

Figure 7D. Altitude of top of Precambrian rock surface beneath sandstone aquifer, northeastern Wisconsin. 


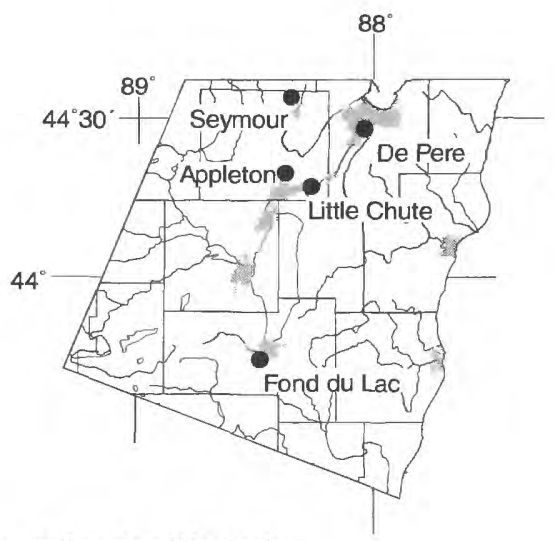

EXPLANATION

- Test well

$0 \quad 1020$ MILES

1020 KILOMETERS

A. Location of test wells, northeastern Wisconsin.

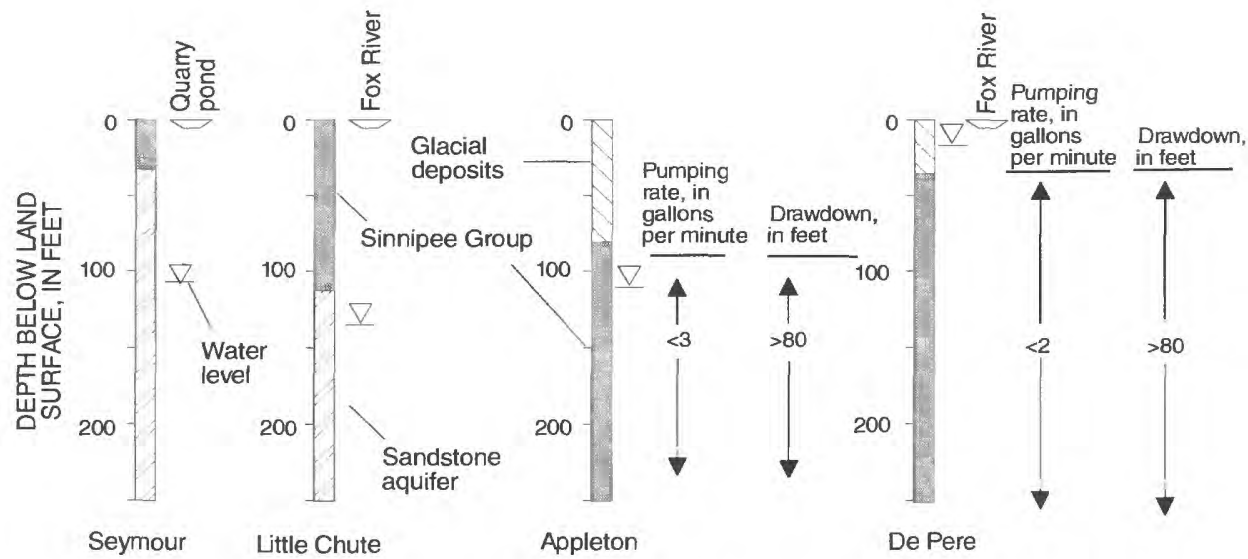

B. Test wells in northeastern Wisconsin showing yield of the Sinnipee Group and water levels in wells relative to levels in nearby surface-water bodies.
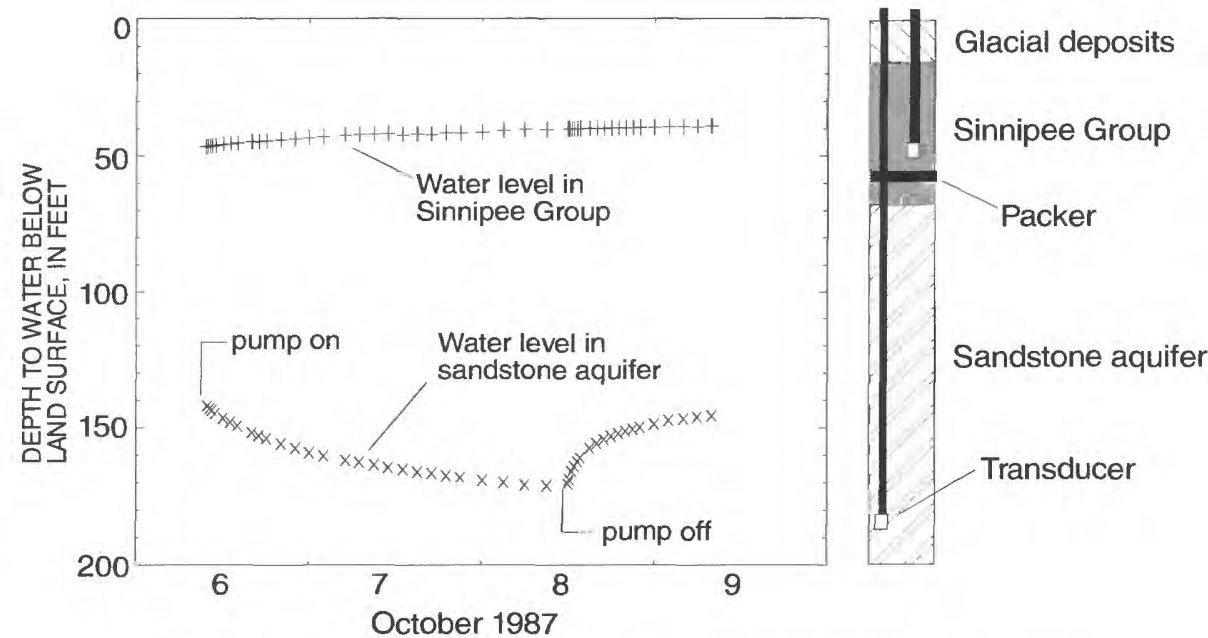

Figure 8. Evidence of the confining properties of the Sinnipee Group, northeastern Wisconsin. 
Table 2. Hydraulic properties of aquifers and confining unit, northeastern Wisconsin

[Kh, horizontal hydraulic conductivity in feet per day; S, storage coefficient, dimensionless; Kv, vertical hydraulic conductivity in feet per day; U, upper sandstone aquifer (St. Peter Sandstone, Prairie du Chien Group, Jordan Sandstone); L, lower sandstone aquifer (Elk Mound Group)]

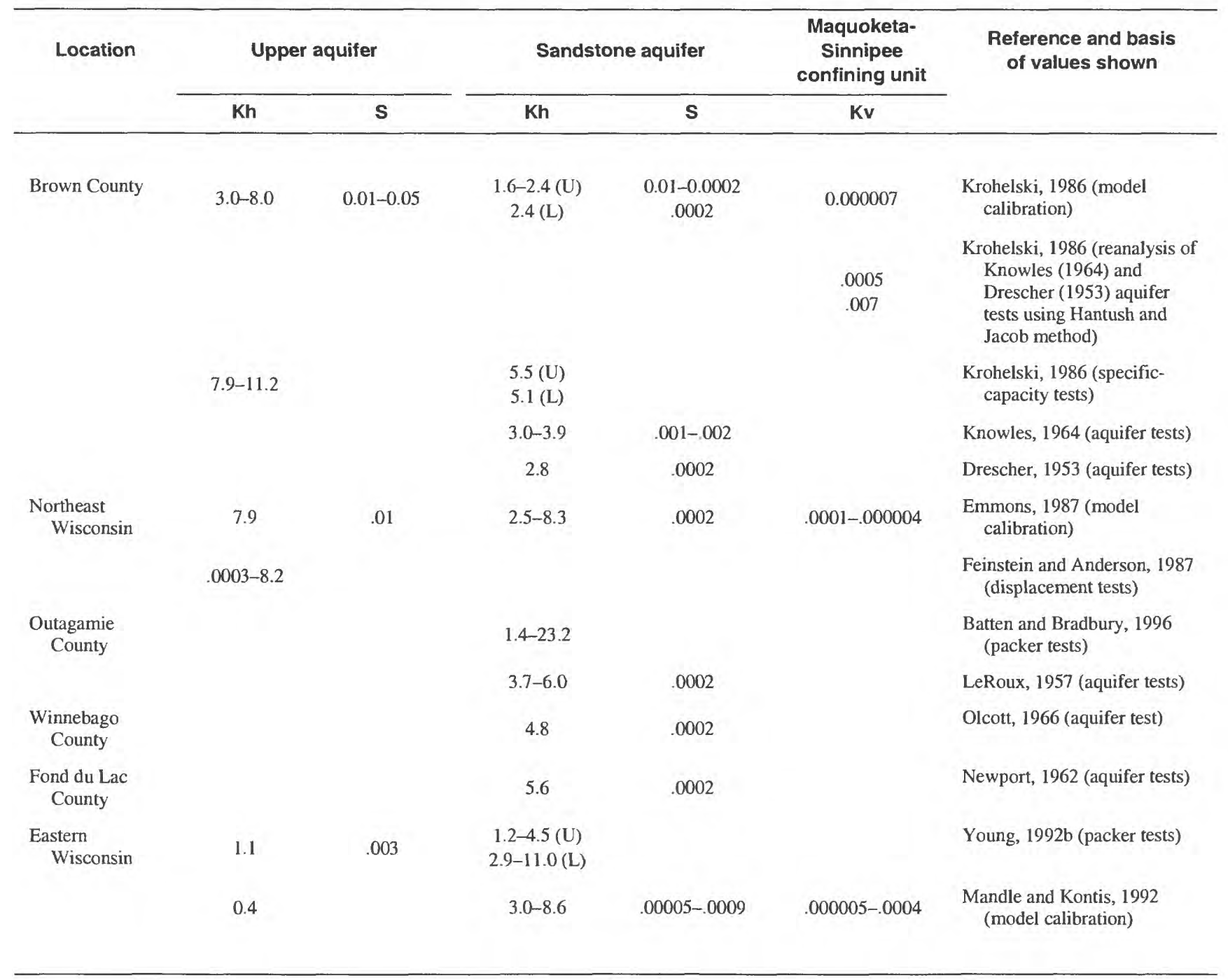

fining unit because it yields little water (less than $3 \mathrm{gal} / \mathrm{min}$ ) and pumping of the wells results in large water-level declines (either the interval was pumped dry or the water-level declined by more than $80 \mathrm{ft}$ ) (fig. 8).

Three of the four tested wells were located next to surface water bodies (fig. 8b). In two of these wells, the water level in the open borehole was below the base of the Sinnipee Group, which indicates that the Sinnipee Group acts as a confining unit by isolating surface water from ground water in the underlying sandstone aquifer and restricting water movement from the surface to the aquifer. In the test well adjacent to the Fox River near De Pere, Wis., the water level in the well is above the Sinnipee Group when a packer is inflated at the base of the Sinnipee Group. This indicates that the Sinnipee Group acts as a confining unit because the water level in the underlying sandstone aquifer is more than $300 \mathrm{ft}$ lower than the water level in the upper aquifer. When the packer was inflated at the top of the Sinnipee Group, the water in the borehole below the packer drains to the underlying sandstone aquifer. Caliper logs for wells that are cased to the top of the Sinnipee Group in the study area indicate fractur- - 
ing in the top $10 \mathrm{ft}$ of the Sinnipee Group which allows water from the upper aquifer to fill wells open to the Sinnipee Group. Consequently, many wells reported to obtain water from the Sinnipee Group may, in fact, obtain water from the overlying upper aquifer.

During an aquifer test conducted by the USGS in 1987 near Fond du Lac, Wis., water levels were monitored in a well located $20 \mathrm{ft}$ from a production well being pumped at a rate of 1,200 gallons per minute (gal/ min) (James Krohelski, U.S. Geological Survey, written commun., 1987). The water levels in the sandstone aquifer and Sinnipee Group were recorded before, during, and after pumping from the production well. The hydrograph of water levels in the Sinnipee Group (fig. $8 c$ ) indicates that the Sinnipee Group is hydraulically isolated from the sandstone aquifers and acts as a confining unit, because water levels in the Sinnipee Group were unaffected by pumping from the sandstone aquifer.

The age of water from the Sinnipee Group or the underlying St. Peter Sandstone indicates that the Sinnipee Group acts as a confining unit by restricting the flow of recent precipitation or surface water into the underlying sandstone aquifer. Water in the four wells (fig. 8) in Outagamie and Brown Counties open to the Sinnipee Group or the underlying St. Peter Sandstone is more than 30 years old based on ground-water age dating using the radioactive isotope tritium (Bradbury, 1991).

The confining unit is absent in the western part of the study area and is more than $700 \mathrm{ft}$ thick in the eastern part of the study area (fig. 7B). The confining unit thins abruptly along the Silurian escarpment where the Maquoketa Shale is truncated because of erosion and glaciation. The confining unit consists of the Sinnipee Group in the central part of the study area and the Maquoketa Shale and Sinnipee Group in the eastern part of the study area (figs. 4 and 6). The extent of the Sinnipee Group for modeling purposes (pl. 1) differs from the geologic map of the area (fig. 4) northwest of Lake Winnebago because an analysis of geologic logs in the area (G.L. Smith, Lawrence University, Appleton, Wis., written commun., 1994) indicates that the Sinnipee Group is thin and fractured where present and probably lacks the confining properties of the Sinnipee Group found elsewhere in the study area. Consequently, the confining unit is assumed to be absent in this area. The confining unit thickens to the east.

On the basis of the information presented above and findings from previous studies indicating the low yield and permeability of the Sinnipee Groups, its entire thickness is considered to be part of the Maquoketa-Sinnipee confining unit in this study. The vertical hydraulic conductivity of the Maquoketa-Sinnipee confining unit has been estimated to range from 0.0005 to 0.007 based on well tests and to range from 0.000004 to $0.0004 \mathrm{ft} / \mathrm{d}$ based on model calibration in previous studies (table 2).

\section{Sandstone Aquifer}

The sandstone aquifer consists of sedimentary rock underlying the Sinnipee Group and overlying the Precambrian crystalline rock (figs. 5 and 6). Although previous modeling studies divided the sedimentary rock into several aquifers separated by confining units, these rocks were considered as one aquifer in this study for the following reasons:

- The confining unit separating the Elk Mound Group into two aquifers is not easily distinguished (Mandle and Kontis, 1992, p. 6; Krohelski, 1986, p. 4) and may be absent (Young, 1992b, p. 16) in northeastern Wiscon$\sin$.

- The confining unit separating the upper sandstone and lower sandstone aquifers in Krohelski (1986) and Emmons (1987) may not act as a confining unit outside of the Green Bay area (Batten and Bradbury, 1996, p. 18)

- Many wells penetrate and are open to the entire sequence of sedimentary rock, which may equalize the water levels between the two sandstone aquifers of Krohelski (1986) and Emmons (1987) by allowing interaquifer flow (Young, 1992b, p. 59).

- Simulated water levels in the sandstone aquifer indicate that the potentiometric surface in the upper and lower aquifers are similar (Emmons, 1987, p. 37-38).

The sandstone aquifer is present throughout the study area except in the northwestern part, where unconsolidated deposits directly overlie the Precambrian crystalline rock. The aquifer thickens to the east, where it reaches a thickness of more than $700 \mathrm{ft}$ (fig. 7C). The sandstone aquifer thins near Precambrian highs east of Lake Winnebago and west of the city of Fond du Lac. The sandstone is confined by the Maquoketa-Sinnipee confining unit in the eastern part of the study area (figs. 4 and 6), although where water 
levels have declined to a level below the base of the Maquoketa-Sinnipee confining unit because of pumping, the aquifer is locally unconfined.

The horizontal hydraulic conductivity for the sandstone aquifer ranges from 1.2 to $23.0 \mathrm{ft} / \mathrm{d}$ on the basis of well tests and 1.6 to $8.6 \mathrm{ft} / \mathrm{d}$ on the basis of model calibration in previous studies (table 2 ). Storage coefficients, ranging from 0.0002 to 0.002 , were determined from well tests in the lower Fox River Valley, where the aquifer is confined. Estimates of storage coefficients used in ground-water-flow models ranged from 0.00005 to 0.01 . The high value, 0.01 , represents the unconfined storage coefficient and was used where the water level in the sandstone aquifer falls below the bottom of the overlying confining unit.

\section{Precambrian Base of Ground-Water-Flow System}

The Precambrian crystalline rock, which is assumed to be of low permeability, forms an impermeable base of the ground-water system. The base of the ground-water-flow system dips to the east and ranges in altitude from approximately $600 \mathrm{ft}$ in the northwest part of the study area, where it directly underlies the upper aquifer, to approximately $-1,400 \mathrm{ft}$ in the eastern part of the study area (fig. 7D). As previously mentioned, two topographic highs below the south-central part of the study area (Newport, 1962, p. 12) correspond to where the sandstone aquifer is thin.

\section{Ground-Water Movement}

Ground water moves from recharge areas to discharge areas as part of local, intermediate, and regional ground-water-flow-systems. In the local flow system, ground water travels along a short, shallow path from local topographic highs to nearby streams in topographically low areas, such as within the upper aquifer from the water-table divide to Black Creek (fig. 6). Ground water travels along long, deep paths in a regional flow system, such as from the regional ground-water divide downward through the upper aquifer and within the sandstone aquifer to deep, highcapacity wells in the lower part of the sandstone aquifer (fig. 6). Intermediate flow systems consist of flowpaths that are intermediate in length and depth.

In the upper aquifer, precipitation recharges the aquifer in topographically high areas. Ground water from the upper aquifer discharges to lakes and streams in topographically low areas. In addition, ground water discharges from the aquifer to domestic wells.

Ground water in the sandstone aquifer moves from ground-water divides to areas where upward hydraulic gradients induce discharge to the upper aquifer and to areas where wells pump water from the aquifer. The sandstone aquifer is recharged where the hydraulic gradient between the upper and sandstone aquifers is downward and the hydraulic connection between the aquifers is good, such as in the western part of the study area where the aquifer is not overlain by the Maquoketa-Sinnipee confining unit (fig. 6). Although the hydraulic gradients are downward in the lower Fox River Valley, downward flow from the upper aquifer to the sandstone aquifer is limited by the confining unit. Prior to development of the aquifer, ground-water flowed from a ground-water divide in the sandstone aquifer west to the Wolf and upper Fox Rivers and east to Lake Michigan. Since development of the aquifer, the direction of ground-water flow is similar to the predevelopment direction, except that as ground water flows east it is intercepted by wells in the lower Fox River Valley (fig. 6) and at Fond du Lac, Wis. The divide that separates the direction of flow is between the Wolf and lower Fox Rivers in the northern part of the study area and between the upper Fox River and the city of Fond du Lac in the southern part of the study area.

West of the western extent of the MaquoketaSinnipee confining unit, the sandstone aquifer is unconfined and in good hydraulic connection with the unconsolidated deposits of the upper aquifer. Where hydraulic gradients are downward, flow from the upper aquifer is downward to the sandstone aquifer; where gradients are upward, flow from the sandstone aquifer is upward to the upper aquifer.

In the eastern two-thirds of the study area, the Maquoketa-Sinnipee confining unit restricts vertical flow between the upper and sandstone aquifers. Upward and downward flow occurs according to the hydraulic gradient between aquifers, however, the amount of flow is less than under similar circumstances in the western part of the study area because of the presence of the confining unit.

\section{Recharge}

Recharge to the upper aquifer is from infiltration of precipitation, seepage from lakes and streams, and upward flow from the sandstone aquifer where upward 
hydraulic gradients occur. Recharge to the upper aquifer has been estimated to be approximately 10 percent of annual precipitation, 3 inches per year (in/yr), in Fond du Lac county (Newport, 1962, p. 22), between 1 and $8 \mathrm{in} / \mathrm{yr}$, as indicated by water-table fluctuations and stream base flow (Krohelski, 1986, p. 14-16), and 0.4 in/yr by model calibration (Krohelski, 1986, p. 34). The low recharge estimated in the calibrated model may be reasonable because of the presence of fine-grained lake clay and clayey tills in northeastern Wisconsin, which limits infiltration of precipitation into the upper aquifer. Another possible reason for the low recharge is that Krohelski's model (1986) was discretized relatively coarsely and could not simulate short flowpaths or heterogeneity in the upper aquifer. In a finite-difference ground-water-flow model with finer discretization, estimated average recharge rate was $1.4 \mathrm{ft} / \mathrm{yr}$ (Feinstein, 1987, p. 98).

Recharge to the sandstone aquifer is from downward flow from the upper aquifer to the sandstone aquifer where hydraulic gradients are downward. The Maquoketa-Sinnipee confining unit limits recharge to the sandstone aquifer in the eastern two-thirds of the study area.

\section{Stream-Aquifer Interaction}

Flow may occur between surface-water bodies and the upper aquifer if there is a gradient between the stream and aquifer, and if they are hydraulically connected. The aquifer is either recharged or contributes water to the stream depending on the direction of the gradient. The hydraulic connection between an aquifer and stream, or any other surface-water body, can be expressed as leakance which equals the vertical hydraulic conductivity of the streambed material divided by the thickness of the material. Stream leakance calculated using Darcy's Law in Dane County, Wis., ranged from 1.6 to 37 day $^{-1}\left(\mathrm{~d}^{-1}\right)$, with a mean value of $8.1 \mathrm{~d}^{-1}$ (Krohelski and Bradbury, in press). Lakebed leakance is expected to be lower than streambed leakance because the bed material in lakes is finer grained (has a lower vertical hydraulic conductivity) and may be thicker than that in streams.

Streambed and lakebed leakances in the study area are expected to be lower than leakances in Dane County, because the unconsolidated deposits in northeastern Wisconsin, and therefore streambed material, is expected to have a lower hydraulic conductivity than that in Dane County.

\section{Ground-Water Use and Water Levels}

Ground-water is withdrawn for domestic, agricultural, commercial and industrial uses in the study area. Most communities east of the Silurian escarpment withdraw water from the upper aquifer, except for the cities on the shore of Lake Michigan, which use surface water. Pumping from the sandstone aquifer in the industrialized communities along the lower Fox River Valley and the city of Fond du Lac account for the majority of ground-water withdrawals in the study area. For the purposes of this study, only withdrawals from municipal and high-capacity (greater than 100,000 gallons per day (gal/d) industrial or commercial water wells open to the sandstone aquifer in Brown, Outagamie, Winnebago, and Fond du Lac counties were compiled, because these wells pump at high rates and account for most withdrawals from the sandstone aquifer. Withdrawals from the upper aquifer were not included because pumping rates from wells completed in the upper aquifer are lower than those from wells completed in the sandstone aquifer.

Wells tapping the sandstone aquifer were first drilled in the late 1800's. Chamberlain (1878) reported several wells in the study area, and the selected rates of withdrawal from the sandstone aquifer were documented by Weidman and Schultz (1915). Using ground-water withdrawal data available from previous ground-water modeling studies (Krohelski, 1986; Emmons, 1987; Young, 1992b; and Mandle and Kontis, 1992) and recent pumping records, groundwater use information for the study area for 1880 to 1990 was compiled (appendix A). An average withdrawal rate for each well pumping from the sandstone aquifer is assumed to be constant over a period of time, or stress period.

Total withdrawals from the sandstone aquifer increase over time (fig. 9), except in 1957, when the city of Green Bay ceased pumping from the sandstone aquifer and began using water from Lake Michigan. Ground-water withdrawals from the sandstone aquifer have declined slightly for Winnebago County since 1970 because industrial users have pumped less water. Withdrawals for municipal use account for most of the pumping from the sandstone aquifer (fig. 9B). The total 1990 withdrawal rate exceeds the total withdrawal rate 
A.

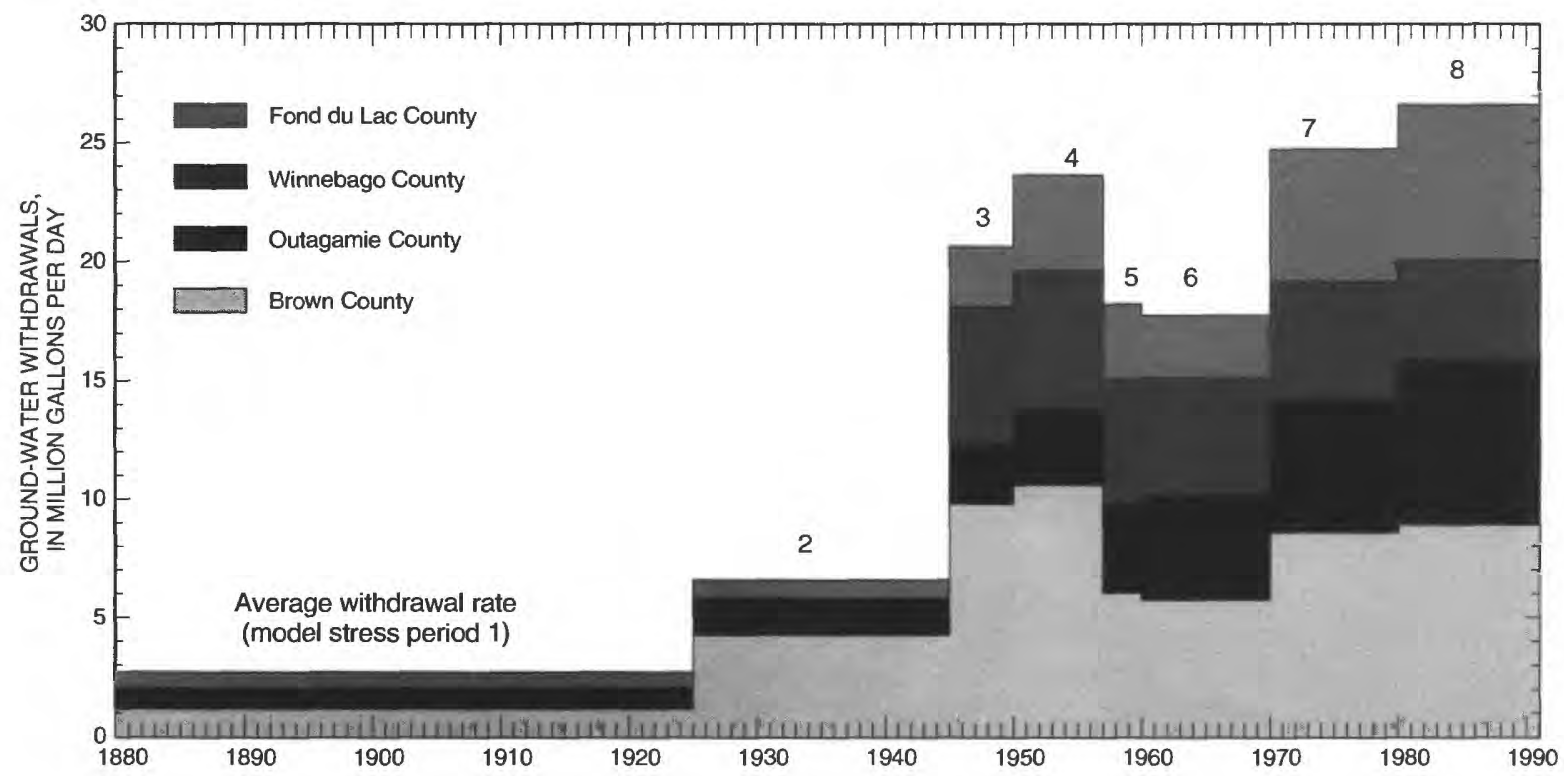

B.

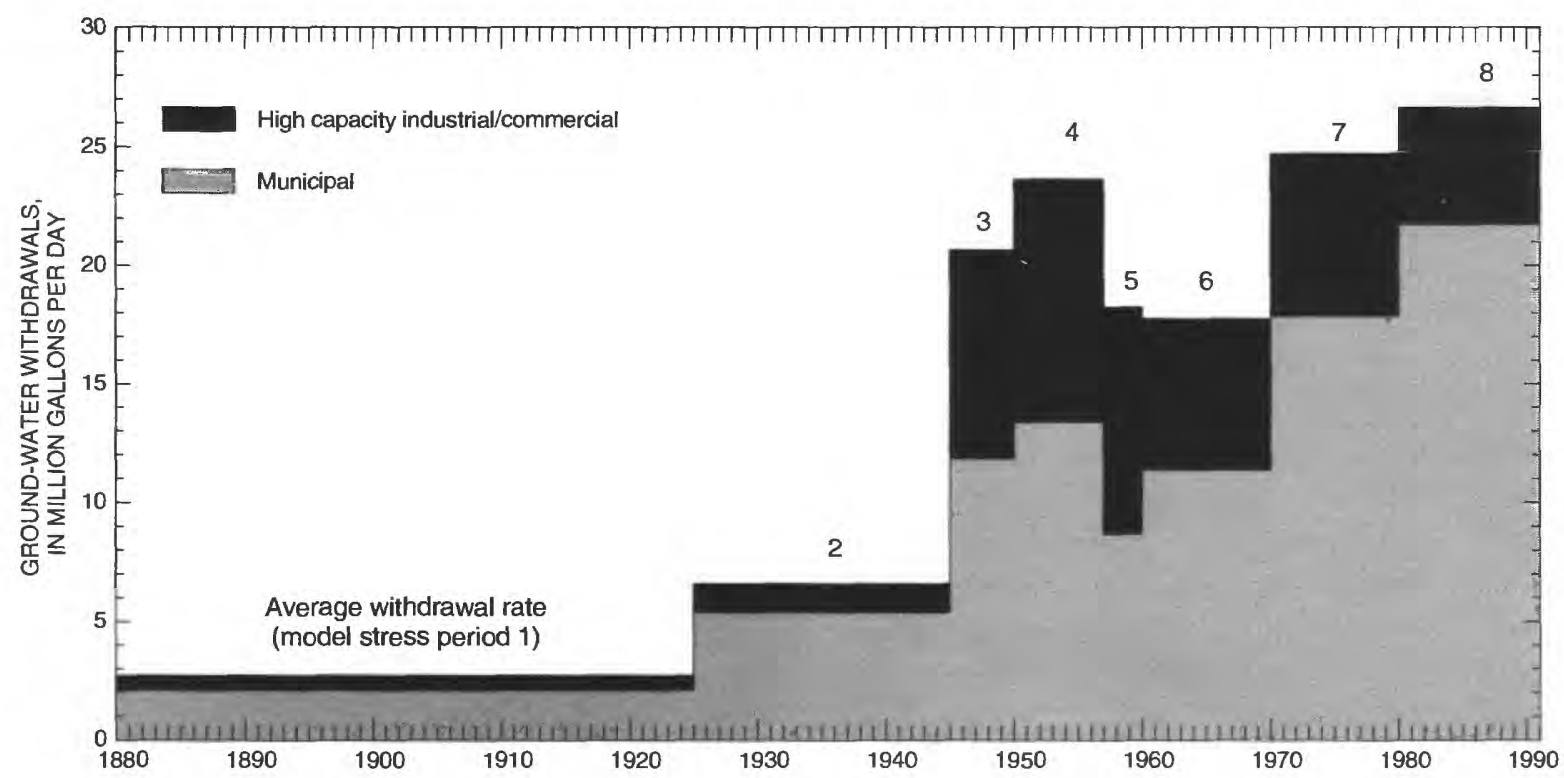

Figure 9. Ground-water withdrawals from the sandstone aquifer, by (A) county and (B) type of use, northeastern Wisconsin. 


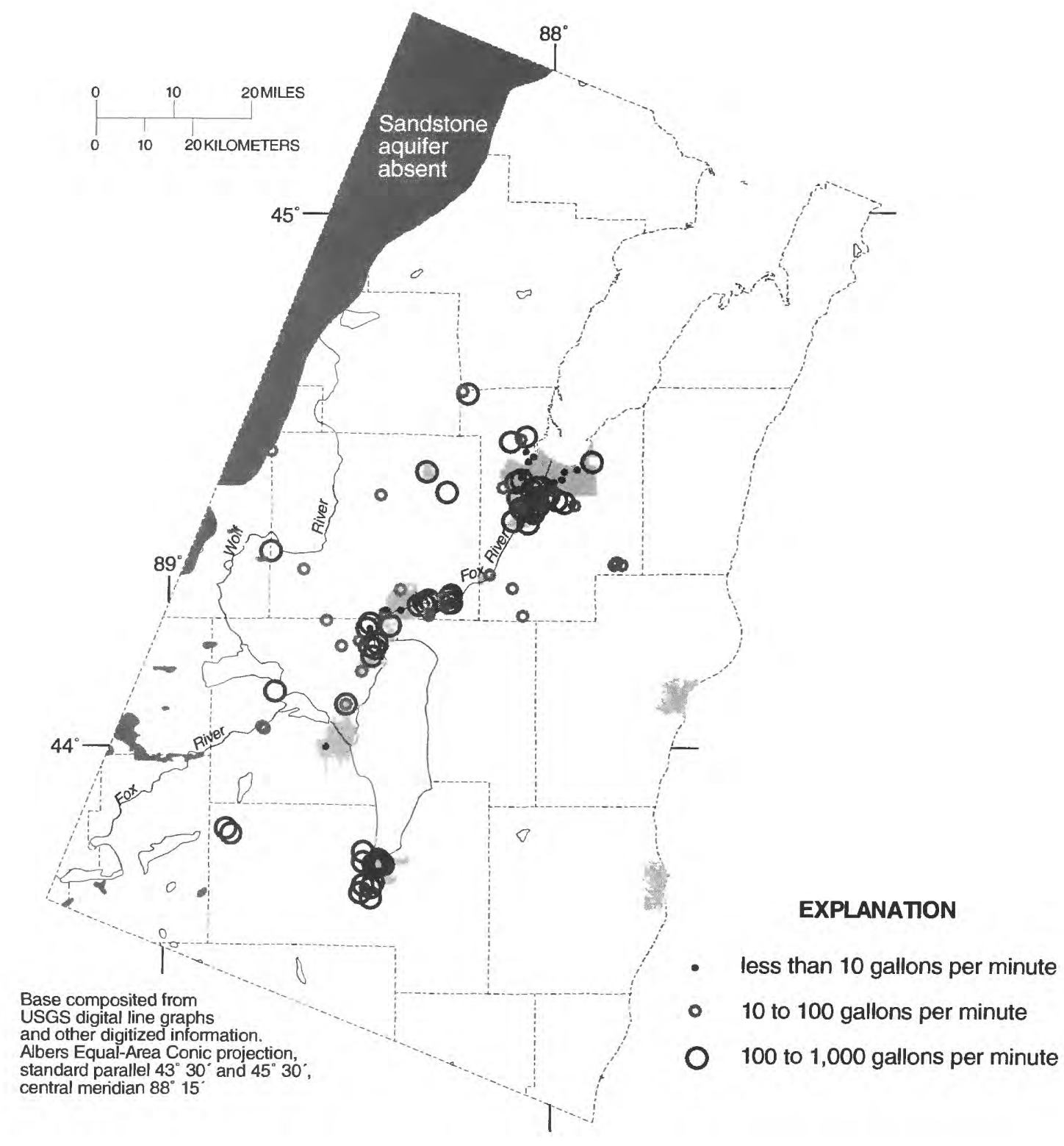

Figure 10. Map showing locations of high-capacity municipal and industrial wells and magnitude of withdrawals from the sandstone aquifer, northeastern Wisconsin, 1990. 
of 1957 when Green Bay was withdrawing ground water. Most of this increase is caused by pumping from suburban Green Bay municipalities, the Fox Cities in Outagamie Winnebago Counties, and Fond du Lac County (figs. 9 and 10).

Water levels fluctuate because of changes in ground-water withdrawals, precipitation, evapotranspiration, and barometric pressure. Although water levels in the upper aquifer fluctuate because of these influences, withdrawals from wells completed in the sandstone aquifer tend to have the greatest effect on water levels. Hydrographs of water levels in the sandstone aquifer near Green Bay (see fig. 15) show declines prior to 1957 and a recovery in 1957 because the city of Green Bay ceased pumping from the aquifer. Since approximately 1960, water levels have declined because of increasing water withdrawals by suburban Green Bay communities. The current rate of waterlevel decline in the sandstone aquifer in the Green Bay area is approximately $4 \mathrm{ft} / \mathrm{yr}$. The rate of decline in the Fox Cities area, approximately $2 \mathrm{ft} / \mathrm{yr}$, is less than the decline in the Green Bay area because of lower withdrawal rates. The rate of decline in the sandstone aquifer in Winnebago County is minimal because withdrawal rates are small.

\section{SIMULATION OF GROUND-WATER FLOW}

Where hydrogeology is complex and interference between pumping wells is common, estimating aquifer water levels and delineating contributing areas to wells by use of analytical techniques may not be practical. Consequently, in this study a ground-waterflow model was used to simulate ground-water flow and water levels in the sandstone aquifer and upper aquifer in northeastern Wisconsin. A transient groundwater-flow model using the computer program MODFLOW (McDonald and Harbaugh, 1988) was developed to improve the understanding of the hydrogeology before pumping commenced and the changes caused by pumping from the sandstone aquifer. This model can also be used to simulate possible future ground-water withdrawal alternatives and delineate flowpaths and contributing areas of wells.

In the model, the partial differential groundwater-flow equation is solved numerically with a computer. The study area is discretized into a number of cells or blocks. A point, or node, is at the center of each cell. The array of cells and nodes is called a grid and locations within the model are designated by row and column number. In the finite-difference method, the ground-water-flow equation is approximated for each cell in the grid. The system of equations is then solved iteratively until an acceptable agreement between two successive iterations is reached. The user specifies the acceptable amount of difference between two iterations. In a transient simulation, time is discretized into stress periods, periods of time in which stresses, such as pumping, are constant; and time steps, increments of time within a given stress period. The simulated water levels in the aquifers and simulated flows in streams are compared to measured water levels and flows to assess the accuracy of the model. When simulated values reasonably match measured values, the model is considered calibrated. Following calibration, the model can be used to simulate water-level fluctuations that would result from projected pumping.

\section{Description of Numerical Model}

The model area (fig. 1) was discretized by use of a finite-difference grid (pl. 1). The extent of the model area was chosen so that (1) the western boundary includes the western ground-water divide in the sandstone aquifer and the discharge areas of the Wolf River in the north and the upper Fox River in the south, (2) the northern boundary was set to a sufficient distance where the effects of pumping in the lower Fox River Valley on water levels would be minimal, (3) the southern boundary includes the area of water withdrawals near the city of Fond du Lac, and (4) the eastern boundary incorporates a ground-water discharge divide in Lake Michigan. The grid is rotated $23^{\circ}$ east of north to orient the northern and southern boundaries to the major direction of ground-water flow in the sandstone aquifer.

The model contains 141 rows and 102 columns and two layers: layer 1 simulates conditions in the upper aquifer, and layer 2 simulates conditions in the sandstone aquifer. The thickness of each layer is a discretized version of figures $7 \mathrm{~A}$ and $7 \mathrm{C}$ for the study area. Under Lake Michigan, the thickness of each layer was extrapolated to increase at a rate similar to that within the study area. Each layer contains 14,382 cells that range in size from $1,320 \mathrm{ft}$ on a side (an area of $1 / 16 \mathrm{mi}^{2}$ or 40 acres) in the lower Fox River Valley to a rectangular cell with dimensions up to $8 \mathrm{mi}$ by $32 \mathrm{mi}$ (an area of $256 \mathrm{mi}^{2}$ ) in the northeast corner of the model area. A variable-spaced grid was used to simu- 
late ground-water conditions in detail in the lower Fox River Valley, where many wells pump water from the sandstone aquifer, and to simulate in less detail those areas far from the lower Fox River Valley. Of the 14,382 cells, the upper aquifer is simulated with 11,301 active cells (including 522 head-dependent cells that underlie streams where the confining unit is not present) where water levels are calculated by the model (pl.1). The remaining cells are constant head $(2,501)$, where lakes and streams overlie the confining unit, or inactive (580) cells. The sandstone aquifer is simulated with 13,701 active cells, 101 constant-head cells to simulate a ground-water divide at the southern boundary, and 580 inactive cells.

The Maquoketa-Sinnipee confining unit is not simulated as a model layer, but as a boundary that allows vertical flow between the upper aquifer (model layer 1 ) and the sandstone aquifer (model layer 2). The ability of water to flow across this boundary, known as vertical conductance, is proportional to the vertical leakance, which is the vertical hydraulic conductivity of the confining unit divided by the thickness of the confining unit (fig. 7B).

\section{Model Assumptions and Boundary Conditions}

The model used in this study assumes that flow in the aquifers is horizontal, flow between the aquifers is vertical, hydraulic properties are uniform within each cell, and assigned and simulated water levels are at the center, or node, of each cell. Horizontal flow is assumed because the horizontal extent of the aquifer system is much greater than the thickness of the aquifers. Recharge is applied to the uppermost active model layer at a uniform rate over the modeled area and does not vary temporally. Seasonal changes in water levels as a result of changes in precipitation, evapotranspiration, or land use are not simulated in the model. Vertical flow through the Maquoketa-Sinnipee confining unit and no release of water from storage in the confining unit was assumed because there was no need to simulate heads in the unit, and the hydraulic conductivities of the upper and sandstone aquifers are much greater than the hydraulic conductivity of the confining unit. Where the confining unit is absent, the model uses a higher value of vertical conductance to simulate the hydraulic connection between the upper and sandstone aquifers.

\section{Upper Aquifer (Layer 1)}

The upper aquifer is simulated as a water-table aquifer. Hydraulic conductivity and the storage coefficient for the upper aquifer are assumed to be uniform vertically and laterally over the study area, but the thickness of the aquifer varies laterally. The upper aquifer contains no-flow, constant-head, and headdependent conditions. No-flow conditions represent a boundary to an active cell across which water may not flow. No flow boundaries are assigned to the edge of the model where no surface-water bodies (lakes and streams) are present. Constant-head boundaries are assigned to cells where a surface-water body is present above a cell in the upper aquifer and the water level, or head, in the cell is held constant and equal to the water level in the surface-water body. Head-dependent conditions are assigned where a surface-water body is present above a cell in the upper aquifer. The simulated ground-water level in a head-dependent cell may fluctuate in response to stresses in the aquifer. The hydraulic connection between the water body and the aquifer cell is proportional to the leakance and the hydraulic gradient between the surface-water body and the aquifer. Streambed or lakebed leakance is the vertical hydraulic conductivity of the streambed or lakebed material divided by the thickness of the streambed or lakebed material.

Most of the western boundary of the upper aquifer is simulated as a head-dependent boundary where surface water bodies, such as the Wolf and the upper Fox Rivers, intersect the model grid (pi. 1). Seven cells along this boundary contain no rivers and are simulated as no-flow boundaries. The eastern boundary is simulated as a constant-head boundary because the upper aquifer is overlain by Lake Michigan. The northern and southern boundaries contain a combination no-flow, constant-head, and head-dependent conditions (pl. 1). No-flow conditions along the northern boundary are assigned to cells that do not contain a surface-water body. Constant-head conditions are assigned where cells are overlain by a surface-water body and underlain by the Maquoketa-Sinnipee confining unit. Headdependent boundaries are used where the MaquoketaSinnipee confining unit is not present and surfacewater bodies intersect the model grid. Internal boundaries in the upper aquifer include selected streams and lakes. These surface-water bodies are simulated as head-dependent boundaries where the Maquoketa-Sin- 
nipee confining unit is absent and as constant head boundaries where the confining unit is present.

\section{Sandstone Aquifer (Layer 2)}

The sandstone aquifer is simulated as a convertible model layer, which means that the aquifer is simulated as a confined aquifer but will change to unconfined conditions when water levels in the aquifer fall below the bottom of the overlying confining unit. All boundaries of the sandstone aquifer are no-flow boundaries except the southern boundary, where constant-head conditions are simulated. A constant-head boundary was used because the southern boundary is far from the area of interest in the lower Fox River Valley, and the location of the boundary coincides with a mapped ground-water divide that separates depressions in the potentiometric surface of the sandstone layer from pumping in the Milwaukee metropolitan area to the south and the Fond du Lac area to the north. The water levels assigned to the boundary were obtained from unpublished maps, available at the Wisconsin District office of the U.S. Geological Survey, which show the predevelopment and 1984 water levels in the sandstone aquifer. The maps indicate that the boundary has not changed location since predevelopment. Although the head at this boundary has changed over time, changes in head were not simulated at this boundary because these changes have not been quantified and do not affect the simulated water levels in the lower Fox River Valley. The bottom of the sandstone aquifer is assumed to be a no-flow boundary.

Wells are simulated as withdrawing water from the entire thickness of the sandstone aquifer. A well is assumed to withdraw water from the center of the cell, and multiple wells in a cell are simulated as one well withdrawing water at a rate equal to the sum of the rates of all wells in the cell. Ground-water withdrawal rates are constant over a stress period but may vary from stress period to stress period (fig. 9). Daily or seasonal variations in pumping from the sandstone aquifer are not simulated. The quantity of water pumped from the upper aquifer is not simulated because it is small relative to the quantity pumped from the sandstone aquifer and is assumed to have a negligible effect on water levels in the sandstone aquifer.

\section{Model Input}

MODFLOW (McDonald and Harbaugh, 1988) requires that each cell be assigned hydraulic properties. In addition, some cells may have a flux rate assigned to simulate recharge or withdrawal of water. Through trial-and-error, the combination of hydraulic properties that acceptably simulates historical water levels and flows is identified. The type of model input and the values that were used in the model to simulate historical conditions are discussed below.

The model cells for the upper aquifer were assigned to be inactive, active, head dependent, or constant head (pl. 1). Model input for head-dependent cells include the stream or lake stage, vertical conductance of the streambed or lakebed, and altitude of the base of the bed material. Vertical conductance of the streambed or lakebed was calculated for each cell containing a stream or lake simulated using head-dependent conditions by multiplying the vertical leakance of 0.5 $\mathrm{d}^{-1}$ for lakes and $1.0 \mathrm{~d}^{-1}$ for streams by the length and width of the water body in the cell. Length was calculated by the Geographic Information System (GIS) and width was assigned on the basis of relative size of the stream. Model input for constant-head cells is the water level obtained from topographic maps or digital GIS data for the stream or lake that intersects the cell.

The altitude of the bottom of the upper aquifer, and the top and bottom of the sandstone aquifer were assigned to cells from contour maps (fig. 7). The vertical conductance of the confining unit, where it is present, is calculated by multiplying the vertical leakance by the area of the cell. The vertical leakance is equal to the vertical hydraulic conductivity of the Maquoketa-Sinnipee confining unit, $0.000035 \mathrm{ft} / \mathrm{d}$, divided by the variable thickness (fig. 7B) of the confining unit. Where the confining unit is not present, a vertical leakance of $0.0015 \mathrm{~d}^{-1}$ was assigned on the basis of hydraulic properties of the upper and sandstone aquifers.

Two horizontal hydraulic conductivity values were assigned for the sandstone aquifer. In the western part of the aquifer (west of column 61 in the model, pl. 1), where the sandstone aquifer is not overlain by a large thickness of the Maquoketa-Sinnipee confining unit, and near Fond du Lac, where more permeable St. Peter Sandstone constitutes a large proportion of the sandstone aquifer (Newport, 1962, pl. 3), the horizontal hydraulic conductivity is $3.0 \mathrm{ft} / \mathrm{d}$. In the eastern part, where the sandstone aquifer is overlain by a large 
Table 3. Parameter values used in the ground-water-flow model for northeastern Wisconsin

[--, not applicable; Kh, horizontal hydraulic conductivity; NI, not model input; S, storage coefficient; Kv, vertical hydraulic conductivity]

\begin{tabular}{|c|c|c|c|c|c|}
\hline \multirow[b]{2}{*}{ Input parameter } & \multicolumn{3}{|c|}{ Aquifer or confining unit } & \multicolumn{2}{|c|}{ Surface-water bodies } \\
\hline & Upper aquifer & $\begin{array}{l}\text { Maquoketa- } \\
\text { Sinnipee } \\
\text { confining unit }\end{array}$ & $\begin{array}{l}\text { Sandstone } \\
\text { aquifer }\end{array}$ & Streams & Lakes \\
\hline Thickness (feet) & $20-1,100$ & $0-800$ & $0-1,100$ & -- & -- \\
\hline Kh (feet per day) & 3.3 & NI & $1.5,3.0^{\mathrm{a}}$ & -- & -- \\
\hline $\mathrm{S}$ (dimensionless) & .03 & NI & $.0002, .01^{\mathrm{b}}$ & - & -- \\
\hline Kv (feet per day) & NI & $.0015, .000035^{\mathrm{c}}$ & NI & -- & -- \\
\hline $\begin{array}{l}\text { Leakance }(\mathrm{Kv} / \mathrm{bed} \\
\left.\text { thickness; } \mathrm{d}^{-1}\right)\end{array}$ & -- & - & -- & 0.5 & 1.0 \\
\hline $\begin{array}{l}\text { Recharge rate (inches } \\
\text { per year) }\end{array}$ & & 0.7 & lies to all of $\mathrm{m}$ & & \\
\hline
\end{tabular}

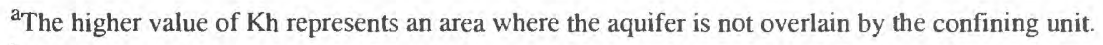

${ }^{\mathrm{b}}$ The higher value of $\mathrm{S}$ is used when water level falls below bottom of overlying confining unit.

${ }^{c}$ The higher value of $\mathrm{Kv}$ represents an area where the confining unit is absent. The lower value represents an area where the confining unit is present.
}

thickness of the confining unit, the horizontal hydraulic conductivity is $1.5 \mathrm{ft} / \mathrm{d}$.

Vertical hydraulic conductivity of the confining unit $(0.000035 \mathrm{ft} / \mathrm{d})$, horizontal hydraulic conductivity of the upper aquifer ( $3.3 \mathrm{ft} / \mathrm{d})$, storage coefficients of the upper aquifer (0.03) and sandstone aquifer $(0.0002$ for confined and 0.01 for unconfined conditions), and recharge $(0.7 \mathrm{in} / \mathrm{yr})$ were assumed to be uniform in space and time. The hydraulic properties used in the model (table 3 ) are within or are reasonably close to the range of measured values (table 2). Pumping was simulated for wells at the rates listed in appendix A.

\section{Model Calibration}

The ground-water-flow model was calibrated under steady-state conditions at predevelopment and under transient conditions in 1957 and 1990. The model was calibrated to 19 water levels representing the potentiometric surface of the sandstone aquifer around the time of predevelopment for the steady-state simulation, 21 water levels measured in 1957 prior to the city of Green Bay replacing ground water with surface water as their water supply, and 16 water levels measured in 1990 for the transient simulation. The water-level measurements used in the calibration were made in non-pumped observation wells completed in the sandstone aquifer. Streamflow at one stream, Pensaukee River (pl. 1), which was simulated as a head-dependent boundary, and at four streams-Duck Creek, and Suamico, East and Fond du Lac Rivers (pl. 1) - which were simulated as constant-head boundaries, was compared to base flow calculated on the basis of discharge measurements. Other streams, simulated as head-dependent boundaries, were not included as calibration targets because their entire drainage areas were not simulated, or discharge measurements were not available for the section of the stream that flows through the modeled area. Simulated flow in 1990 was considered to adequately match mea- 
sured base flow if the simulated flow was between a lower value of base flow equal to the discharge that is exceeded 90 percent of the period of record and an upper value equal to the discharge that is exceeded 50 percent of the period of record. Values of baseflow for the Pensaukee River, Duck Creek, and East River are from Holmstrom and others (1995), and values of base flow for the Suamico and Fond du Lac Rivers were calculated from measurements available from the USGS at stream gaging stations that have been discontinued (Holmstrom and others, 1995).

The ground-water-flow model was calibrated by a trial-and-error method, in which a series of adjustments to the hydraulic properties of the aquifer and confining units are made until a reasonable match is produced between the simulated and calculated water levels in the sandstone aquifer and between the simulated discharge to streams and the calculated base flow. Simulated water levels were compared to measured water levels by use of the root mean square (RMS) error for observation wells. In addition, simulated water levels were contoured and the contour maps of simulated water levels were compared to contour maps of measured water levels as a qualitative indication of calibration. Simulated contours (figs. 11 and 12) do not extend to the model boundaries (pl. 1) because simulated water levels are available only at the center of model cells. To evaluate whether the transient model adequately simulates the trend in water levels over time, simulated water levels at the end of each stress period were plotted on hydrographs of water levels for selected wells. Although the model area extends eastward under Lake Michigan (fig. 1), this report will limit discussion and figures to the study area, the area covered by land and Green Bay.

\section{Steady-State Simulation}

Water levels in the sandstone aquifer prior to pumping from the aquifer were simulated with steadystate conditions. Because no water-level data are available for the sandstone aquifer prior to ground-water development, which began in the 1880's, simulated water levels were compared to water levels measured in the early 1900's (Weidman and Schultz, 1915). The measurements reflect aquifer water levels soon after development began. Consequently, the measured water levels reported by Weidman and Schultz (1915) are probably lower than the actual predevelopment water levels and, with this understanding, can be used as a guide to calibration at steady-state predevelopment conditions. Therefore, simulated predevelopment water levels should be higher than those reported in the early 1900's.

A comparison of the measured water levels reported in 1915 to the simulated water levels in cells corresponding to well locations where measurements were taken indicates that the simulated water levels are generally higher (RMS error of $60 \mathrm{ft}$ ) than measured water levels (fig. 11 and table 4), as expected. The simulated water levels that were less than measured water levels were outside the focus of the study area, the lower Fox River Valley.

Water levels in the upper aquifer were qualitatively checked to ensure that they resembled expected water levels. A number of cells were simulated as unsaturated in the upper aquifer. Unsaturated conditions are expected along the Silurian escarpment and in the southeastern part of the study area where the upper aquifer is thin and overlies the confining unit. Simulated unsaturated cells in the upper aquifer at predevelopment were not acceptable in the lower Fox River Valley under steady-state conditions. The calibrated model contained no unsaturated cells in the lower Fox River Valley.

The mass balance error, which compares simulated inflow to the ground-water system with simulated outflow, for the steady-state predevelopment simulation is 0.00 percent. Downward flow from the upper aquifer to the sandstone aquifer accounts for most of the simulated flow into the sandstone aquifer: 88.6 percent originates from active cells in the upper aquifer, and 6.1 percent originates from constant-head cells (fig. 13) in the upper aquifer. The remaining simulated flow into the sandstone aquifer is from constant-head cells in the sandstone aquifer at the southern boundary of the model $(3.6 \%)$ and infiltration of precipitation (recharge) where the upper aquifer is unsaturated $(1.7 \%)$. Simulated flow out of the sandstone aquifer is divided between flow to the upper aquifer $(75.2 \%)$, flow to constant-head cells in the upper aquifer $(19.9 \%)$, and flow to constant-head cells in the sandstone aquifer at the southern boundary (5.0\%).

\section{Transient Simulation}

The response of aquifer water levels to development of the sandstone aquifer was simulated under transient conditions. A transient simulation is required because water levels in the sandstone aquifer have not 


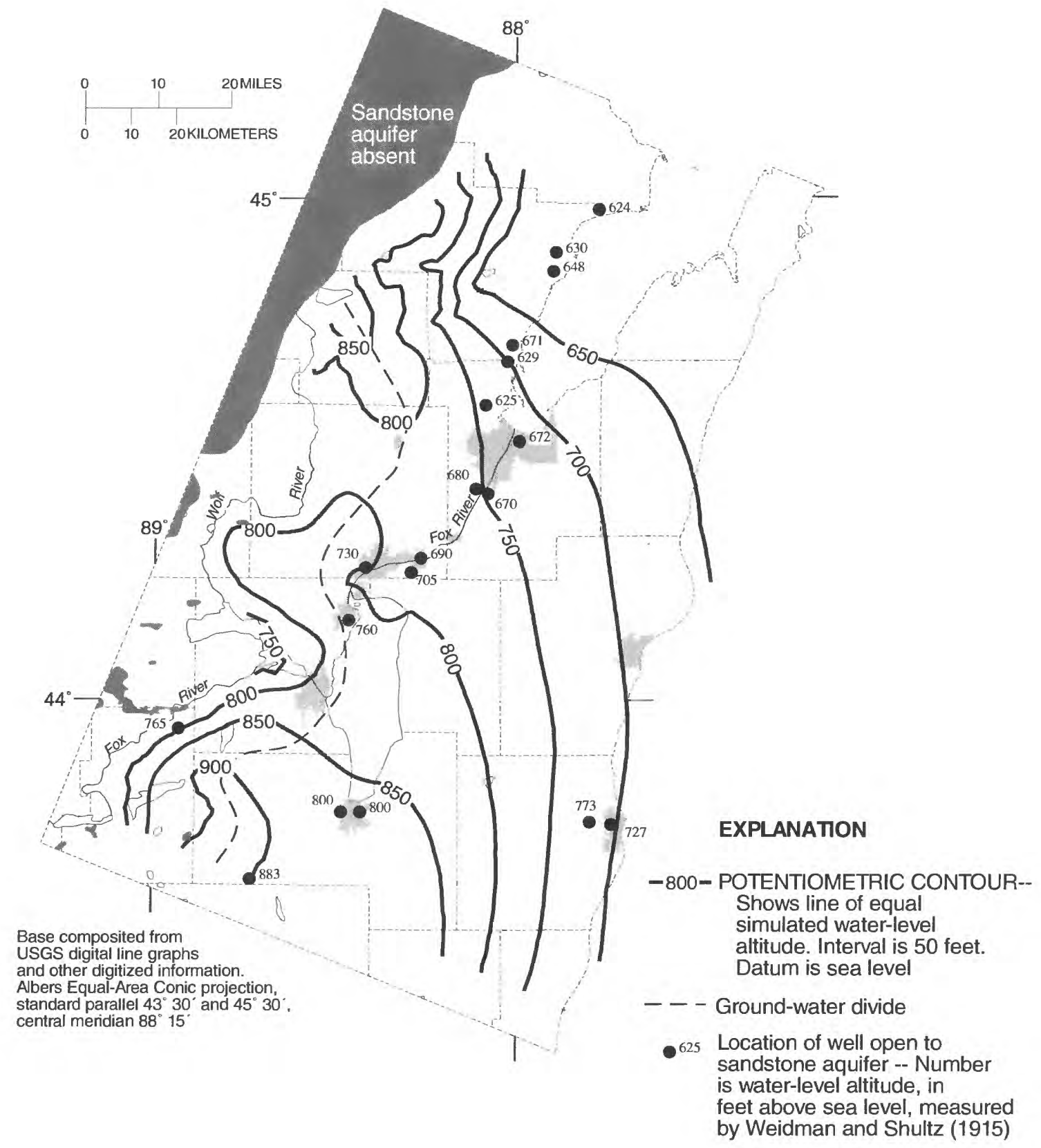

Figure 11. Simulated predevelopment potentiometric surface in the sandstone aquifer, northeastern Wisconsin. 


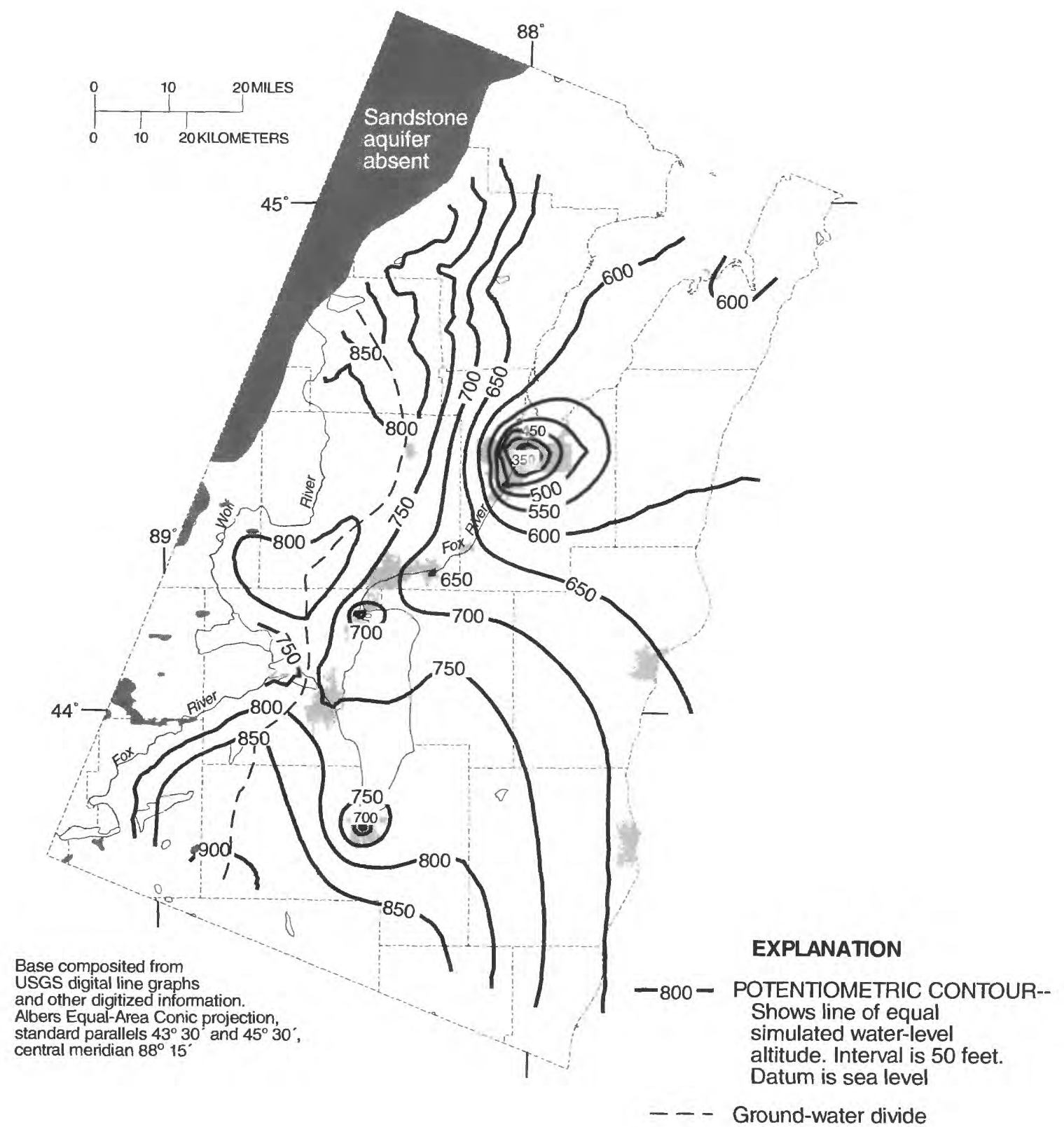

Figure 12A. Simulated potentiometric surface in the sandstone aquifer, northeastern Wisconsin, 1957. 


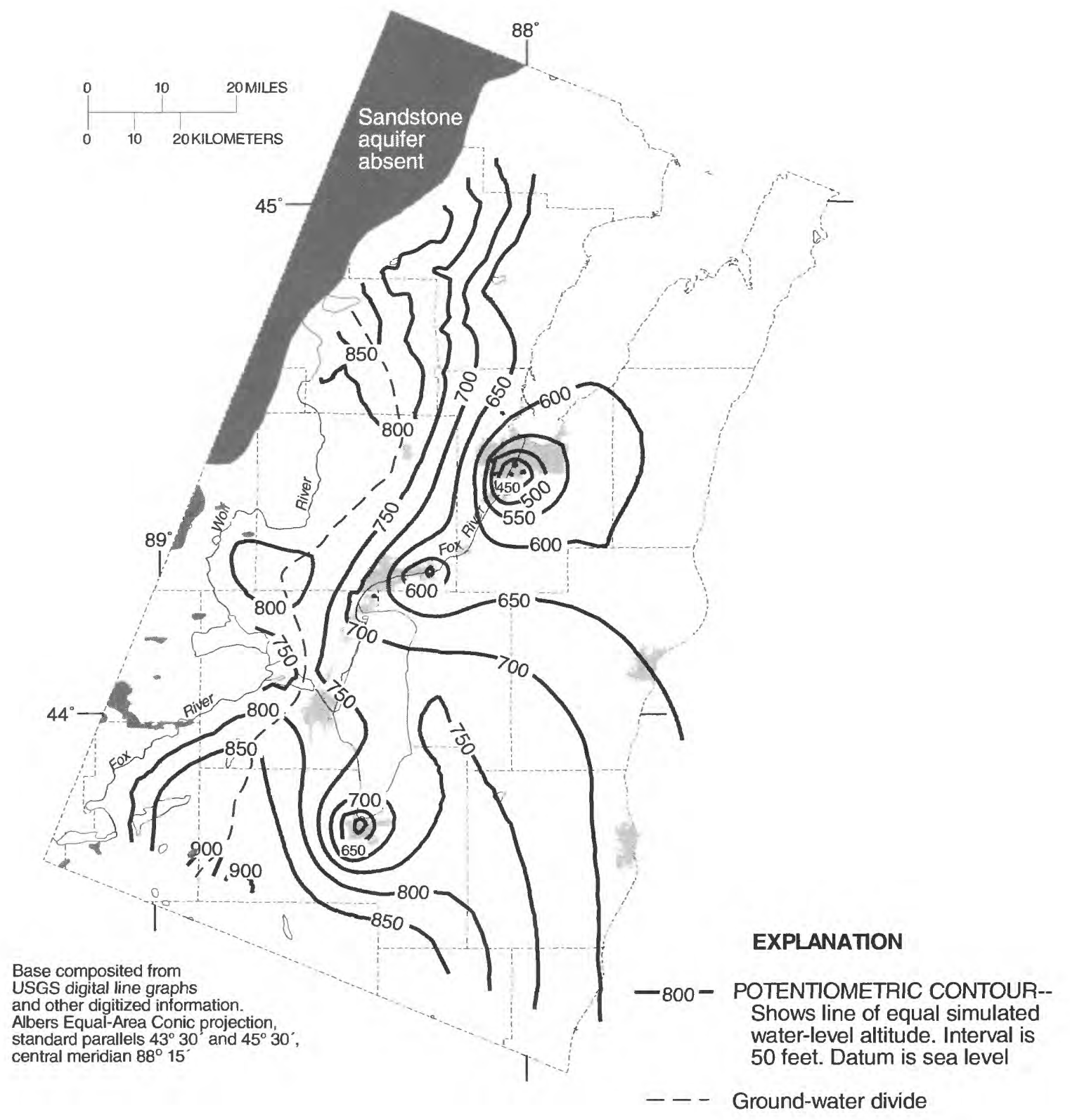

Figure 12B. Simulated potentiometric surface in the sandstone aquifer, northeastern Wisconsin, 1990. 
Sources of simulated flow into sandstone aquifer

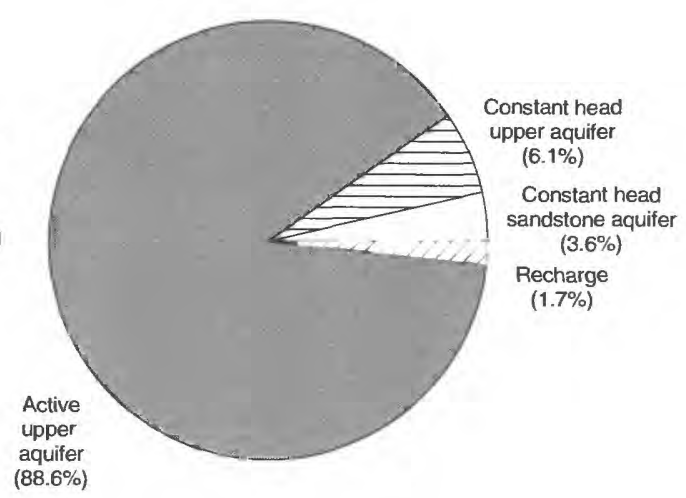

Sinks of simulated flow from sandstone aquifer

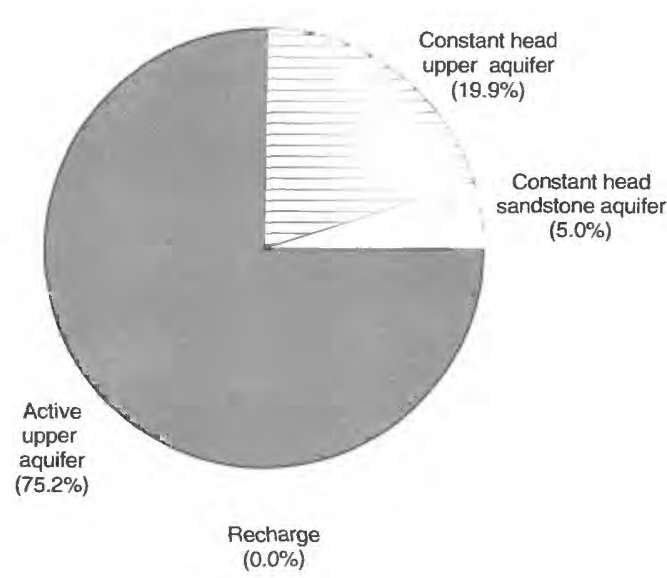

Predevelopment (steady-state simulation with no pumping from wells)

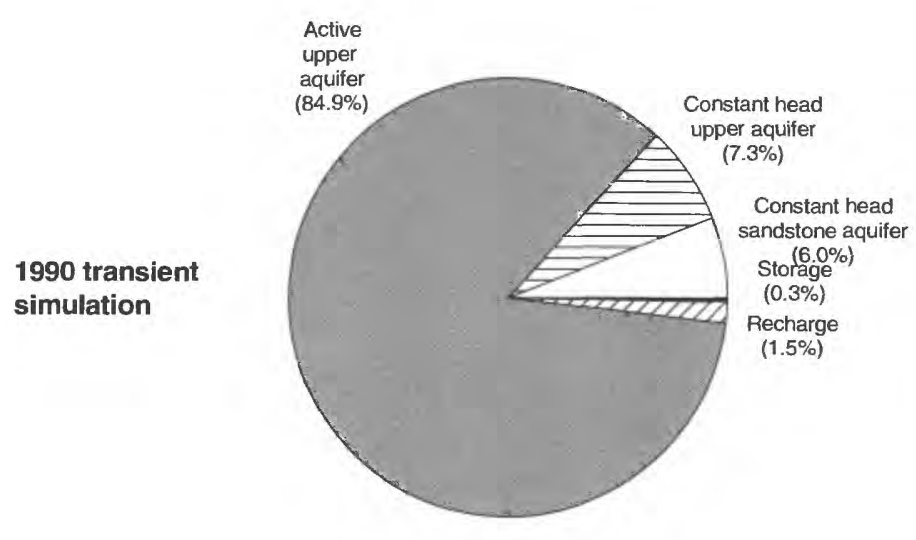

Predevelopment total flow in sandstone aquifer $=45.0$ million gallons per day

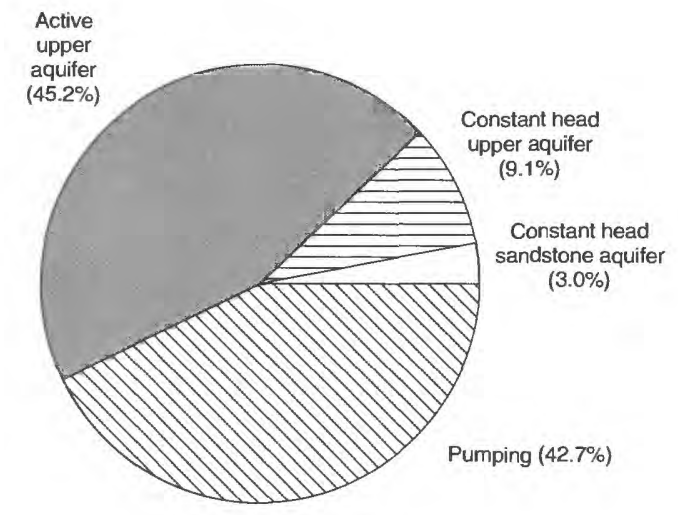

Recharge $(0.0 \%)$ Storage $(<0.1 \%)$

Predevelopment total flow in sandstone aquifer $=62.1$ million gallons per day

Figure 13. Simulated water budgets for the sandstone aquifer at predevelopment and 1990, northeastern Wisconsin. 
A. Simulated 1957 water levels minus measured water levels (transient simulation)

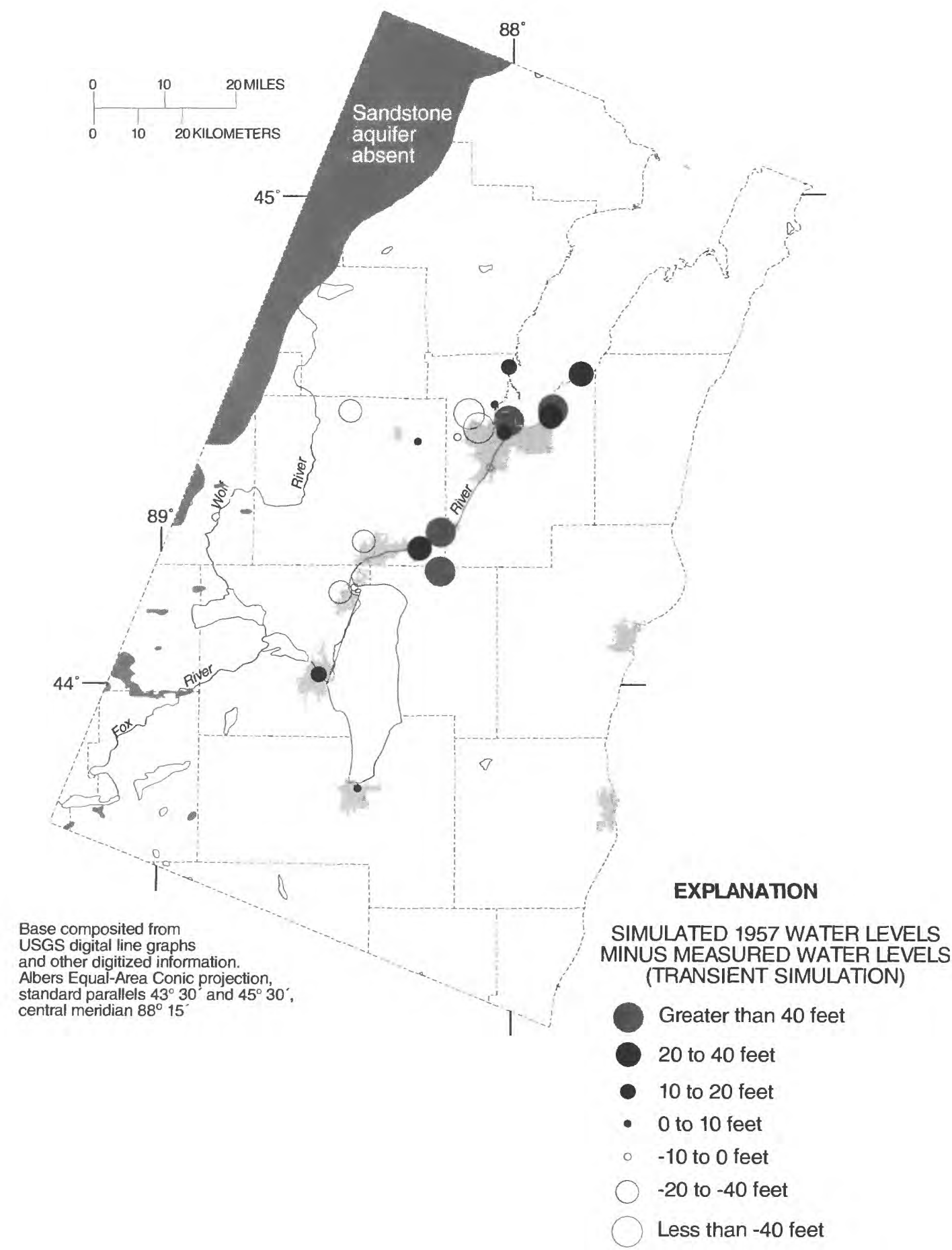

Figure 14A. Differences between measured and simulated water levels in the sandstone aquifer, northeastern Wisconsin, 1957. 


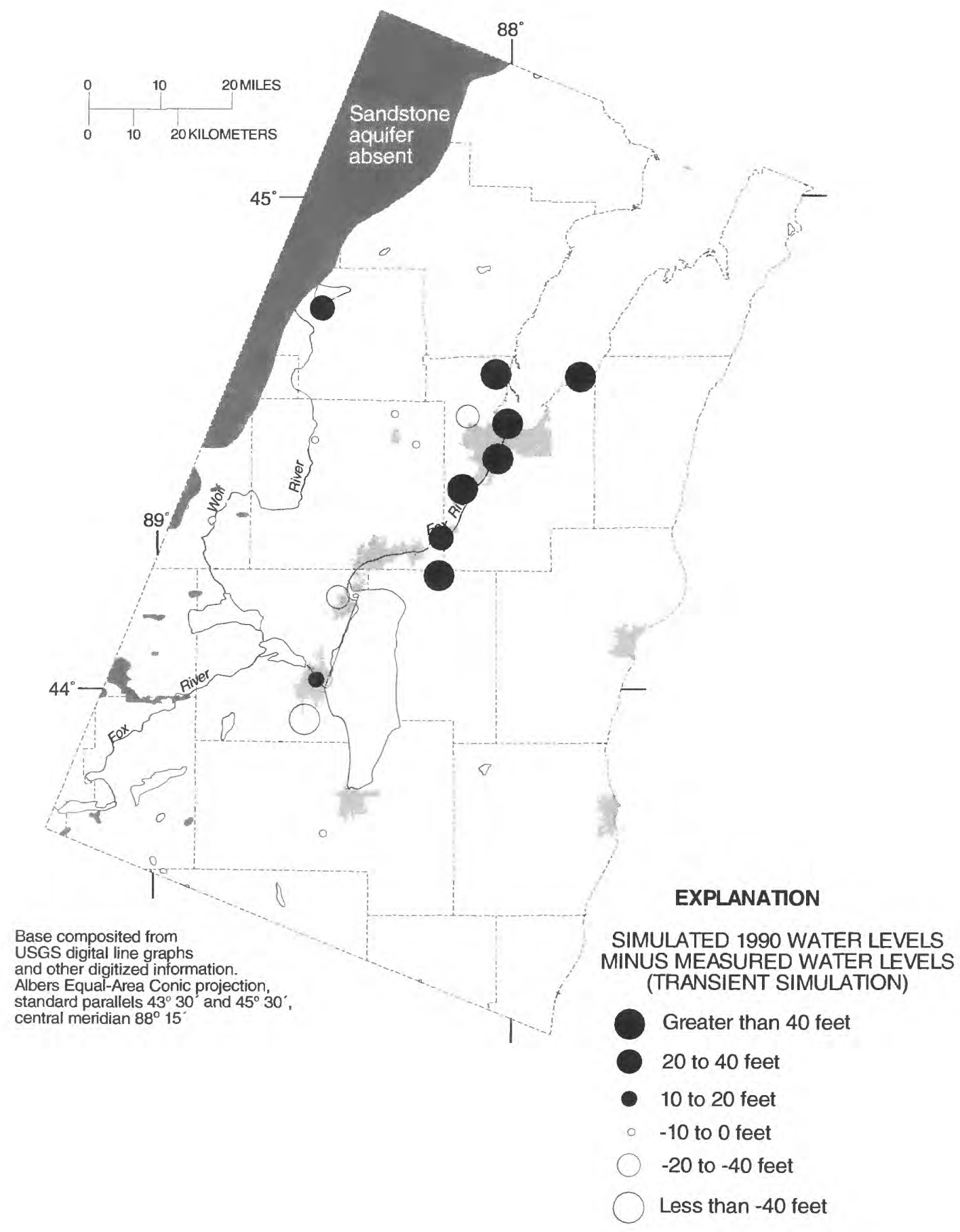

Figure 14B. Differences between measured and simulated water levels in the sandstone aquifer, northeastern Wisconsin, 1990. 


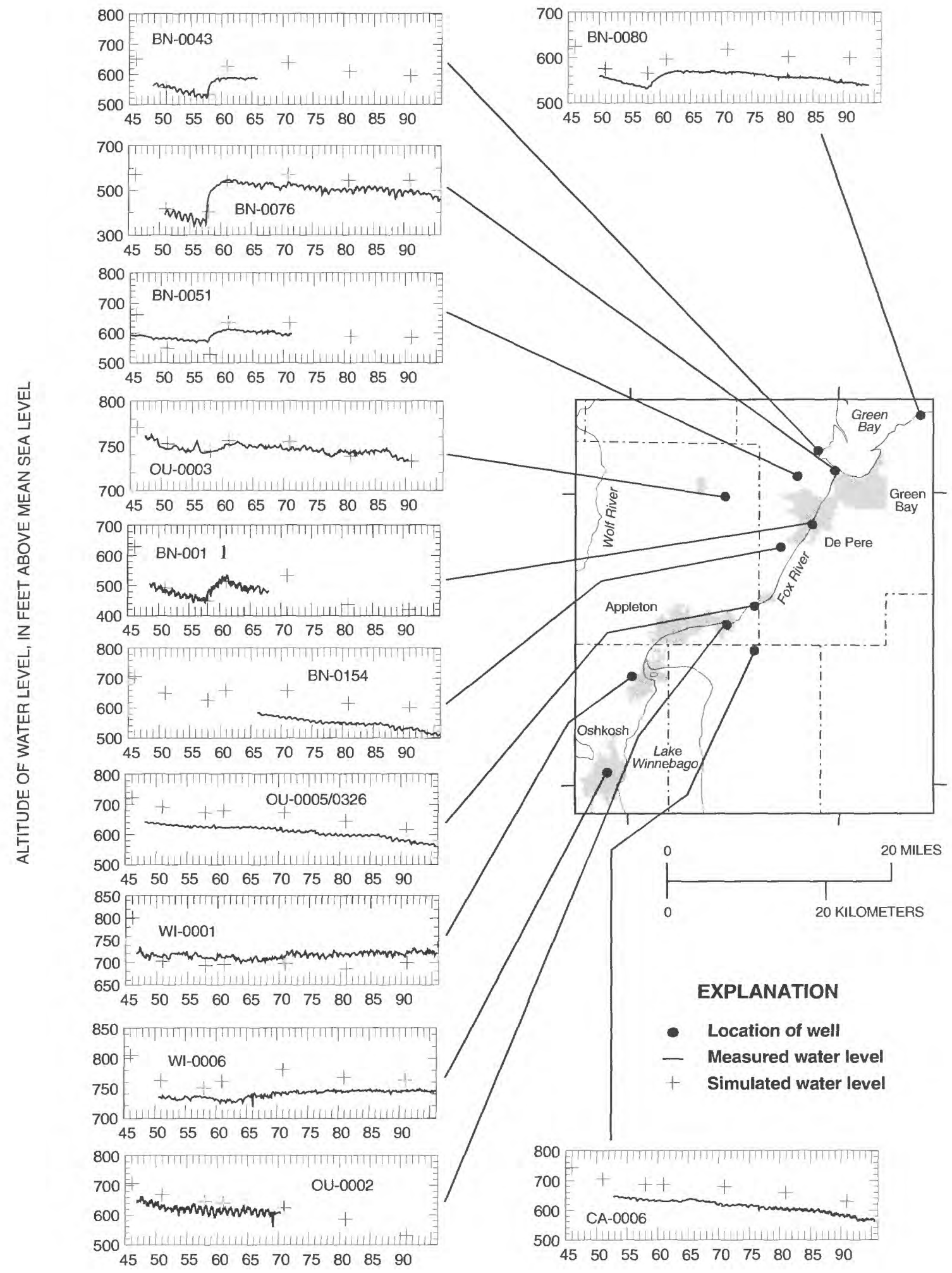

Figure 15. Measured and simulated water levels at selected sites in northeastern Wisconsin, 1945-90. 
Table 4. Measured and simulated water levels, and root mean square error of simulated water levels for steady-state predevelopment simulation, northeastern Wisconsin

\begin{tabular}{lccccc}
\hline \multicolumn{1}{c}{ Well location } & Model row & $\begin{array}{c}\text { Model } \\
\text { column }\end{array}$ & $\begin{array}{c}\text { Altitude of measured } \\
\text { water level (feet) }\end{array}$ & $\begin{array}{c}\text { Altitude of } \\
\text { simulated water } \\
\text { level (feet) }\end{array}$ & $\begin{array}{c}\text { Difference } \\
\text { (feet) }\end{array}$ \\
\hline Little River & 2 & 69 & 624 & 623.4 & -0.6 \\
North Oconto & 4 & 57 & 630 & 616.2 & -13.8 \\
South Oconto & 4 & 59 & 648 & 616.1 & -31.9 \\
Little Suamico & 8 & 55 & 671 & 677.7 & 6.7 \\
Suamico & 10 & 56 & 629 & 706.5 & 77.5 \\
Howard & 17 & 54 & 625 & 738.0 & 113.0 \\
Green Bay & 26 & 79 & 672 & 719.7 & 47.7 \\
West De Pere & 59 & 68 & 680 & 753.3 & 73.3 \\
East De Pere & 59 & 75 & 670 & 747.1 & 77.1 \\
North Kaukauna & 77 & 54 & 690 & 785.9 & 95.9 \\
South Kaukauna & 86 & 52 & 705 & 790.7 & 85.7 \\
Appleton & 94 & 28 & 730 & 801.3 & 71.3 \\
Neenah & 117 & 32 & 760 & 804.2 & 44.2 \\
Sheboygan & 124 & 100 & 727 & 688.2 & -38.8 \\
Kohler & 125 & 99 & 773 & 729.3 & -43.7 \\
Berlin & 130 & 5 & 765 & 786.5 & 21.5 \\
East Fond du Lac & 131 & 79 & 800 & 863.2 & 63.2 \\
West Fond du Lac & 132 & 69 & 800 & 865.4 & 65.4 \\
Waupun & 140 & 37 & 883 & 900.0 & 17.0 \\
Root mean square error: 60.5 feet & & & & & \\
\hline
\end{tabular}

reached steady state; that is, they continue to decline in response to pumping (fig. 3). A transient simulation allows stresses, such as pumping, to change over time. For the transient simulation discussed in this report, the major difference from the steady-state simulation is that the period of time from 1880 to 1990 has been divided into eight stress periods (fig. 9 and appendix A) in which pumping from the sandstone aquifer changes from period to period. Stress periods range in length from 3 years, for the period after the city of Green Bay switched from a ground-water system to a surfacewater system, to 45 years for the first stress period when pumping rates are small. In addition to stresses, storage of water in the aquifers is simulated with storage coefficients, which for the sandstone aquifer will change in cells where the water level in the aquifer falls below the bottom of the confining unit. Recharge and stream and lake stage remain constant during the transient simulation.
Simulated predevelopment water levels in the upper and sandstone aquifers from the steady-state model are used for initial water levels in the transient simulation. Simulated water levels for 1957 and 1990 in the sandstone aquifer were contoured (fig. 12) and compare well with the corresponding contoured measured water levels (fig. 2). The magnitude of the simulated cones of depression in the lower Fox River Valley are similar to the measured cones. The shape of the cone of depression differs because of the contouring method used. The RMS error is 35 and $42 \mathrm{ft}$ in 1957 and 1990, respectively (table 5). For 1957 simulated water levels, the largest difference from measured water levels is near the Green Bay cone of depression, where the simulated water level is $79 \mathrm{ft}$ lower than the measured water level in a nearby observation well (fig. 14A). For 1990 simulated values, the largest difference from measured water levels is also near the Green Bay cone of depression (fig. 14B), where the simulated water level is $69 \mathrm{ft}$ higher than the measured 
Table 5. Root-mean-squared error of simulated water levels for transient simulations, 1957 and 1990

\begin{tabular}{|c|c|c|c|c|c|}
\hline Well name & Row & Col & $\begin{array}{l}\text { Altitude of measured } \\
\text { water level (feet) }\end{array}$ & $\begin{array}{l}1957 \text { Altitude of } \\
\text { simulated water } \\
\text { level (feet) }\end{array}$ & $\begin{array}{l}\text { Difference } \\
\text { (feet) }\end{array}$ \\
\hline $\mathrm{BN}-25 / 22 \mathrm{E} / 14-0080$ & 9 & 92 & 533 & 566.7 & 33.7 \\
\hline $\mathrm{BN}-25 / 21 \mathrm{E} / 07-0078$ & 10 & 61 & 592 & 610.2 & 18.2 \\
\hline BN-24/22E/07-0098 & 12 & 91 & 470 & 524.6 & 54.6 \\
\hline $\mathrm{BN}-24 / 21 \mathrm{E} / 13-0072$ & 15 & 91 & 460 & 499.6 & 39.6 \\
\hline $\mathrm{BN}-24 / 20 \mathrm{E} / 02-0043$ & 18 & 62 & 525 & 533.7 & 8.7 \\
\hline $\mathrm{BN}-24 / 20 \mathrm{E} / 24-0076$ & 21 & 73 & 360 & 404.0 & 44.0 \\
\hline $\mathrm{BN}-24 / 20 \mathrm{E} / 18-0013$ & 26 & 51 & 671 & 592.5 & -78.5 \\
\hline $\mathrm{BN}-24 / 20 \mathrm{E} / 25-0009$ & 28 & 73 & 270 & 289.5 & 19.5 \\
\hline BN-24/20E/29-0051 & 31 & 58 & 575 & 527.1 & -47.9 \\
\hline $\mathrm{BN}-24 / 19 \mathrm{E} / 35-0016$ & 40 & 50 & 620 & 615.5 & -4.5 \\
\hline $\mathrm{BN}-23 / 20 \mathrm{E} / 22-0011$ & 49 & 73 & 455 & 447.2 & -7.8 \\
\hline OU-24/17E/08-0170 & 51 & 7 & 790 & 765.1 & -24.9 \\
\hline OU-23/18E/02-0003 & 53 & 30 & 742 & 743.4 & 1.4 \\
\hline OU-21/19E/04-0005 & 71 & 63 & 625 & 673.4 & 48.4 \\
\hline OU-21/18E/24-0002 & 79 & 55 & 615 & 645.1 & 30.1 \\
\hline CA-20/19E/02-0006 & 86 & 71 & 635 & 686.8 & 51.8 \\
\hline OU-21/17E/15-0029 & 87 & 25 & 781 & 749.6 & -31.4 \\
\hline WI-20/17E/22-0020 & 113 & 30 & 660 & 652.6 & -7.4 \\
\hline WI-20/17E/20-0001 & 115 & 23 & 720 & 693.3 & -26.7 \\
\hline WI-18/16E/23-0006 & 124 & 31 & 734 & 749.6 & 15.6 \\
\hline FL-15/17E/11-0012 & 131 & 76 & 691 & 695.4 & 4.4 \\
\hline \multicolumn{6}{|c|}{1957 root-mean-squared error: 34.9 feet } \\
\hline Well name & Row & Col & $\begin{array}{l}\text { Altitude of measured } \\
\text { water level (feet) }\end{array}$ & $\begin{array}{l}1990 \text { Altitude of } \\
\text { simulated water } \\
\text { level (feet) }\end{array}$ & $\begin{array}{l}\text { Difference } \\
\text { (feet) }\end{array}$ \\
\hline $\mathrm{BN}-25 / 22 \mathrm{E} / 14-0080$ & 9 & 92 & 545 & 598.2 & 53.2 \\
\hline $\mathrm{BN}-25 / 20 \mathrm{E} / 14-0890$ & 11 & 56 & 589 & 640.8 & 51.8 \\
\hline SH-27/16E/34-0027 & 12 & 3 & 831 & 864.3 & 33.3 \\
\hline BN-24/20E/24-0076 & 21 & 73 & 490 & 545.0 & 55.0 \\
\hline BN-24/20E/18-0013 & 26 & 51 & 665 & 626.4 & -38.6 \\
\hline OU-24/18E/08-0416 & 40 & 14 & 809 & 803.7 & -5.3 \\
\hline BN-23/20E/14-0109 & 41 & 76 & 350 & 407.7 & 57.7 \\
\hline OU-23/18E/02-0003 & 53 & 30 & 734 & 732.6 & -1.4 \\
\hline $\mathrm{BN}-22 / 19 \mathrm{E} / 01-0154$ & 63 & 64 & 530 & 599.1 & 69.1 \\
\hline OU-24/18E/34-0380 & 65 & 6 & 762 & 759.0 & -3.0 \\
\hline OU-21/19E/04-0326 & 71 & 63 & 578 & 616.0 & 38.0 \\
\hline CA-20/19E/02-0006 & 86 & 71 & 580 & 629.4 & 49.4 \\
\hline WI-20/17E/20-0001 & 115 & 23 & 720 & 699.5 & -20.5 \\
\hline WI-18/16E/23-0006 & 124 & 31 & 745 & 763.8 & 18.8 \\
\hline WI-17/16E/15-0048 & 127 & 33 & 851 & 791.3 & -59.7 \\
\hline FL-14/17E/06-0659 & 137 & 69 & 765 & 755.4 & -9.6 \\
\hline
\end{tabular}


water level in a nearby observation well. A comparison of simulated and measured water levels for 1957 shows that simulated water levels ranged from $79 \mathrm{ft}$ lower to $55 \mathrm{ft}$ higher than measured water levels (table 5) and that simulated water levels were generally lower than measured water levels in the western part of the study area and higher than measured water levels in the lower Fox River Valley (fig. 14A). In 1990, simulated water levels ranged from $60 \mathrm{ft}$ lower to $69 \mathrm{ft}$ higher than measured water levels (table 5), and simulated water levels were generally higher than measured water levels, especially in the lower Fox River Valley (fig. 14B).

Simulated water levels in the sandstone aquifer were plotted on hydrographs showing the trend in measured water levels in a well to assess how accurately the model simulates changes in water levels over time (fig. 15). The simulated water levels for wells in the Green Bay area follow trends in the hydrographs of measured water levels, especially the response of water levels to the decline in pumping from 1957 to 1960 in wells BN-0076 and BN-0011. The trend of simulated water levels near the Fox Cities is similar to the steady decline in water levels measured in wells OU-0002, CA-0006, OU-0005, and OU-0326. West of Green Bay, simulated water levels accurately track the hydrograph for well OU-0003. The relatively constant water level in well WI-0001 near Oshkosh also is simulated.

Simulated streamflow for 1990 falls within the limits of base flow defined for four of the five selected streams for which baseflow was calculated. The simulated flow in the Suamico River was less than the lower bound of the range of base flow. The low simulated flow in the Suamico River may result from local variations in the hydraulic conductivity of the upper aquifer, leakance of the streambed material, or recharge that was not simulated because data were unavailable in the area. The 1990 simulated flow for the Pensaukee River, the only river of the five streams simulated as a headdependent stream, was slightly higher than the lower bound of baseflow.

Simulated water levels in the sandstone aquifer at the eastern boundary beneath Lake Michigan range from 595 to $645 \mathrm{ft}$ in 1957 and 593 to $645 \mathrm{ft}$ in 1990 . At both times, an upward gradient was simulated from the sandstone aquifer to Lake Michigan, which was simulated with constant heads of $577 \mathrm{ft}$. The decline in simulated water levels at the model-area boundary since predevelopment was calculated to assess the effect of boundaries on simulated water levels in the sandstone aquifer in 1957 and 1990. Large declines in water levels in the aquifer at the boundaries would indicate that model boundaries are affecting simulated water levels in an unreasonable way. Maximum decline in water levels is $8.3 \mathrm{ft}$ at the eastern boundary in 1990 , $17.2 \mathrm{ft}$ at the northern boundary in 1957 , and $1.0 \mathrm{ft}$ at the western boundary in 1990 . Given that the decline in simulated water levels in the cone of depression is more than $400 \mathrm{ft}$, these values at the boundary are considered acceptable. Declines in water levels are relatively small at the western boundary because a groundwater divide is simulated between the Fox and Wolf Rivers (fig. 12). This ground-water divide is similar to the divide reported by Batten and Bradbury (1996, p. 18) except that the simulated divide is approximately 3 mi east of the observed divide. The southern boundary is simulated with constant heads; thus, no decline is simulated in water levels in the sandstone.

The mass balance error for the transient 1990 simulation is 0.04 percent. Simulated flow into the sandstone aquifer is mostly from the upper aquifer: 84.9 percent from active cells in the upper aquifer and 7.3 percent from constant-head cells in the upper aquifer (fig. 13). The remaining simulated flow into the sandstone aquifer is from constant-head cells in the sandstone aquifer at the southern boundary of the model $(6.0 \%)$, infiltration of precipitation (recharge) where the upper aquifer is unsaturated (1.5\%), and storage in the sandstone aquifer $(0.3 \%)$. Upward flow to the upper aquifer (45.2\%) and flow to wells (42.7\%) account for most of the simulated flow out of the sandstone aquifer. The remaining simulated flow out of the sandstone aquifer is to constant head cells in the upper aquifer $(9.1 \%)$ and to constant-head cells in the sandstone aquifer at the southern boundary $(3.0 \%)$.

When the 1990 simulated flow into and out of the sandstone aquifer is compared to the predevelopment flow without pumping (fig. 13), it is clear that flow into the sandstone aquifer must increase to account for the discharge of water at wells. The simulated flow indicates that flow from constant-head cells into the aquifer increases, and flow from storage occurs. The increase in flow from the constant-head cells at the southern boundary is expected and is probably the source of some of the water discharging from wells at the pumping center in the southern part of the study area near Fond du Lac, Wis. Simulating the southern boundary as a no-flow boundary resulted in simulated water levels that were lower than measured water levels near Fond du Lac, and drawdown at the southern no-flow bound- 
ary was unacceptably high. Although the percent of total flow into the sandstone aquifer from recharge and active cells in the upper aquifer for 1990 is less than that at predevelopment, the magnitude of the flows increases because the total flow into the sandstone aquifer is greater in 1990 than at predevelopment. Flow out of the sandstone aquifer to the upper aquifer and constant-head cells in the sandstone aquifer as a percent of total flow is reduced from percent flows at predevelopment because wells discharge water from the aquifer in 1990.

\section{Sensitivity Analysis of Transient Model}

Calibrating a model always presumes some degree of uncertainty about the accuracy of some of the hydrologic input parameters. Sensitivity of the model to changes in selected model input was examined by individually changing aquifer and confining unit hydraulic characteristics and streambed and lakebed leakance within their expected ranges and by observing the resulting changes in simulated water levels and stream flow. The characteristics selected to test for sensitivity were (1) recharge, (2) horizontal hydraulic conductivity of the upper aquifer, (3) horizontal hydraulic conductivity of the sandstone aquifer, (4) the vertical hydraulic conductivity of the confining unit and leakance between the upper and sandstone aquifer where the confining unit is absent, and (5) streambed and lakebed leakance. Storage coefficient and pumping rates were not tested for sensitivity.

Simulated water levels in the sandstone aquifer responded proportionally to changes in recharge; that is, an increase in recharge resulted in an increase in simulated water levels. Changes in recharge from the calibrated value of $0.7 \mathrm{in} / \mathrm{yr}$ resulted in an increased RMS error in 1957 simulated water levels (fig. 16). The RMS error for simulated 1990 water levels increased when recharge was increased from 0.7 to $1.0 \mathrm{in} / \mathrm{yr}$. Because simulated water levels in the sandstone aquifer are generally higher than measured water levels for 1990 , a decrease in recharge from 0.7 to $0.4 \mathrm{in} / \mathrm{yr}$ resulted in a slight improvement in the RMS error, from 41 to $40 \mathrm{ft}$. The number of unsaturated cells simulated in the upper aquifer is inversely proportional to recharge; that is, a decrease in recharge resulted in an increase number of unsaturated cells in the upper aquifer. Decreasing recharge from 0.7 to $0.4 \mathrm{in} / \mathrm{yr}$ resulted in unsaturated conditions in areas of the upper aquifer where saturated conditions are expected. Increasing recharge from 0.7 to $1.0 \mathrm{in} / \mathrm{yr}$ resulted in simulated streamflow in Duck Creek that was higher than the upper bound of base flow. Decreasing recharge resulted in simulated streamflow in the Pensaukee River to be lower than the lower bound of base flow. Simulated streamflow in the Suamico, East, and Fond du Lac Rivers were less sensitive to recharge.

Changes in the horizontal hydraulic conductivity of the upper aquifer result in changes in simulated water levels in the sandstone aquifer and the number of cells in the upper aquifer that become unsaturated. Increasing the horizontal hydraulic conductivity of the upper aquifer from the calibrated value of 3.3 to $6.6 \mathrm{ft} / \mathrm{d}$ resulted in a smaller RMS error in simulated water levels in the sandstone aquifer (fig. 16), but also resulted in more cells in the upper aquifer becoming unsaturated. The majority of unsaturated cells in all simulations were located along the Silurian escarpment on the northeast shore of Lake Winnebago, where unsaturated Silurian dolomite rocks of the upper aquifer are known to exist. However, when the horizontal hydraulic conductivity of the upper aquifer increased, cells in the upper aquifer were simulated in places near the Fox Cities as unsaturated where saturated conditions are expected. Decreasing the horizontal hydraulic conductivity of the upper aquifer results in fewer simulated unsaturated cells, but it also increases RMS errors for simulated water levels in the sandstone aquifer for 1957 and 1990. Simulated streamflow was relatively insensitive to changes in horizontal hydraulic conductivity of the upper aquifer.

As expected, simulated water levels in the sandstone aquifer are most sensitive to changes in the horizontal hydraulic conductivity of the sandstone aquifer (fig. 16). The horizontal hydraulic conductivity of the sandstone aquifer used in calibrating the model resulted in the lowest RMS error for simulated water levels. Doubling or halving the horizontal hydraulic conductivity of the sandstone aquifer resulted in larger RMS errors. Simulated streamflow was relatively insensitive to changes in horizontal hydraulic conductivity of the sandstone aquifer.

Changing the vertical hydraulic conductivity of the confining unit or the leakance between aquifer units where the confining unit is absent increased the RMS error for simulated water levels in the sandstone aquifer. The simulated 1990 water levels were relatively insensitive to a decrease in the vertical hydraulic conductivity of the confining unit and leakance. Simulated 


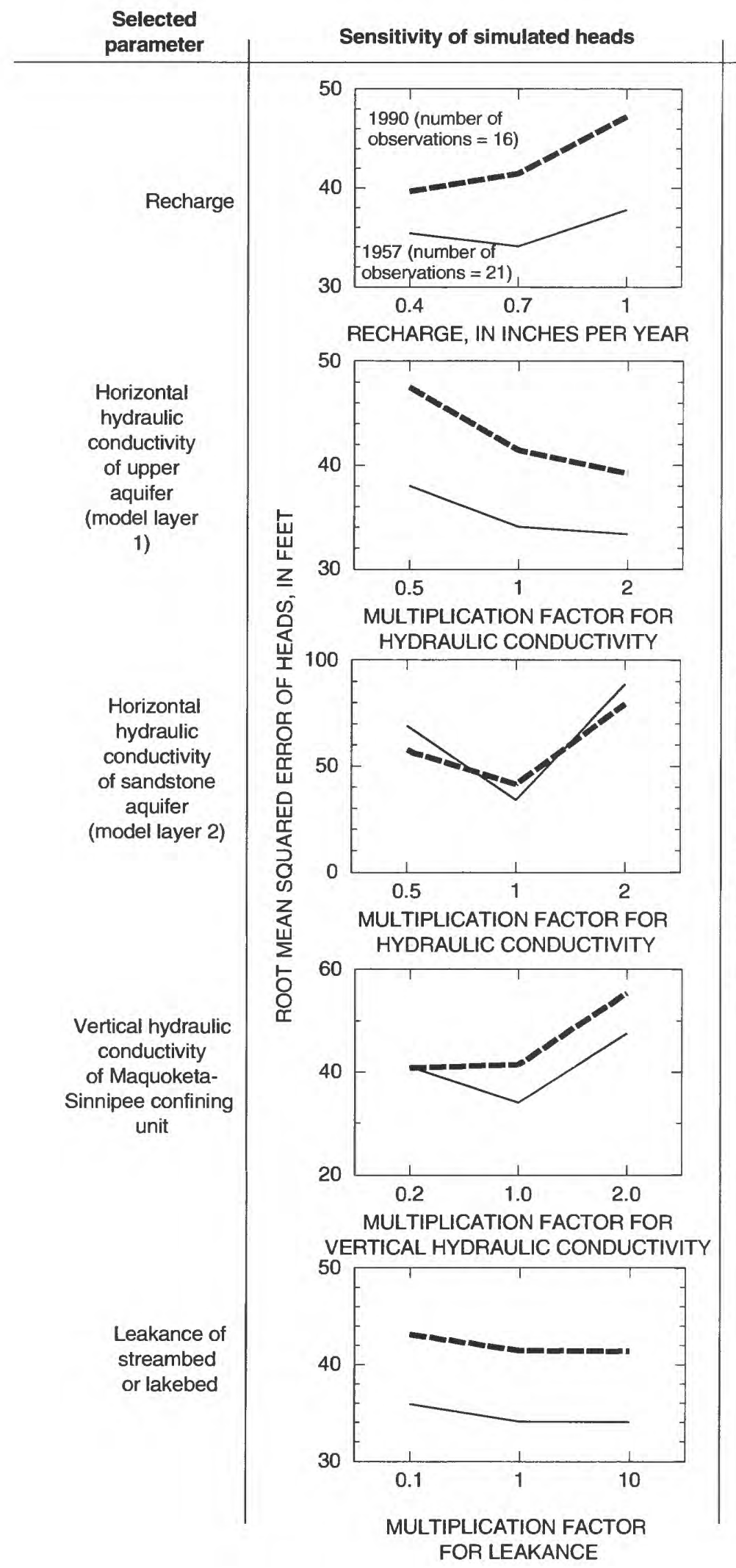

Sensitivity of simulated streamflow
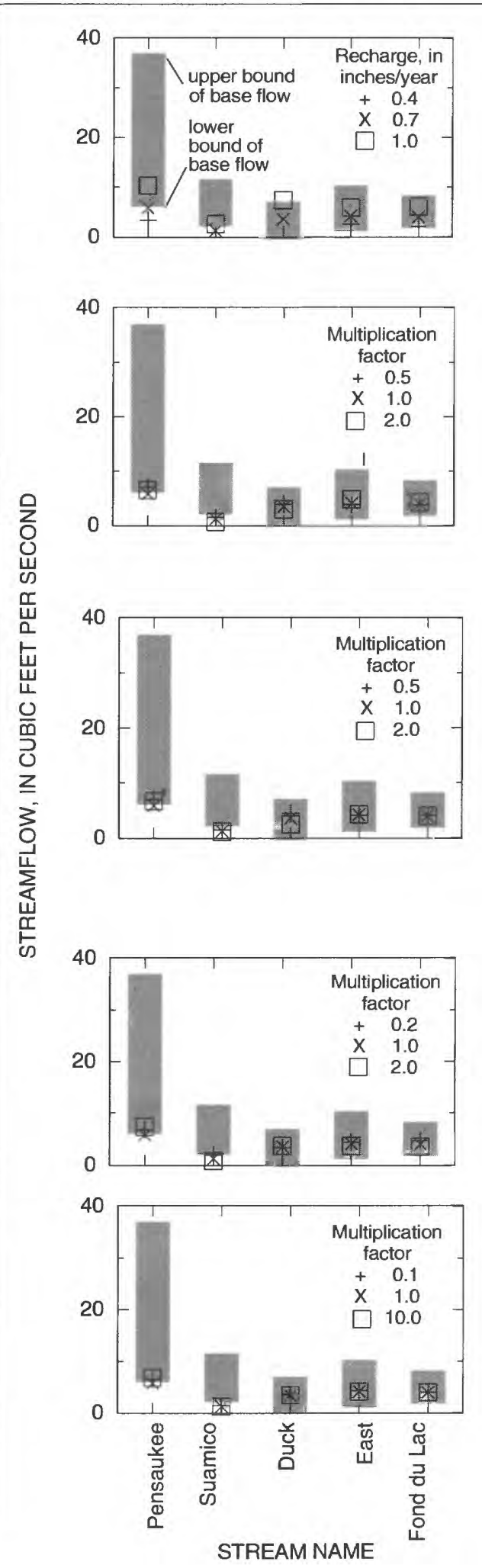

Figure 16. Sensitivity of simulated heads and streamflow to changes in selected model pararmeters of the ground-water-flow model for northeastern Wisconsin. 
streamflow is relatively insensitive to changes in this parameter.

The simulated results were relatively insensitive to changes in streambed and lakebed leakance.

Decreasing leakance resulted in a larger RMS error in simulated water levels in the sandstone aquifer (fig. 16). Increasing the leakance resulted in an improvement of the RMS error by less than $1 \mathrm{ft}$. The flow in the Pensaukee River, the only head-dependent stream used as a calibration target, was less sensitive to changes in leakance than to changes in recharge.

The simulated water levels in the sandstone aquifer are sensitive to changes in values of all model parameters tested. The simulated water levels are most sensitive to changes in the hydraulic conductivity of the sandstone aquifer. Simulated water levels are more sensitive to increases in recharge and vertical leakance between aquifers than to decreases in these parameters.

\section{Discussion of Modeling Results}

Simulating ground-water flow in the sandstone aquifer provides greater understanding of how changes in pumping affect ground-water flow and water levels in the aquifer. Prior to development of the aquifer, potentiometric heads in the aquifer were above land surface in the lower Fox River Valley (Weidman and Schultz, 1915, p. 77). Simulated flow at predevelopment is from southwest to northeast across the central part of the study area (fig. 11). A ground-water divide in the sandstone aquifer is simulated in the western part of the study area where water flows west to the upper Fox River and the Wolf River and east to Lake Michigan. The highest water levels are simulated in the southwestern part of the study area, where constanthead cells constrain water levels near a mapped ground-water divide, and in the northwest. The effect of the lower Fox River and Lake Winnebago on water levels in the sandstone aquifer is minimal because these areas of constant head in the upper aquifer are isolated from the sandstone aquifer by the Maquoketa-Sinnipee confining unit. At the outlet of Lake Winnebago, near Appleton, Wis., the lower Fox River may affect the water levels in the sandstone aquifer because the confining unit is absent in this area (pl. 1). Simulated predevelopment water levels in the sandstone aquifer are approximately 725 and $775 \mathrm{ft}$ in altitude in Green Bay and the Fox Cities areas, respectively.
By 1957, water levels beneath the lower Fox River Valley and the city of Fond du Lac declined because of pumping from the sandstone aquifer. Several cones of depression are simulated for 1957 beneath these areas. The lowest simulated water level in the cone of depression beneath the city of Green Bay is $290 \mathrm{ft}$ above sea level. At this location, the water level dropped approximately $440 \mathrm{ft}$ from the predevelopment level as a result of pumping from the sandstone aquifer in the Green Bay metropolitan area. Two cones are simulated in the Fox Cities area. A cone beneath Kaukauna is simulated with a water level of $645 \mathrm{ft}$ in altitude, which represents a decline of approximately $140 \mathrm{ft}$ from the predevelopment level. The simulated water level in a cone of depression beneath Menasha is $630 \mathrm{ft}$ in altitude, which represents a decline of approximately $170 \mathrm{ft}$ from the predevelopment level. Pumping in the Fond du Lac area resulted in a simulated cone of depression with water levels at $606 \mathrm{ft}$, which represents a $200 \mathrm{ft}$ decline from the predevelopment level.

The direction of ground-water flow in the sandstone aquifer changed because of the effects of pumping from the aquifer. Flow in 1957 is west to east in the northern part of the study area, and wells in the lower Fox River Valley capture much of the flow. Pumping from the aquifer has induced flow from east to west on the eastern side of the cone of depression near Green Bay. Although the ground-water-flow system changed in the lower Fox River Valley, a ground-water divide in the western part of the study area is simulated. This divide extends along the western part of the study area and separates westerly flow to the Wolf and upper Fox Rivers from easterly flow toward Green Bay and Lake Michigan.

After 1957, the city of Green Bay ceased using the sandstone aquifer for its water supply. Aquifer water levels recovered near Green Bay (fig. 15). By 1964 , the reduction in pumping by the city of Green Bay was offset by increased pumping from industry and communities surrounding the city of Green Bay, and water levels again began to decline (fig. 15). By 1990 , simulated water levels beneath the city Green Bay are approximately $500 \mathrm{ft}$ in altitude, which is approximately $200 \mathrm{ft}$ higher than in 1957 . The simulated center of the cone of depression moved southward from beneath the city of Green Bay in 1957 to beneath the area near De Pere (figs. 1 and 12) where the lowest simulated water level in 1990 is $379 \mathrm{ft}$ in altitude, a 10 $\mathrm{ft}$ increase from 1957 water levels. 
Water levels in the Fox Cities area declined approximately $50 \mathrm{ft}$ from 1957 to 1990 . The simulated 1990 cone of depression near Kaukauna is larger than the 1957 cone of depression because simulated water levels have declined in the cone from 645 to $523 \mathrm{ft}$ in altitude, or approximately $120 \mathrm{ft}$, from the 1957 levels. The cone of depression near Menasha (figs. 1 and 12) is not present in 1990 because industrial pumping in the area has decreased since 1957. Simulated water levels in the center of the cone of depression near Fond du Lac in 1990 were approximately $575 \mathrm{ft}$ in altitude, which represents a $30 \mathrm{ft}$ decline from the 1957 level.

Although water levels changed from 1957 to 1990 , the direction of ground-water flow did not change dramatically because the divide in the sandstone aquifer in the western part of the study area in 1957 is present in the 1990 simulation. The flow direction is west to east in the area west of the lower Fox River Valley, and east to west in the area east of the cone of depression in Brown County.

\section{Model Limitations}

The ground-water-flow model provides an efficient way to compile hydrogeologic information of the study area and a framework for site-specific studies. The model cannot, however, provide detailed information about site-specific areas because discretization of space and time limit the application of the model. The model cannot accurately simulate the variation of water levels in areas because the smallest cell size is $1 / 16 \mathrm{mi}^{2}$ and the hydrologic properties are assumed to be homogeneous within each cell. Furthermore, the hydrologic properties that were assigned at this scale may not be supported by field data collected at this scale.

The long-term response of ground-water levels and flow to changes in pumping rates from the sandstone aquifer is simulated. Diurnal changes in water levels from pumping conditions during the day and non-pumping conditions during the night or seasonal changes cannot be simulated because pumping is constant during a stress period and stress periods range from 3 to 45 years in length.

The model may not accurately simulate water levels in wells that are not open to the entire thickness of the sandstone aquifer because wells are assumed to be open to the entire thickness. In addition, lateral variation in the hydrologic properties of the aquifers and confining unit, with the exception of thickness, were not simulated. The sandstone aquifer was divided into two zones of differing horizontal hydraulic conductivity.

The model simulates water levels in the upper aquifer, but a rigorous evaluation of the accuracy of these simulated water levels was not performed during calibration. The heterogeneity of the unconsolidated deposits was not simulated because the focus of the study was the underlying sandstone aquifer. Before using the water levels simulated in the upper aquifer for planning purposes, the historical simulated water levels would need to be compared to historical measured water levels to evaluate the accuracy of the model in simulating conditions in the upper aquifer.

The southern boundary was simulated with constant heads in the sandstone aquifer. The constant heads constrain the water levels at the southern boundary and affect water levels near the boundary and the city of Fond du Lac. Use of simulated water levels in this area should be interpreted realizing the possible effects of this constraint.

The solution to the model is not unique in that any number of reasonable variations in the representation of the ground-water-flow system used in the model might produce equally acceptable results. Nevertheless, the model is a versatile tool that can be used to help understand the ground-water-flow system, to simulate the response of water levels to historical and projected changes in pumping rates, and to evaluate the needs for additional information about the groundwater-flow system that would improve the representation of the system.

\section{POSSIBLE MODEL REVISIONS AND ADDITIONAL DATA NEEDS}

As with most models, the ground-water-flow model for northeastern Wisconsin could be improved with additional collection and interpretation of hydrogeologic data. As new data become available, the model could be updated and recalibrated. The following is a list of hydrogeologic data collection needs that would increase the utility of the ground-water-flow model:

1. The extent and hydrologic properties of the Maquoketa-Sinnipee confining unit are not well understood. The vertical hydraulic conductivity of this unit and its lateral variability need to be documented. The confining properties of the Sinnipee Group near its western extent are not 
known, and the uncertainty about these properties affects the ability of the model to simulate recharge to the underlying sandstone aquifer.

2. To accurately simulate the effect of pumping from the sandstone aquifer on streams and lakes, the following types of data would have to be collected, interpreted, and input into the model: (a) the lateral and vertical variation in the horizontal hydraulic conductivity and storage coefficient of the upper aquifer, which includes both the unconsolidated and consolidated material;

(b) estimates of streambed and lakebed leakance based on measurements made in the study area; and (c) detailed streamflow measurements to compare to simulated flows.

3. Measurement of water levels in the sandstone aquifer east of the lower Fox River Valley would provide important points for further model calibration. Water levels in the sandstone aquifer east of the lower Fox River Valley are not affected by surface-water features and could be used to improve calibration areally.

4. Ground-water withdrawals by industrial and commercial users could be verified and updated. These withdrawals are compiled by the USGS with data provided the Wisconsin Public Services Commission (PSC). At this time, industrial and commercial withdrawals are not verified by the USGS or PSC.

5. Spatial and temporal variations in recharge were not available for simulating recharge to the ground-water-flow system. Data collection that can quantify areal recharge variations within the study area is needed. Analysis of this data could include incorporating measurements of precipitation at several sites within the study area with vertical hydraulic conductivity or infiltration estimates over the study area.

\section{SUMMARY}

The study described in this report was initiated because of concern over declining water levels in the sandstone aquifer in the lower Fox River Valley between Lake Winnebago and Green Bay, Wis. Cones of depression have resulted from pumping from the aquifer in three areas: the Green Bay Metropolitan, Fox Cities, and Fond du Lac areas. Most industries and municipalities in the lower Fox River Valley withdraw ground water from the sandstone aquifer for their water supply. The sandstone aquifer consists of sandstones and carbonates. It is underlain by Precambrian crystalline rock that is assumed to be impermeable and overlain by the Maquoketa-Sinnipee confining unit in the eastern part of the study area. Overlying the sandstone aquifer in the western part of the study area and the confining unit in the east is the upper aquifer, which consists of unconsolidated deposits and dolomites. All units thicken to the east. Major surface-water bodies are in hydraulic connection with the upper aquifer.

Flow within the upper aquifer is from topographically high recharge areas to topographically low discharge areas, which commonly contain streams or lakes. Recharge is from precipitation infiltrating into the upper aquifer. Ground water in the upper aquifer discharges to streams, lakes, and wells. Flow in the sandstone aquifer is from the western part of the study area (where the aquifer is not overlain by the confining unit) to the east (where ground water discharges to the upper aquifer because of upward gradients or directly discharges to land surface by wells). Flow between the upper and sandstone aquifers is limited in the eastern part of the study area by the Maquoketa-Sinnipee confining unit.

Well tests indicate that the Sinnipee Group acts as a confining unit that hydraulically isolates surface water from ground water in the sandstone aquifer. Water in the sandstone and Sinnipee Group-dated by use of tritium analysis - is more than 30 years old, which indicates that this water was not recently recharged. The results of an aquifer test where water was pumped from the sandstone aquifer in a well near Fond du Lac, Wis., indicate the Sinnipee Group acts as a confining unit because water levels in the upper aquifer above the Sinnipee Group did not respond to pumping.

The USGS three-dimensional finite-difference ground-water-flow code MODFLOW was used to develop a model that could be used to improve the understanding of the hydrogeology of the sandstone aquifer. The model also can be used as a tool to simulate contributing areas of wells and the response of water levels to projected pumping of the sandstone aquifer.

The extent of the model area was chosen to include the pumping centers of Green Bay in the north, Fond du Lac in the south, and the upper Fox and Wolf Rivers in the west. The eastern boundary was chosen to be sufficiently east of the pumping centers so that the 
effects of pumping would be minimal at this boundary. The upper model layer represents the upper aquifer and the lower model layer represents the sandstone aquifer. Streams and lakes were simulated as constant-head cell and head-dependent cells in the upper aquifer. A constant hydraulic conductivity of $3 \mathrm{ft} / \mathrm{d}$ was used to simulate the hydraulic property of the upper aquifer. Boundary conditions in the upper aquifer are headdependent, constant head or no flow depending on whether a stream or lake intersects the grid at the boundary. Head-dependent conditions are found only where surface-water bodies are present and are not underlain by the confining unit.

The sandstone aquifer is simulated with two hydraulic conductivities, 1.5 and $3.0 \mathrm{ft} / \mathrm{d}$; the higher hydraulic conductivity is used in the western part of the model area. Boundary conditions are no-flow except along the southern boundary where constant heads are assigned.

Flow in the confining unit is not simulated. Instead, vertical flow between the upper and sandstone aquifers is simulated by use of vertical conductance, which is proportional to the leakance or the quotient of vertical hydraulic conductivity $(0.000035 \mathrm{ft} / \mathrm{d})$ of the confining unit divided by the thickness of the confining unit. Where the confining unit is absent, a leakance value of $0.0015 \mathrm{~d}^{-1}$ was assigned.

A recharge rate of $0.7 \mathrm{in} / \mathrm{yr}$ was applied to the water table and remained constant over time and space. The time period for the simulation was divided into eight pumping stress periods to simulate development of the sandstone aquifer over time.

The ground-water-flow model was calibrated to measured water levels in the sandstone aquifer approximately at predevelopment, 1957, and 1990. The simulated water-level contours compare well with measured water level contours. Simulated water levels show trends in water levels over time that are similar to trends in hydrographs of measured water levels. Simulated flow to streams was within the range of base flow calculated for selected streams. Simulated water levels in the sandstone aquifer are most sensitive to changes in the hydraulic conductivity of the sandstone aquifer.

Most 1990 simulated flow into the sandstone aquifer originates from the upper aquifer. Flow out of the sandstone aquifer is primarily upward flow to the upper aquifer and discharge to wells.

The flow system in the sandstone aquifer has changed over time from flowing west to east or northeast to flowing from west to the cone of depression in the sandstone aquifer underlying the lower Fox River Valley. A ground-water divide, present in the western part of the study area, was simulated from predevelopment to 1990. Water levels in the Green Bay area and Fox Cities area have declined approximately 430 and $200 \mathrm{ft}$, respectively, from predevelopment to 1990 .

\section{REFERENCES CITED}

Batten, W.G., and Bradbury, K.R., 1996, Regional groundwater flow system between the Wolf and Fox Rivers near Green Bay, Wisconsin: Wisconsin Geological and Natural History Survey Information Circular 75, $28 \mathrm{p}$.

Bradbury, K.R., 1991, Tritium as an indicator of groundwater age in central Wisconsin: Ground Water, v. 29, no. 3, p. 398-404.

Chamberlain, T.C., 1878, Geology of eastern Wisconsin, in Geology of Wisconsin, Survey of 1873-1877: Wisconsin Geological and Natural History Survey, v. 2, pt. 2, p. 95-405.

Clayton, Lee, Attig, J.W., Michelson, D.M., and Johnson, M.D., 1991, Glaciation of Wisconsin: Wisconsin Geological and Natural History Survey Educational Series $36,4 \mathrm{p}$.

Drescher, W.J., 1953, Ground-water conditions in artesian aquifers in Brown County, Wisconsin: U.S. Geological Survey Water-Supply Paper 1190, 49 p.

Emmons, P.J., 1987, An evaluation of the bedrock aquifer system in northeastern Wisconsin: U.S. Geological Survey Water-Resources Investigations Report 85-4199, $48 \mathrm{p}$.

Environmental Systems Research Institute Inc., 1991, Arc/ Info User's Guide, 6.0, Surface Modeling with TIN: Redlands, Calif. [variously paginated].

Farrand, W.R., Richmond, G.M., and Fullerton, D.S., 1984, Quaternary geologic map of the Lake Superior $4^{\circ} \times 6^{\circ}$ quadrangle, United States and Canada: U.S. Geological Survey Miscellaneous Investigations Series Map I-1420(NL-16), scale 1:1,000,000.

Feinstein, D.T., 1987, A three-dimensional model of flow to the sandstone aquifer in northeastern Wisconsin with discussion of contamination potential: Madison, University of Wisconsin, M.S. Thesis, 240 p.

Feinstein, D.T., and Anderson, M.P., 1987, Recharge to and potential for contamination of an aquifer system in northeastern Wisconsin: Madison, University of Wisconsin Water Resources Center Technical Report WIS WRC 87-01, $112 \mathrm{p}$.

Holmstrom, B.K, Kammerer, P.A., Jr., and Ellefson, B.R., 1995, Water resources data, Wisconsin, water year 1994: U.S. Geological Survey Water-Data Report WI-94-1, p. 257. 
Kernodle, J.M., McAda, D.P., and Thorn, C.R., 1995, Simulation of ground-water flow in the Albuquerque Basin, central New Mexico 1901-1994, with projections to 2020: U.S. Geological Survey Water-Resources Investigations Report 94-4251, $114 \mathrm{p}$.

Knowles, D.B., 1964, Ground-water conditions in the Green Bay area, Wisconsin, 1950-60: U.S. Geological Survey Water-Supply Paper 1669-J, 37 p.

Knowles, D.B., Dreher, F.C., and Whetsone, G.W., 1964, Water resources of the Green Bay area, Wisconsin: U.S. Geological Survey Water-Supply Paper 1499-G, $67 \mathrm{p}$.

Krohelski, J.T., 1986, Hydrogeology and ground-water use and quality, Brown County, Wisconsin: Wisconsin Geological and Natural History Survey Information Circular 57, $42 \mathrm{p}$.

Krohelski, J.T., Bradbury, K.R., Hunt, R.J. and Swanson, S.K. in press, Numerical simulation of ground-water flow in Dane County, Wisconsin: Wisconsin Geological and Natural History Survey Information Bulletin.

LeRoux, E.F., 1957, Geology and ground-water resources of Outagamie County, Wisconsin: U.S. Geological Survey Water-Supply Paper 1421, 57 p.

Linebeck, J.A., Bleuer, N.K., Mickelson, D.M., Farrand, W.R., and Gold thwait, R.P., 1983, Quaternary geologic map of the Chicago $4^{\circ} \times 6^{\circ}$ quadrangle, United States: U.S. Geological Survey Miscellaneous Investigations Series Map I-1420(NK-16), scale 1:1,000,000.

Mai, H., and Dott, R.H., Jr., 1985, A subsurface study of the St. Peter Sandstone in southern and eastern Wisconsin: Wisconsin Geological and Natural History Information Circular 47, $26 \mathrm{p}$.

Mandle, R.J., and Kontis, A.L., 1992, Simulation of regional ground-water flow in the Cambrian-Ordovician aquifer system in the northern Midwest, United States:

U.S. Geological Survey Professional Paper 1405-C, $97 \mathrm{p}$.

McDonald, M.G., and Harbaugh, A.W., 1988, A modular three-dimensional finite-difference ground-water flow model: U.S. Geological Survey Techniques of WaterResources Investigations, book 6, chap. A 1 [variously paginated].

Need, E.A., 1985, Pleistocene geology of Brown County, Wisconsin: Wisconsin Geological and Natural History Information Circular 48, 19 p.
Newport, T.G., 1962, Geology and ground-water resources of Fond du Lac County, Wisconsin: U.S. Geological Survey Water-Supply Paper 1604, 52 p.

Olcott, P.G., 1966, Geology and water resources of Winnebago County, Wisconsin: U.S. Geological Survey Water-Supply Paper 1814, 61 p.

Robertson, D.M., and Saad, D.A., 1996, Water-quality assessment of the Western Lake Michigan Drainagesanalysis of available information on nutrients and suspended sediment, water years 1971-90: U.S. Geological Survey Water-Resources Investigations Report 96-4012, 165 p.

Saad, D.A., 1996, Ground-water quality in the western part of the Cambrian-Ordovician aquifer in the western Lake Michigan Drainages, Wisconsin and Michigan: U.S. Geological Survey Water-Resources Investigations Report 96-4231, 40 p.

Siegel, D.I., 1989, Geochemistry of the Cambrian-Ordovician aquifer system in the Northern Midwest, United States: U.S. Geological Survey Professional Paper 1405-D, 76 p.

Weidman, Samuel, and Schultz, A.R., 1915, The underground and surface water supplies of Wisconsin: Wisconsin Geological and Natural History Survey Bulletin $35,664 \mathrm{p}$.

Wisconsin Geological and Natural History Survey, 1981, Geological map of Wisconsin: digital data compiled at 1:500,000 scale.

Young, H.L, 1992a, Summary of ground-water hydrology of the Cambrian-Ordovician aquifer system in the northern Midwest, United States: U.S. Geological Survey Professional Paper 1405-A, 55 p.

1992b, Hydrogeology of the Cambrian-Ordovician aquifer system in the northern Midwest, United States: U.S. Geological Survey Professional Paper 1405-B, $99 \mathrm{p}$. 
APPENDIX A 


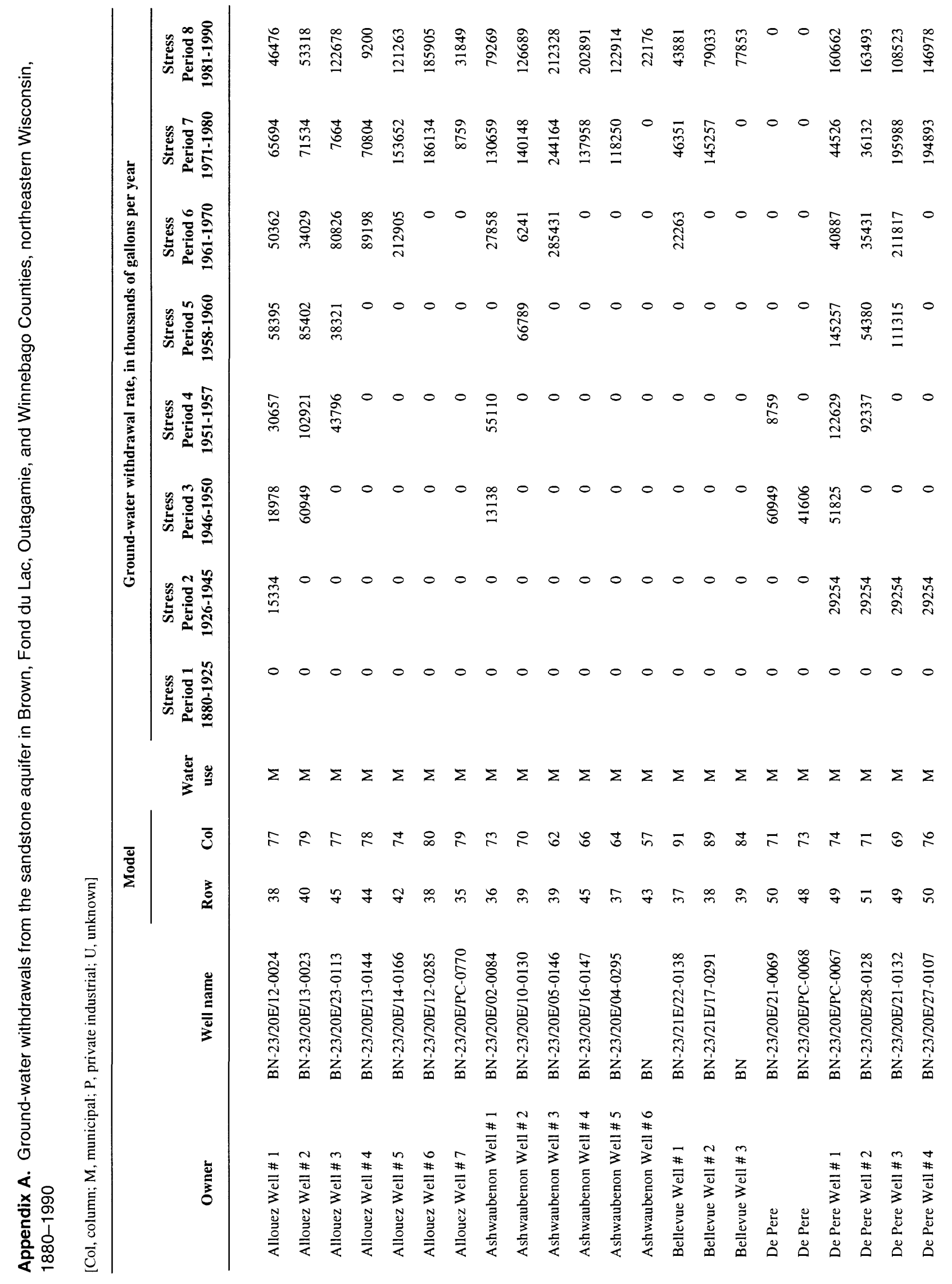




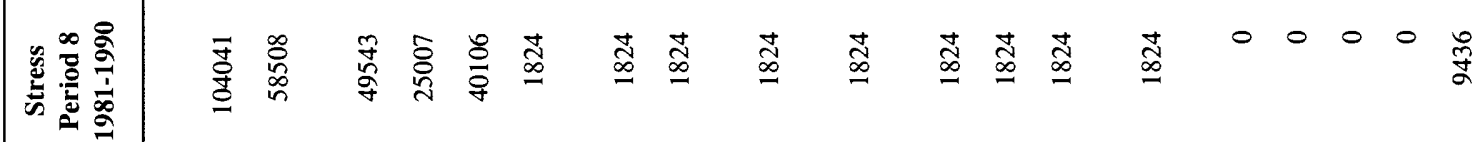

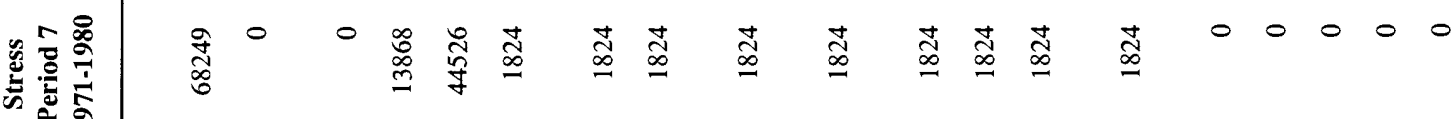

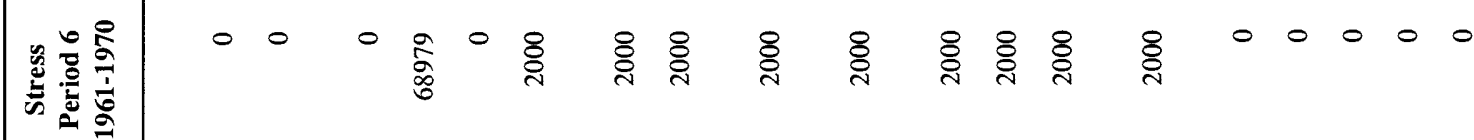

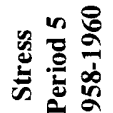
00000000000000000000

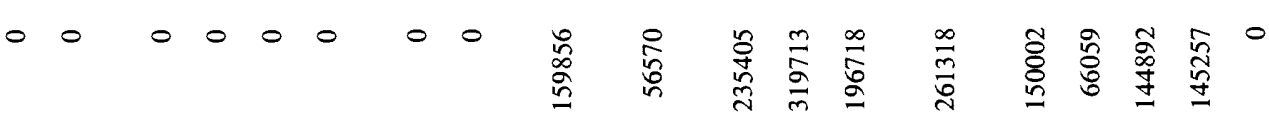

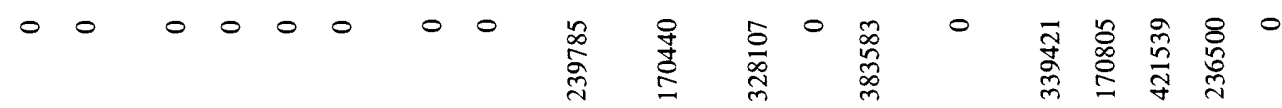

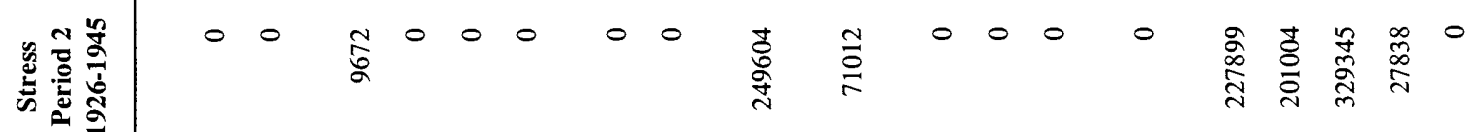

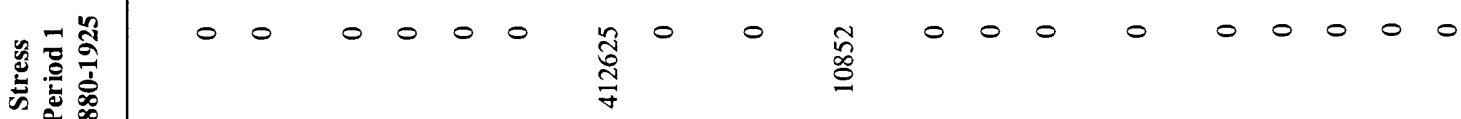

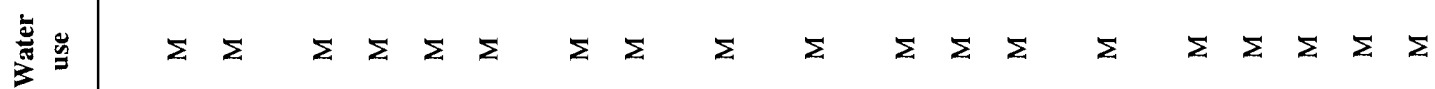

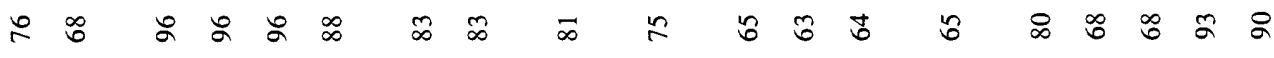
in in in i⿱

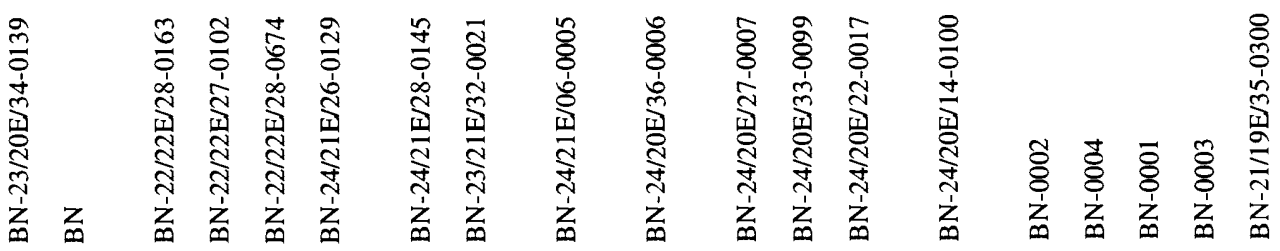

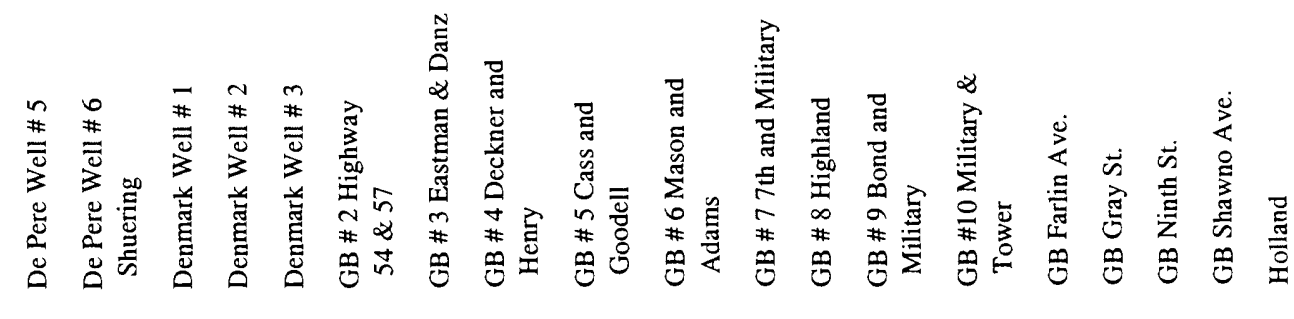




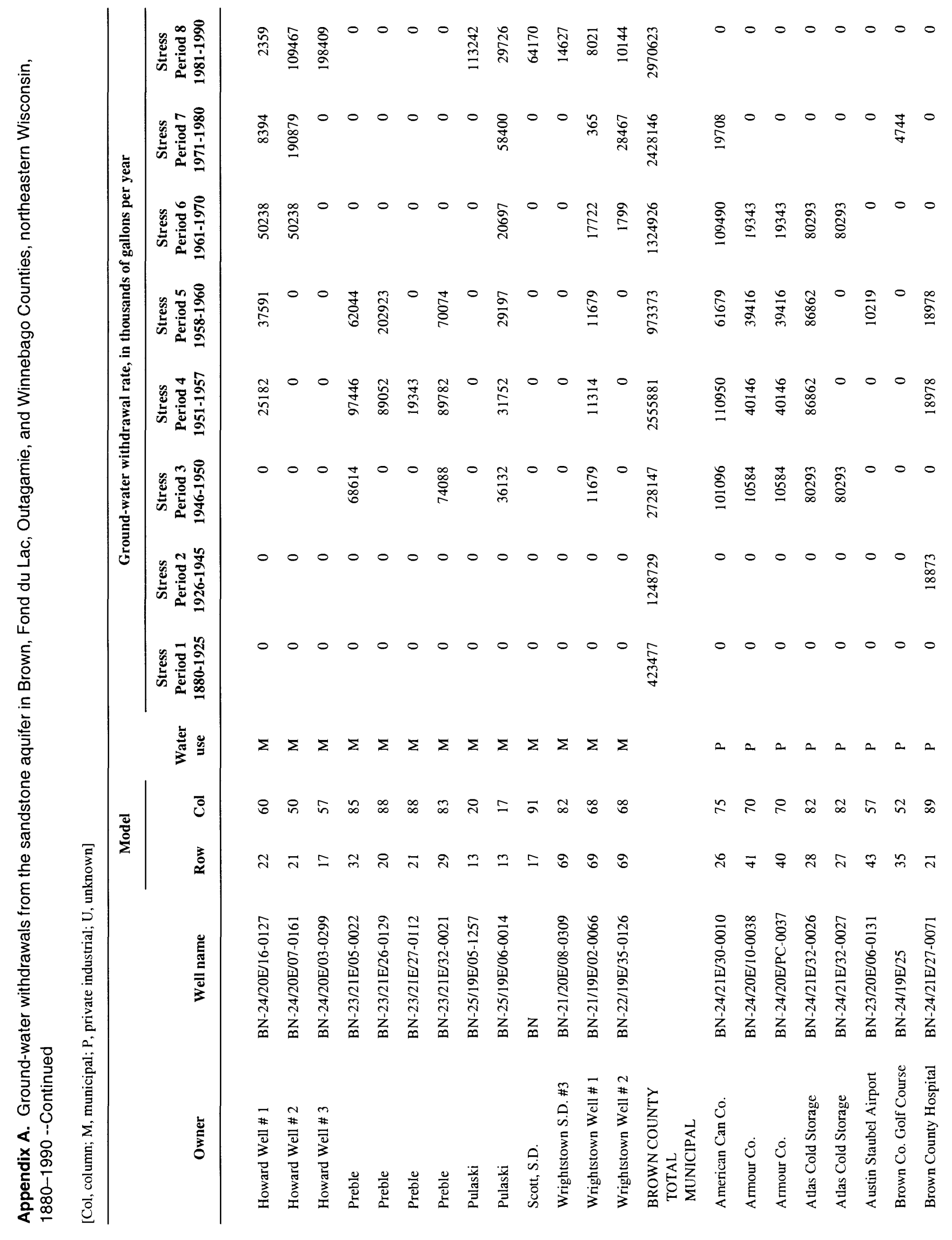




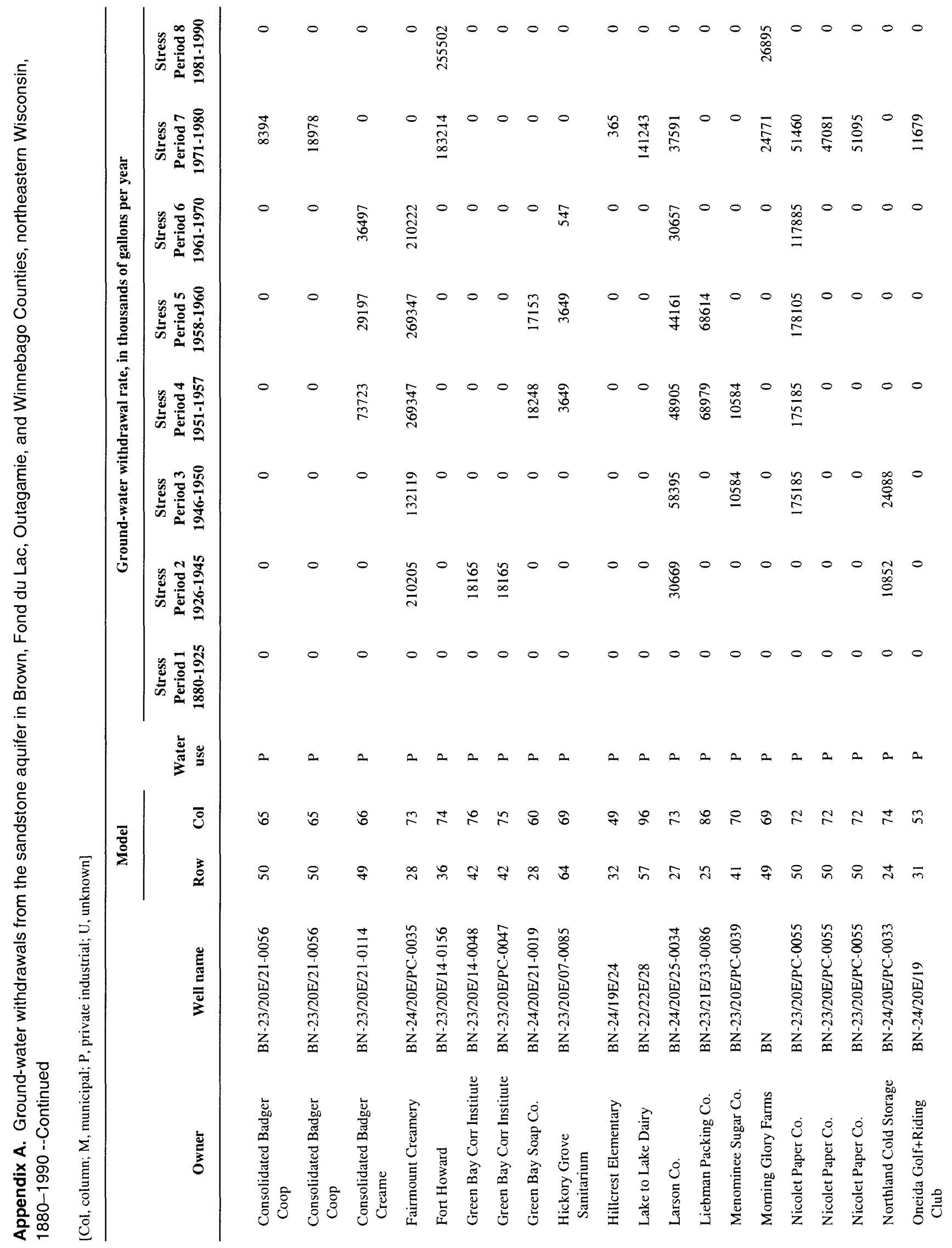




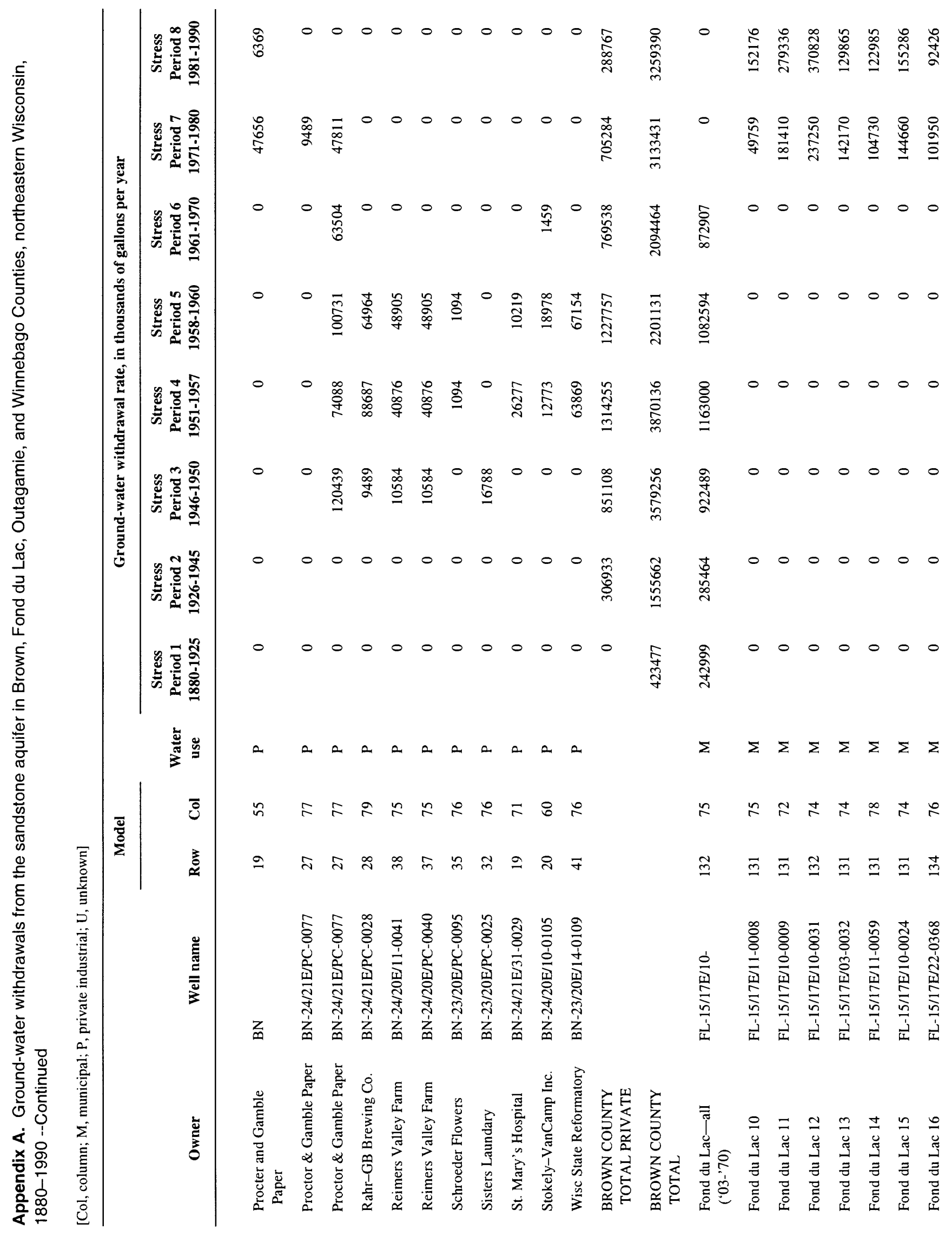




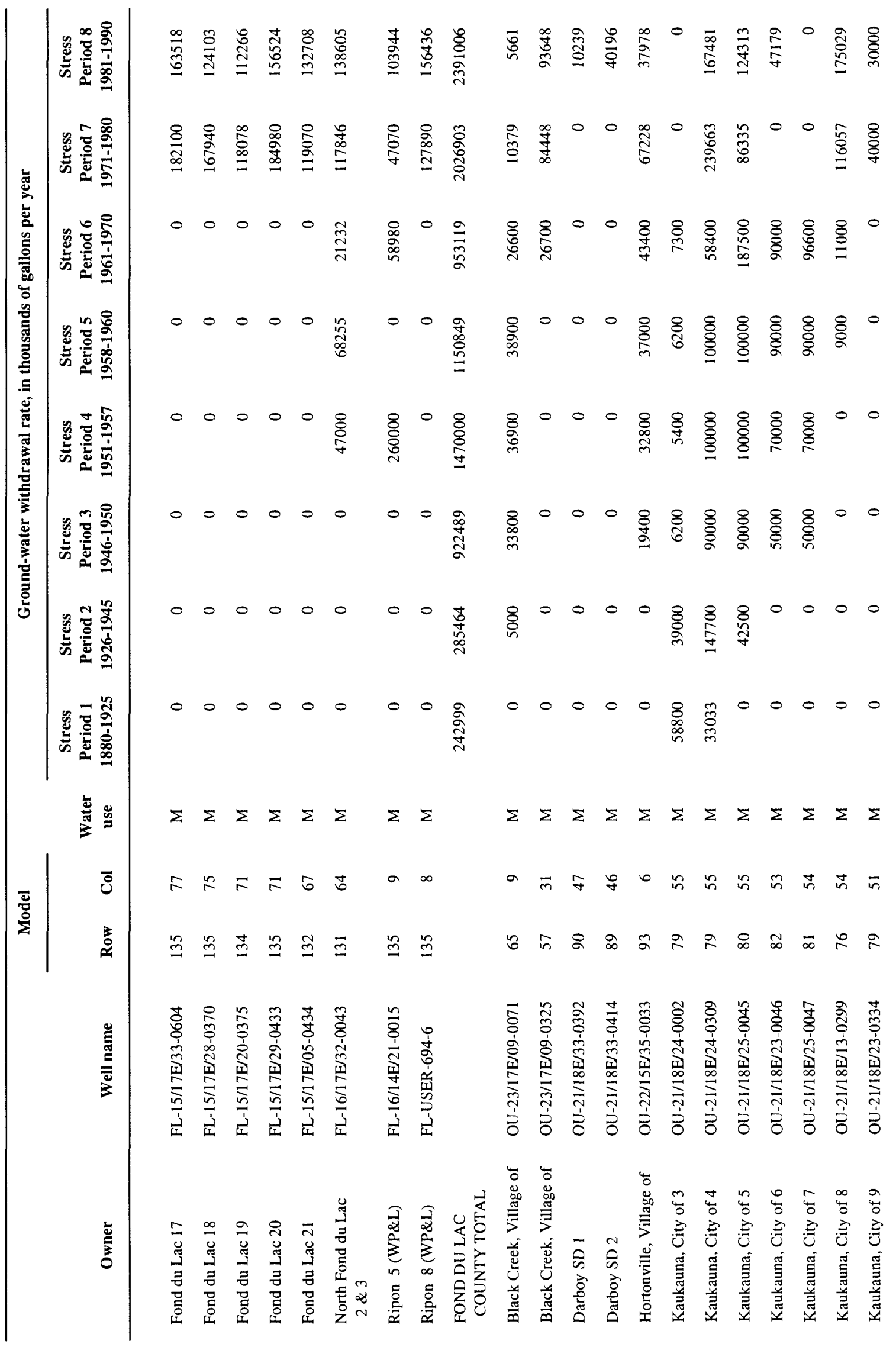




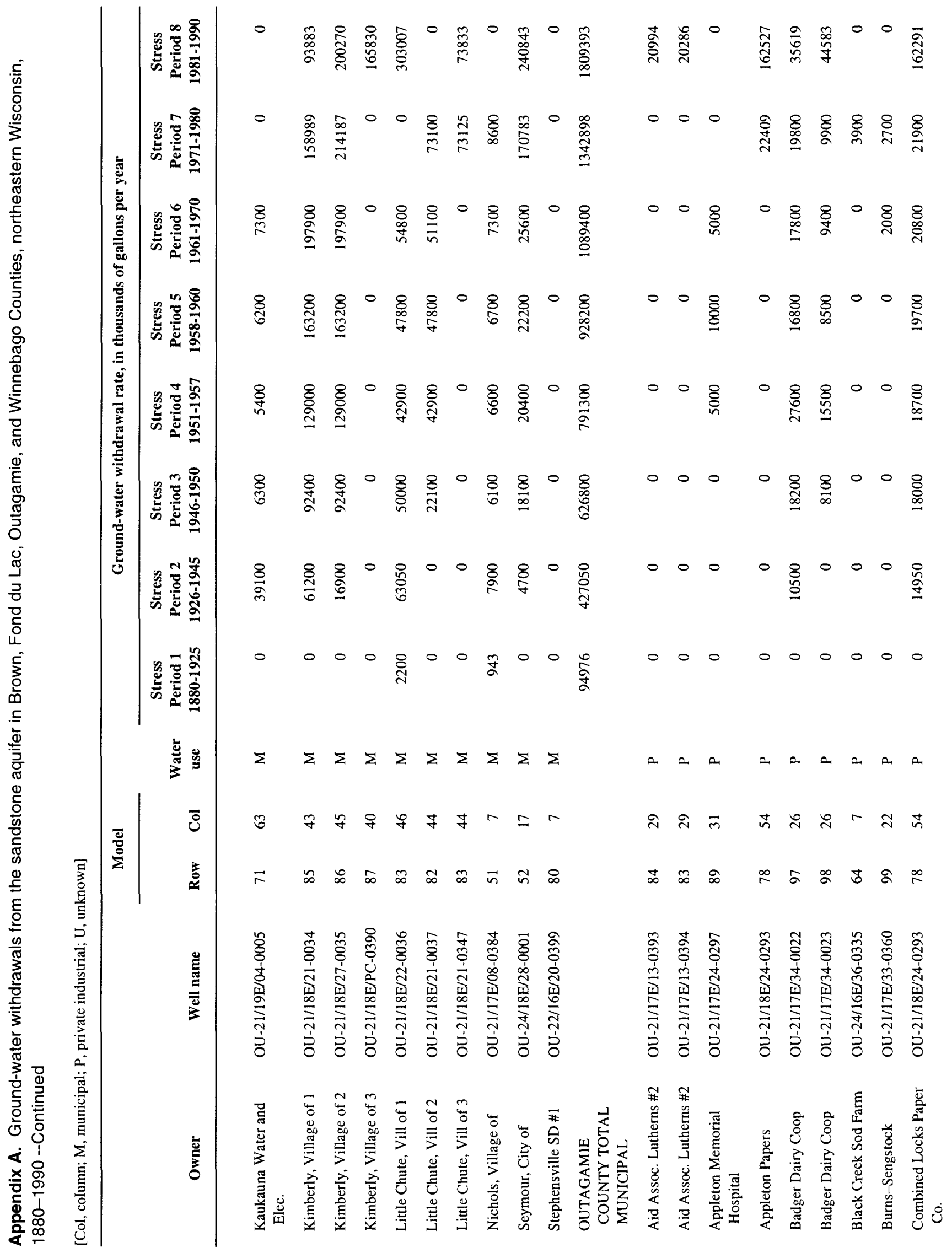




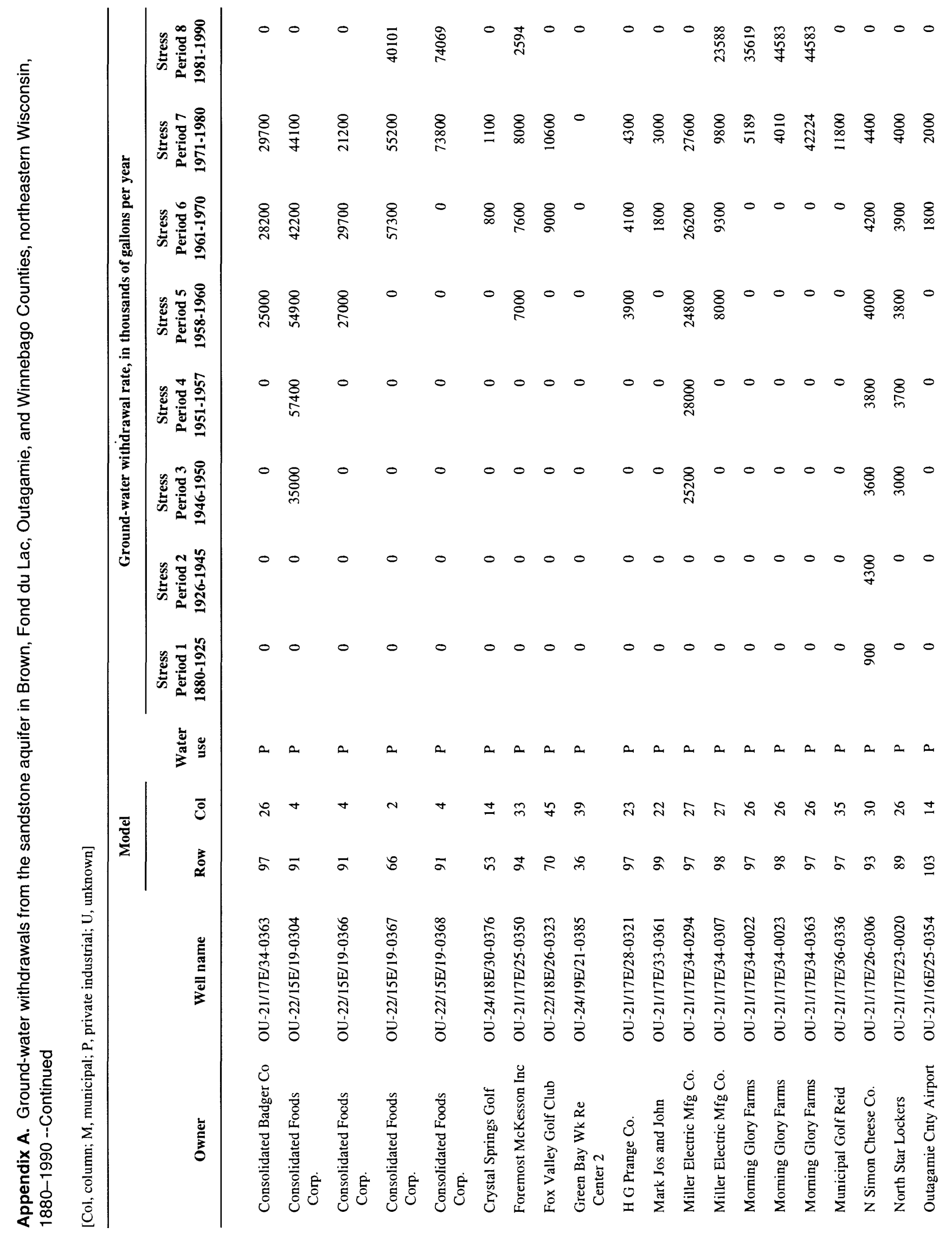




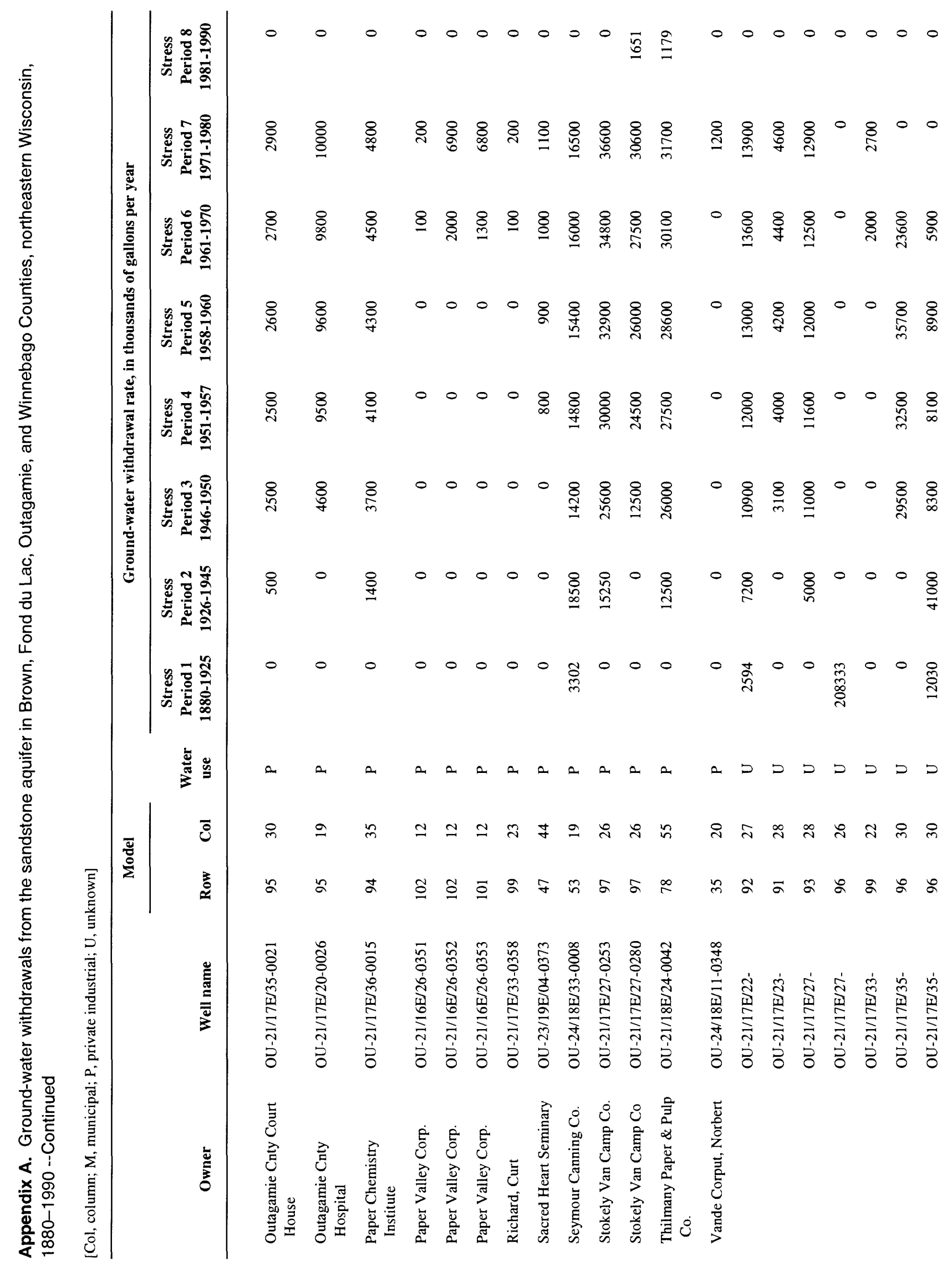




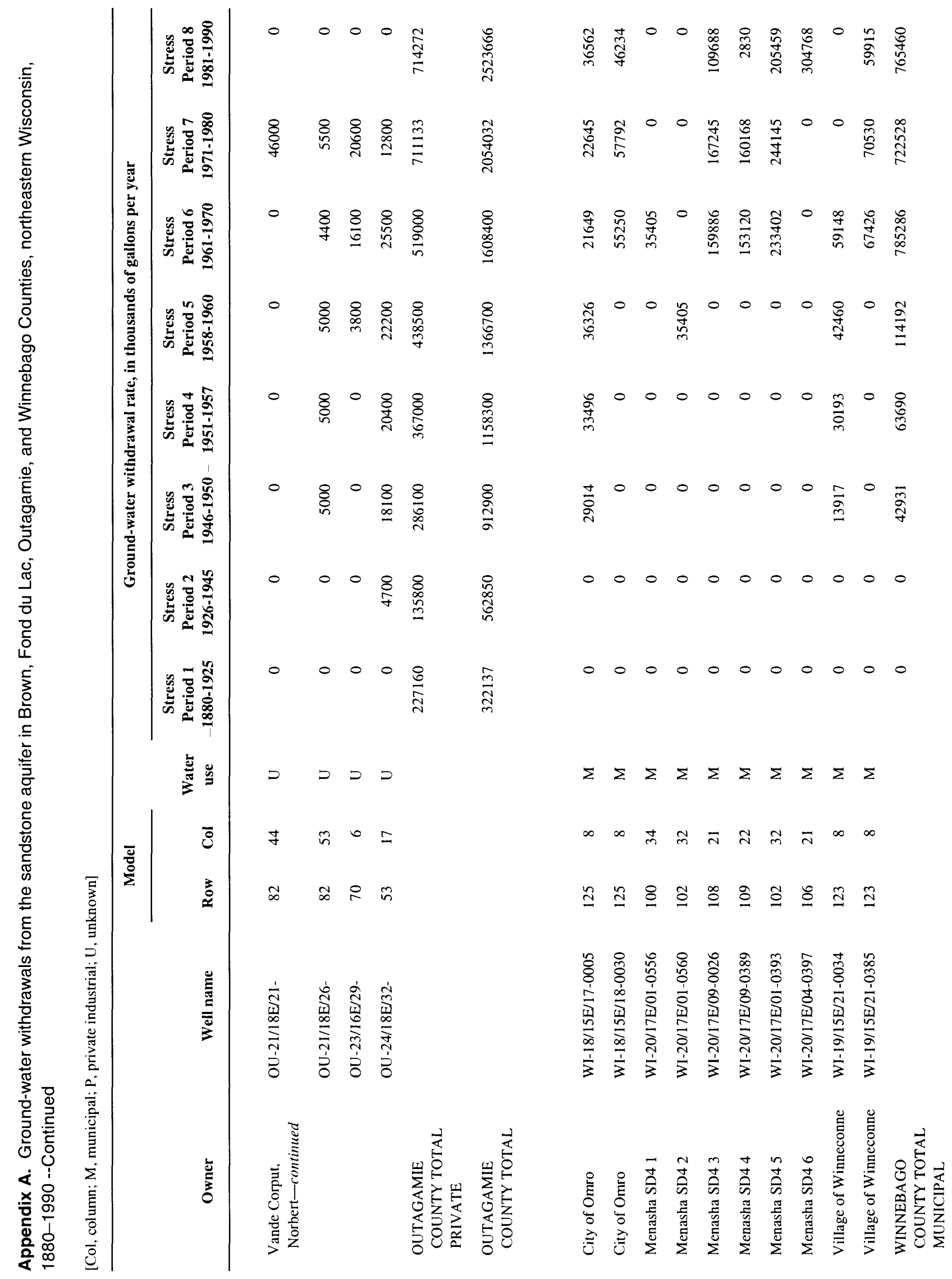




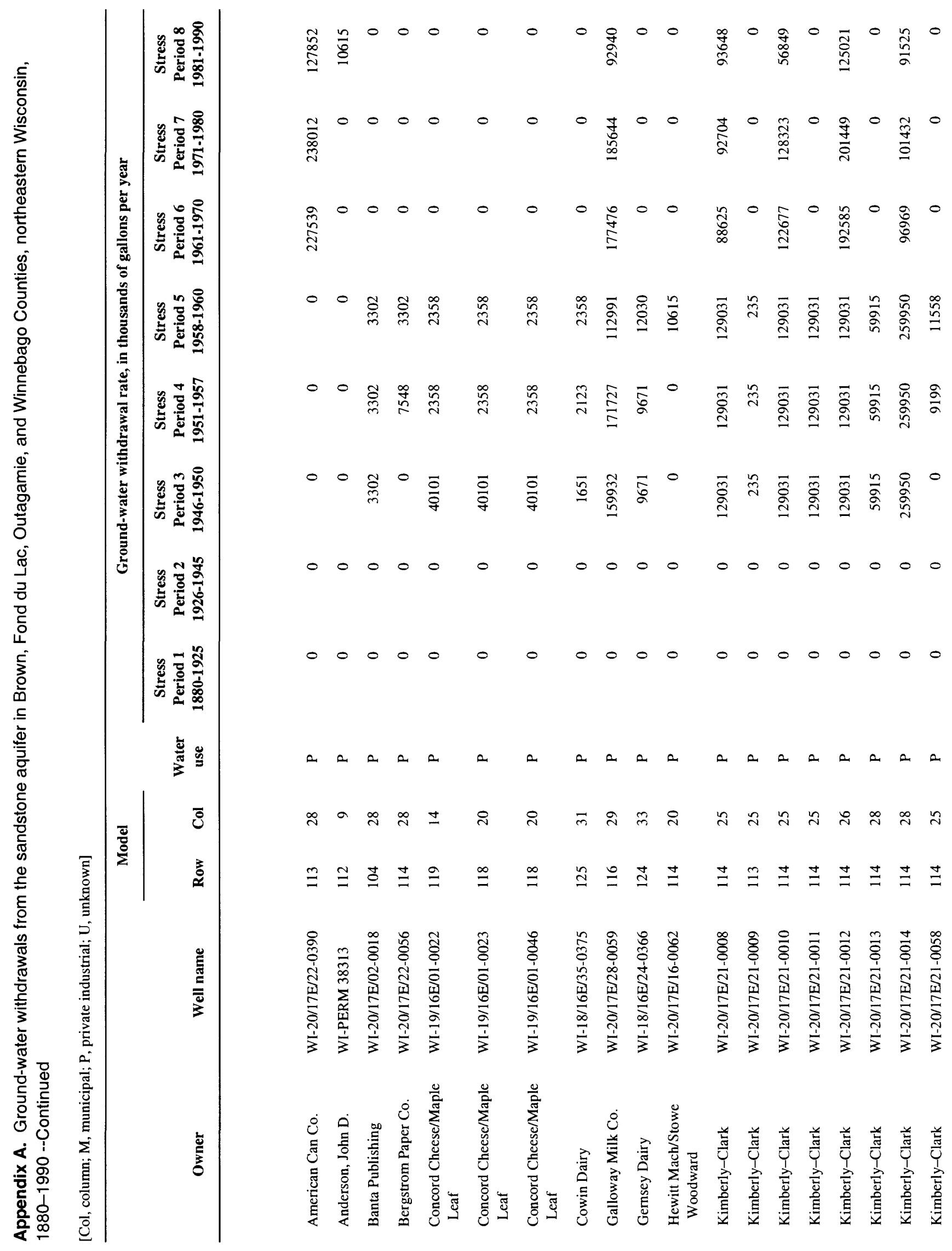




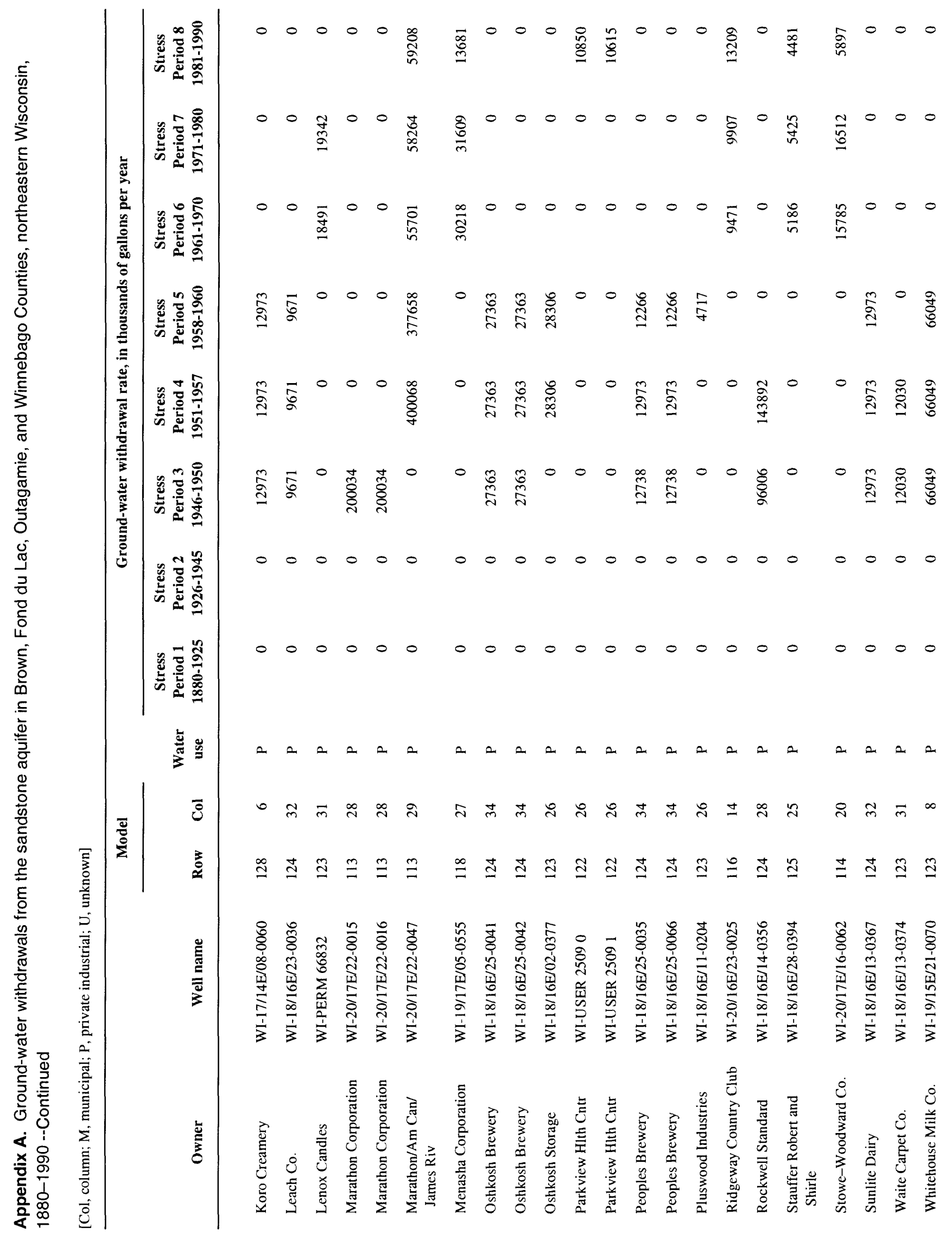




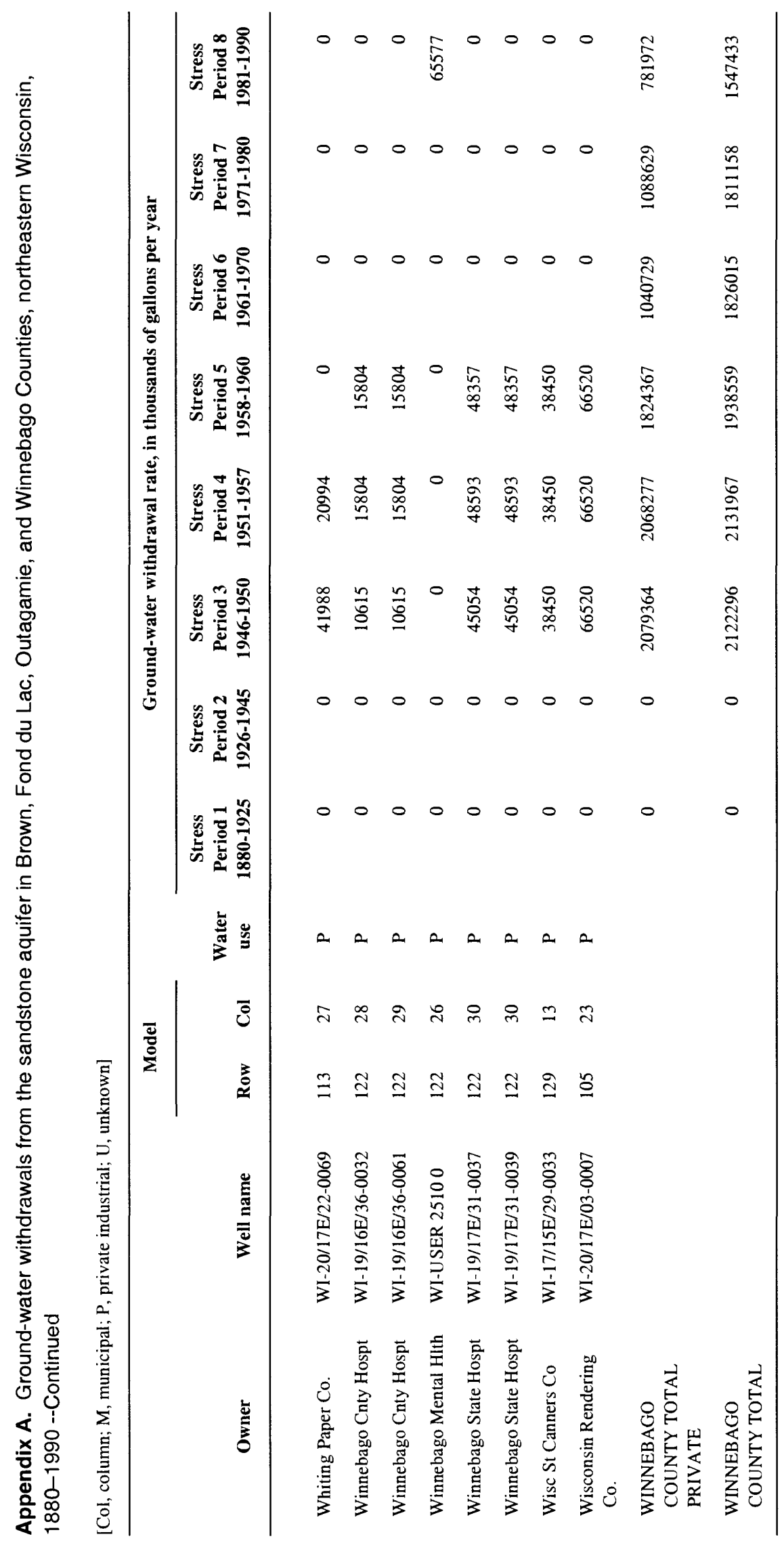

